Phone: 1.703.818.9100

Fax: 1.703 .818 .9108

\title{
DOE/Industrial Technologies Program DOE Award Number DE-FG36-05G015099 Plant Wide Energy Efficiency Assessment Pilgrims Pride Corporation - Mt Pleasant Facility
}

April 13, 2007 


\section{TABLE OF CONTENTS}

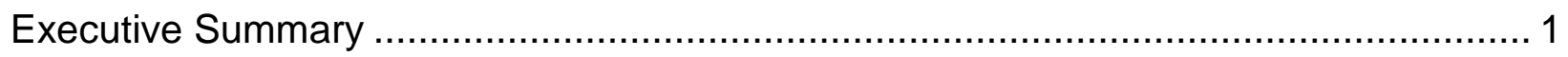

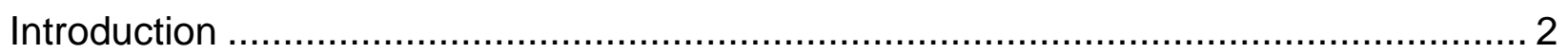

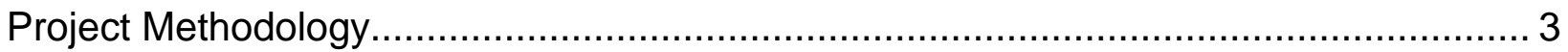

Project Results

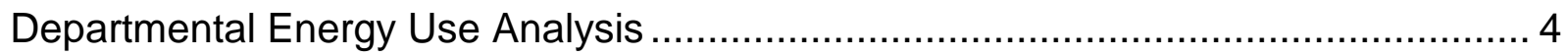

Selection Of Opportunities For Analysis ........................................................... 7

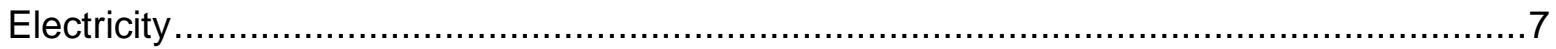

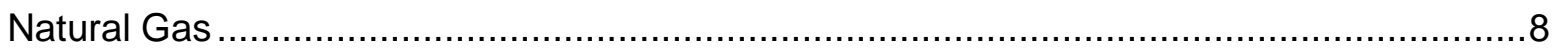

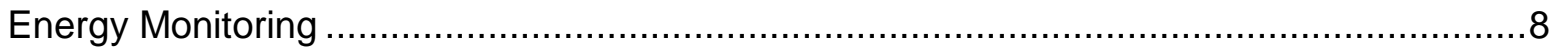

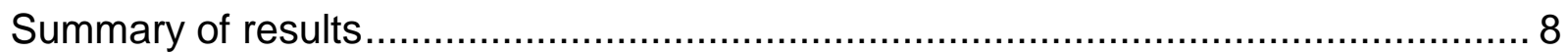

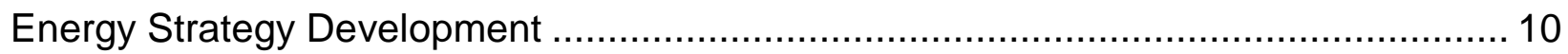

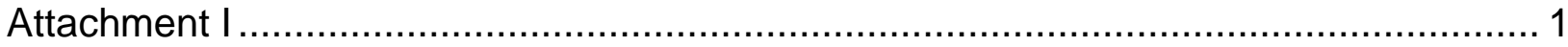

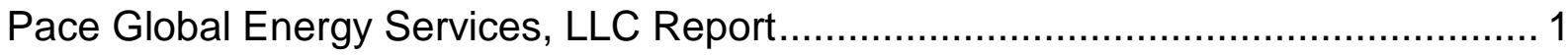

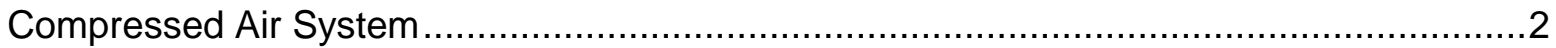

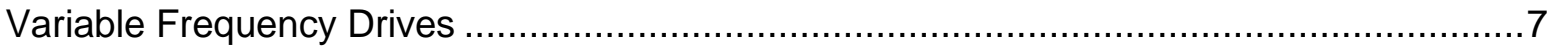

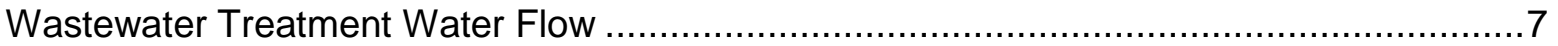

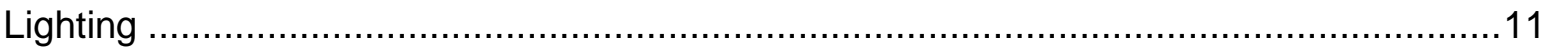

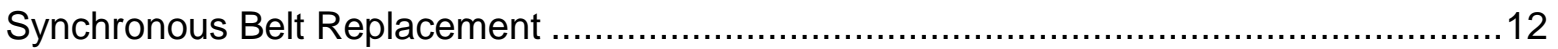

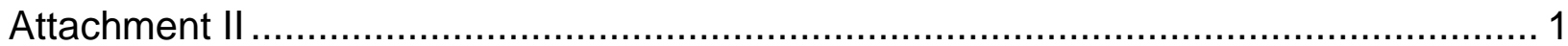

Hudson Technologies Company Final Report .................................................... 1

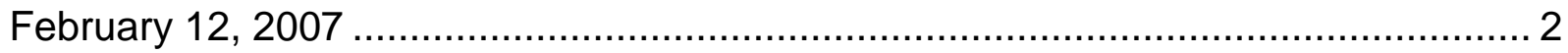

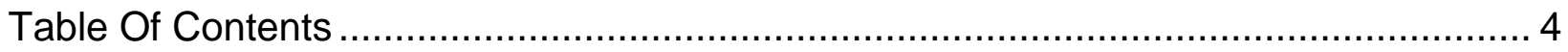

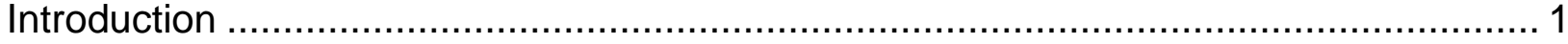

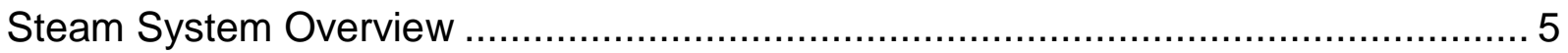

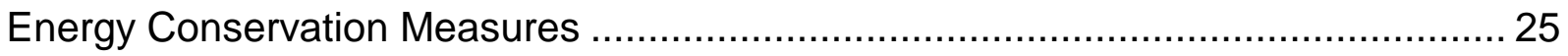

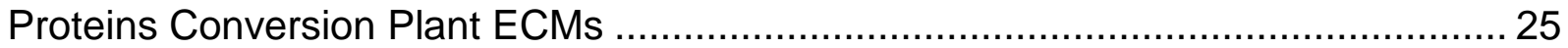

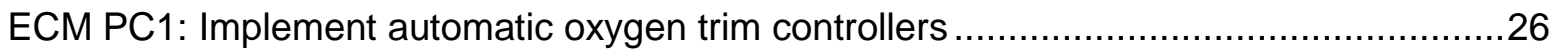

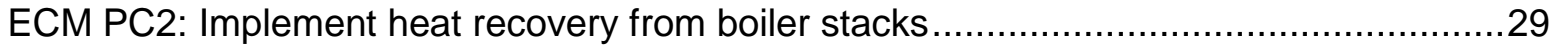

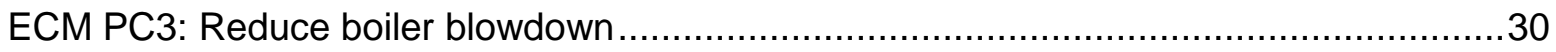

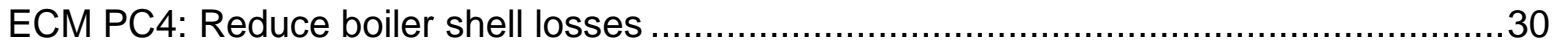

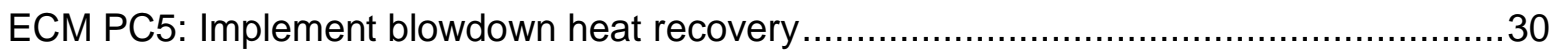

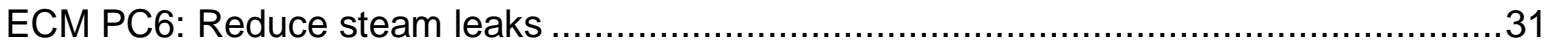

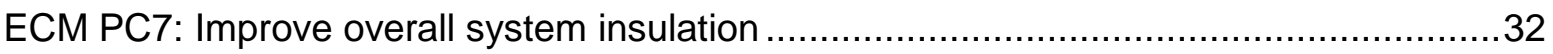

ECM PC8: Improve condensate recovery system....................................................... 
ECM PC9: Flash HP condensate to produce MP steam .............................................. 33

ECM PC10: Preheat cookers B and C feed streams ...................................................

ECM PC11: Install a backpressure steam turbine ................................................ 34

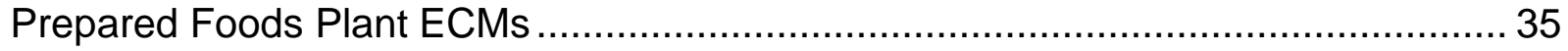

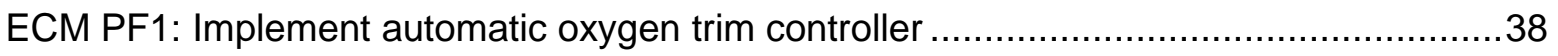

ECM PF2: Implement heat recovery from boiler stack ............................................... 38

ECM PF3: Implement blowdown heat recovery ................................................ 38

ECM PF4: Improve steam system insulation .......................................................... 39

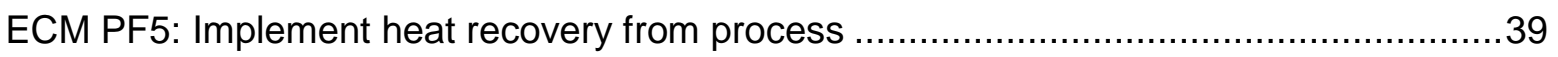

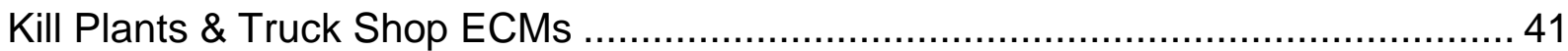

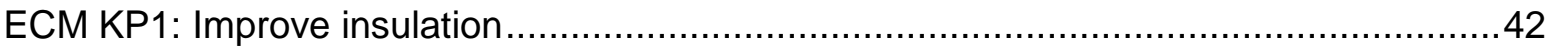

ECM KP2: Implement blowdown heat recovery ................................................. 42

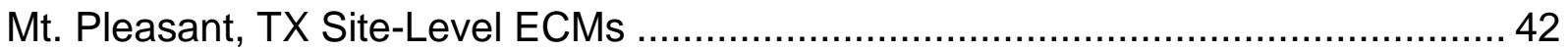

ECM SL1: Centralize steam generation............................................................... 43

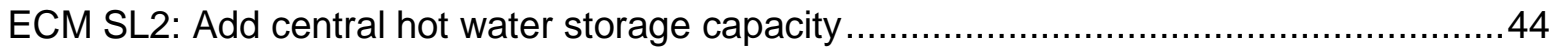

ECM SL3: Reduce overall steam operating pressure ..........................................45

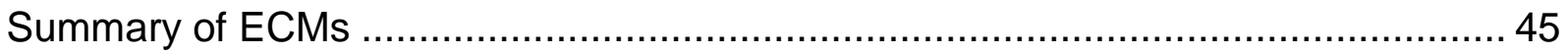

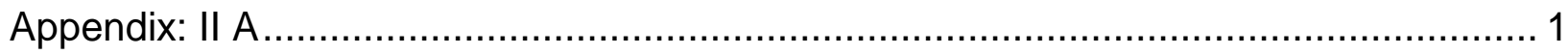

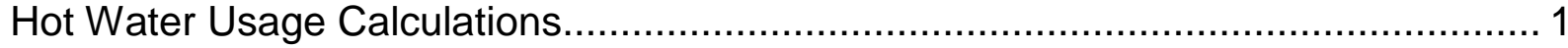

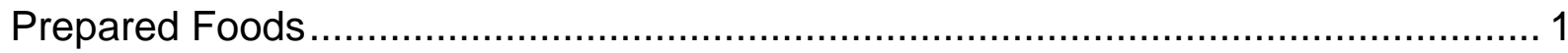

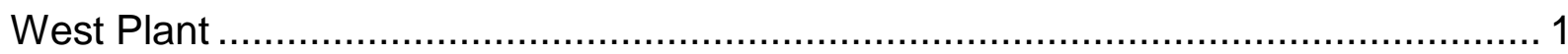

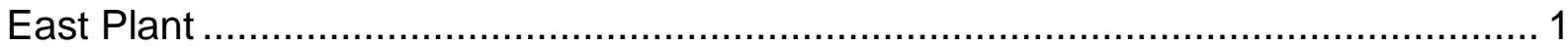

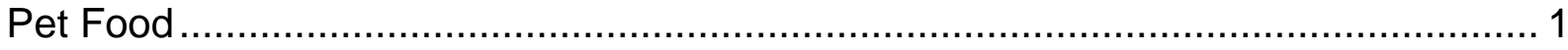

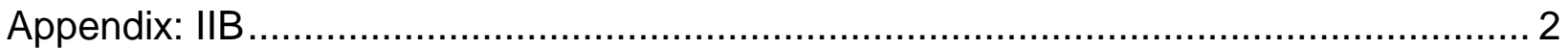

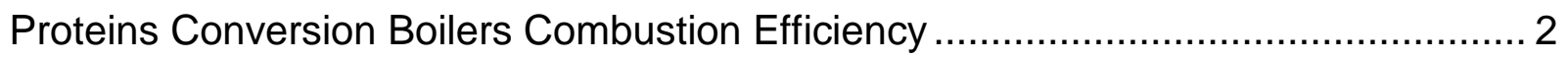

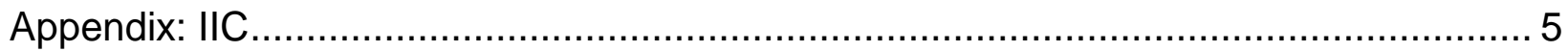

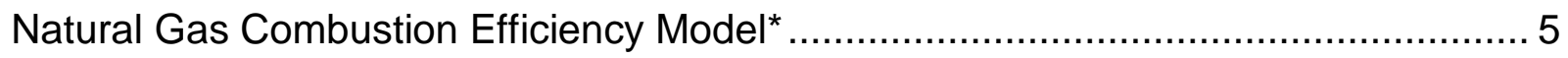

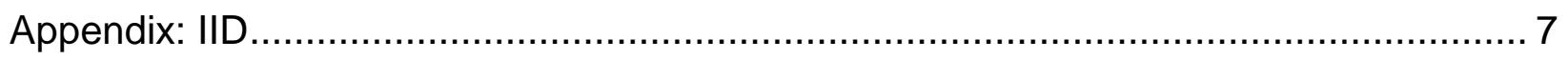

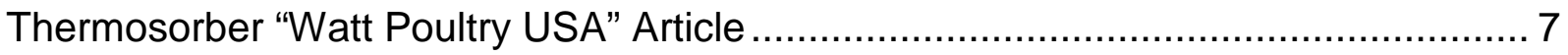

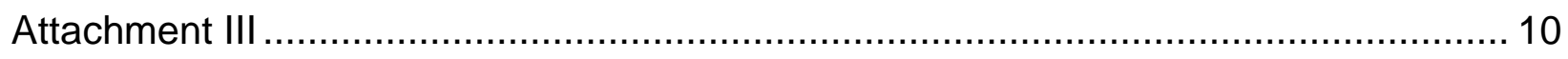

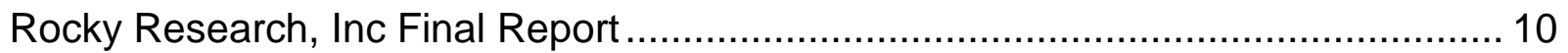

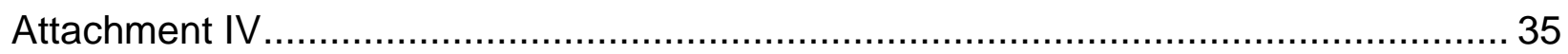

W.J. Turpish And Associates Final Report ............................................. 35

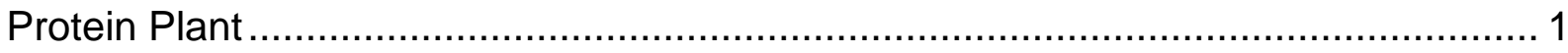

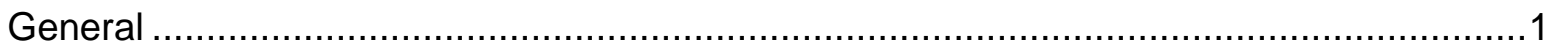

Cooling Tower System-Overview ...................................................................... 


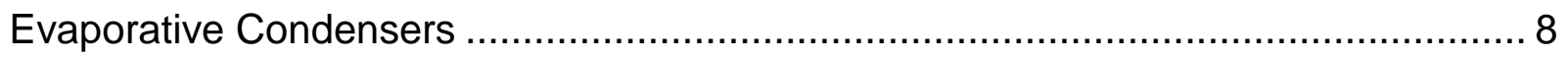

East Plant

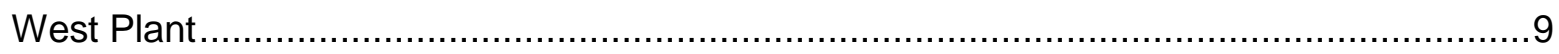

Prepared Foods.

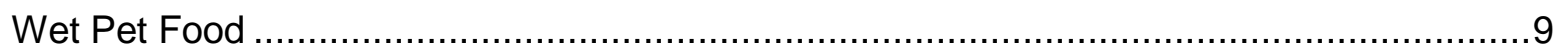

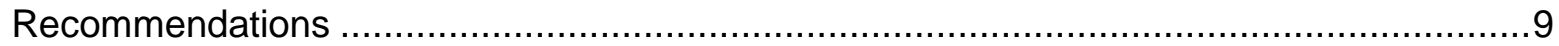




\section{EXHIBITS}

Exhibit 1: Summary of Savings Opportunities by Major System .......................... 1

Exhibit 2: Average Monthly Electricity Consumption by Area .............................. 5

Exhibit 3: Average Monthly Demand by Area .............................................. 5

Exhibit 4: Annual Natural Gas Consumption by Area ........................................ 6

Exhibit 5: Large Energy Consumers by End User ........................................ 6

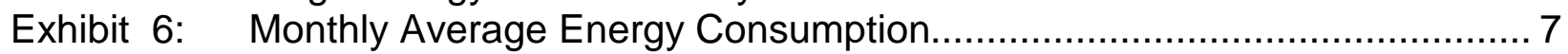

Exhibit 7: Project Summary Table ................................................................. 9

Exhibit 8: $\quad$ Variable Frequency Drive Applications .......................................... 7

Exhibit 9: $\quad$ Current Waste Water Configuration ............................................... 8

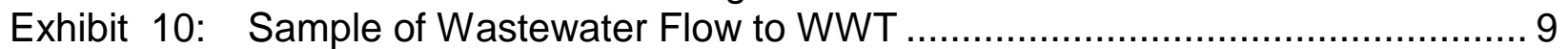

Exhibit 11: Recommended Waste Water System Configuration.......................... 10

Exhibit 12: Comparison of Lighting Systems ............................................. 12 


\section{EXECUTIVE SUMMARY}

The U. S. Department of Energy's (DOE) Industrial Technologies Program (ITP), through Oak Ridge National Laboratory, is supporting plant wide energy efficiency assessments that will lead to substantial improvements in industrial efficiency, waste reduction, productivity, and global competitiveness in industries identified in ITP's Industries of the Future. The stated goal of the assessments is to develop a comprehensive strategy at manufacturing locations that will significantly increase plant productivity, profitability, and energy efficiency, and reduce environmental emissions. ITP awarded a contract to Pilgrim's Pride Corporation to conduct a plant wide energy efficiency assessment for their Mt Pleasant Facility in Mt Pleasant, Texas.

Pilgrim's Pride formed a team to complete the plant wide energy efficiency assessment. The scope of work for this project was to:

- provide the analysis of departmental energy use

- identify areas for detailed analysis

- perform a detailed analysis for several of the opportunities identified

- and support the development of an energy strategy for the facility.

The team consisted of Pace Global Energy Services, LLC; Hudson Technologies Company; Rocky Research, Inc.; and W.J. Turpish and Associates.

The project used a systematic approach to complete a plant-wide energy efficiency assessment at the Mt Pleasant Facility. Major energy consuming equipment and processes were determined and opportunities for high annual savings potential were targeted for further evaluation. Exhibit 1 below summarizes the major savings opportunities at the site. The total energy savings represent $14 \%$ of the energy consumed on site on an MMBtu basis, with $12 \%$ of total energy savings achievable in projects with less than a two year payback.

\section{Exhibit 1: Summary of Savings Opportunities by Major System}

\begin{tabular}{|l|r|r|}
\hline Savings Opportunity & Annual Savings & Capital Cost \\
\hline Thermal System Efficiency & $\$ 1,643,000$ & $\$ 1,898,000$ \\
\hline Waste Heat Recovery & $\$ 1,041,000$ & $\$ 1,155,000$ \\
\hline Refrigeration Systems & $\$ 129,000$ & $\$ 277,000$ \\
\hline Compressed Air System Improvements & $\$ 22,400$ & $\$ 69,500$ \\
\hline Pumps and Motors & $\$ 226,000$ & $\$ 393,900$ \\
\hline Wastewater Treatment Process & $\$ 72,500$ & $\$ 100,000$ \\
\hline Lighting & $\$ 9,600$ & $\$ 36,700$ \\
\hline Total & $\$ 3,143,500$ & $\$ 3,930,100$ \\
\hline
\end{tabular}




\section{INTRODUCTION}

The U. S. Department of Energy's (DOE) Industrial Technologies Program (ITP), through Oak Ridge National Laboratory, is supporting plant wide energy efficiency assessments that will lead to substantial improvements in industrial efficiency, waste reduction, productivity, and global competitiveness in industries identified in ITP's Industries of the Future. The stated goal of the assessments is to develop a comprehensive strategy at manufacturing locations that will significantly increase plant productivity, profitability, and energy efficiency, and reduce environmental emissions. This will include the adoption of best available and emerging technologies, and best practices for process systems and plant utilities. ITP awarded a contract to Pilgrim's Pride Corporation to conduct a plant wide energy efficiency assessment for their Mt Pleasant Facility in Mt Pleasant, Texas.

Pilgrim's Pride Corporation is the largest poultry company in the U.S. and Mexico producing nearly 9 billion pounds of poultry per year. Pilgrim's Pride products are sold to foodservice, retail and frozen entrée customers. Pilgrim's Pride owns and operates 37 chicken processing plants (34 in the U.S. and three in Mexico), 12 prepared foods plants and one turkey processing plant. Thirty-five feed mills and 49 hatcheries support these plants. Pilgrim's Pride is ranked number 382 on 2006's FORTUNE 500 list and net sales were $\$ 7.4$ billion.

In Mt. Pleasant, Texas, Pilgrim's Pride operates one of the largest prepared foods plants in the United States, with the capability of producing 2,000 different products and the capacity to turn out more than 7 million pounds of finished goods per week. The facility is divided into distinct departments: East Kill, West Kill, Prepared Foods, Protein Conversion, Wastewater Treatment, and Truck Shop. Facility processes include killing, eviscerating, refrigeration, baking, frying, and protein conversion.

Pilgrim's Pride formed a team to complete the plant wide energy efficiency assessment. The scope of work for this project was to:

- provide the analysis of departmental energy use

- identify areas for detailed analysis

- perform a detailed analysis for several of the opportunities identified

- and support the development of an energy strategy for the facility.

The team consisted of Pace Global Energy Services, LLC; Hudson Technologies Company; Rocky Research, Inc.; and W.J. Turpish and Associates.

Pace Global Energy Services, LLC of Fairfax, Virginia provided the analysis of departmental energy use, identification of areas for detailed analysis, and support for the development of an energy strategy for the facility. Hudson Technologies Company analyzed the combustion and steam systems to identify opportunities for economic heat recovery and improvement in boiler operations. Rocky Research, Inc analyzed the refrigeration systems and W.J. Turpish and Associates reviewed the cooling towers and evaporative condensers. 


\section{PROJECT METHODOLOGY}

Pilgrim's Pride provided overall project direction, as well as on-site resources for data collection and analysis. The project used a systematic approach to complete a plant-wide energy efficiency assessment at the Mt. Pleasant facility. Energy use for each manufacturing process was determined. Processes with high annual savings potential were targeted for further evaluation. Targeted processes were reviewed to quantify potential energy savings and estimate required capital costs. While a preliminary walk-through assessment identified several areas with savings potential, a systematic approach ensured that a significant savings opportunity was not overlooked.

Upon completion of above evaluation analysis, the identified cost-effective opportunities were gathered and a comprehensive plant-wide energy reduction strategy developed. The strategy includes a tiered approach to project implementation to take advantage of low cost/high payback opportunities that may be replicable at other sites. This plan will provide key data to support capital budgeting activities and transferring knowledge to Pilgrim's Pride operation having similar processes. 


\section{PROJECT RESULTS}

\section{DEPARTMENTAL ENERGY USE ANALYSIS}

Annual fuel and power consumption was collected and then broken down by type of usage to the smallest practical units. Few energy consumers are metered individually and estimates of energy use were required. Energy capacity data was based on nameplate rating: connected load in horsepower or kilowatts for electrical equipment, and heat output for combustion equipment. Load factors were based on observations during the site visit or on plant personnel's experience, estimating the typical percentage of full load the equipment operates at during a typical cycle. The on-stream factors were based on typical operating hours for the equipment. On-stream factors accounted for the number of operating shifts per week, and the percentage of operating hours per shift. For each piece of equipment, annual energy consumption was estimated by multiplying energy capacity by the load factor and the on-stream factor. Estimated energy consumption was summed to determine total estimated plant electric use and fuel use. Load factors and on-stream factors were modified to match estimated energy use to the actual consumption for the period evaluated.

The analysis grouped individual equipment by plant operating areas and equipment type. Plant operating areas were East Kill Plant, West Kill Plant, Prepared Foods, Protein Conversion (Rendering), Wastewater Treatment, and the Truck Shop. Exhibit 2 shows a breakdown of electricity use by area, Exhibit 3 shows the electric demand by area, and Exhibit 4 shows a breakdown of natural gas use by area. 


\section{(e) PACE}

Exhibit 2: $\quad$ Average Monthly Electricity Consumption by Area

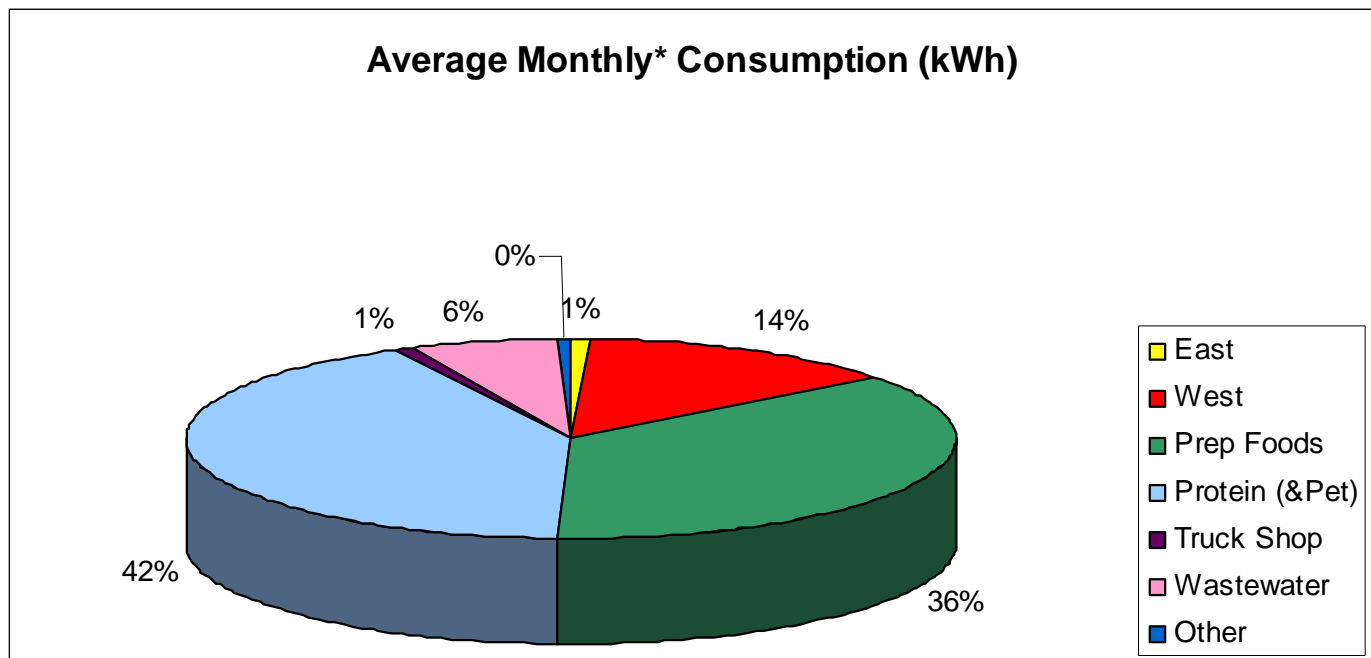

\section{Exhibit 3: Average Monthly Demand by Area}

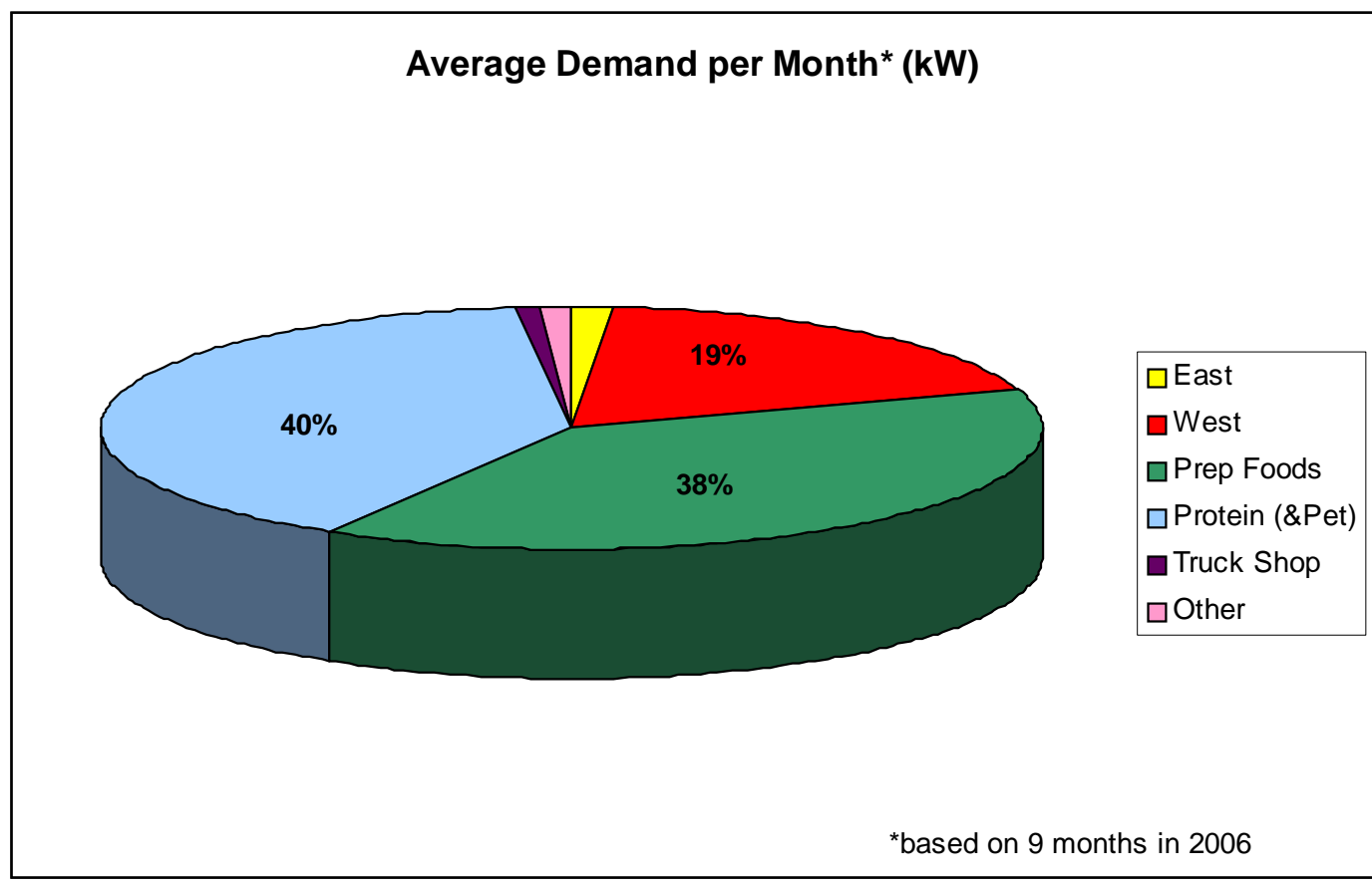




\section{(e) PACE}

Exhibit 4: $\quad$ Annual Natural Gas Consumption by Area

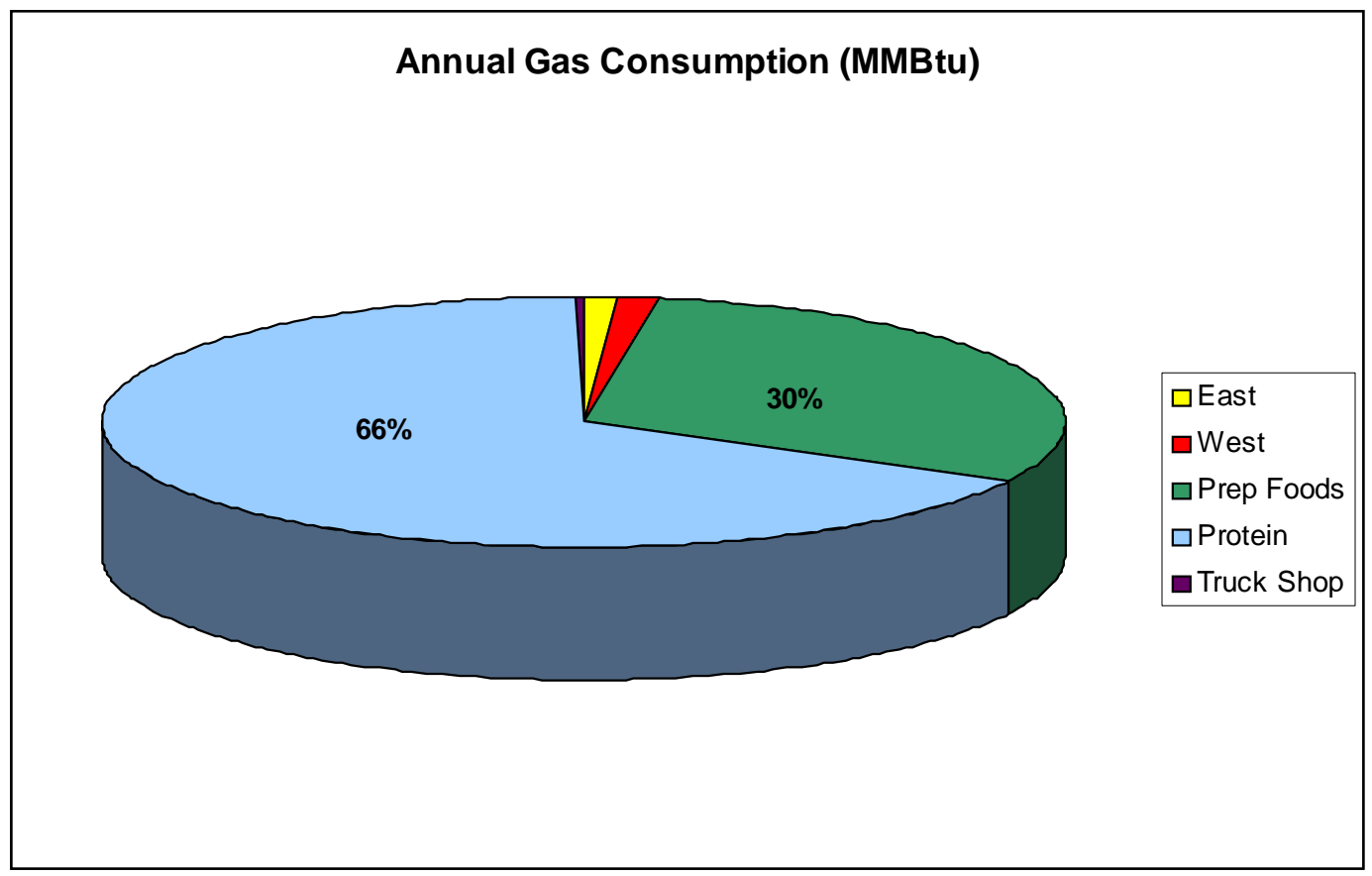

The largest users of energy by end user type at the site are shown in Exhibit 5.

\section{Exhibit 5: Large Energy Consumers by End User}

\begin{tabular}{|l|c|}
\hline Large Energy Consumers & \% of Plant Consumption \\
\hline Electric Demand & $\mathbf{k W}$ \\
\hline Refrigeration Systems (includes Ice Makers) & $37.7 \%$ \\
\hline Process Motors and Pumps (over 30hp) & $21.5 \%$ \\
\hline Wastewater Treatment & $5.0 \%$ \\
\hline Compressed Air & $2.9 \%$ \\
\hline Natural Gas Usage & MMBtu \\
\hline Boilers (Protein Conversion) & $66.7 \%$ \\
\hline Boilers (Kill Plants and Prepared Foods) & $12.6 \%$ \\
\hline Furnaces & $10 \%$ \\
\hline Direct Fired Ovens and Fryers & $8.7 \%$ \\
\hline
\end{tabular}

Exhibit 6 compares the departmental energy use on an MMBtu basis (combines electricity and natural gas). 


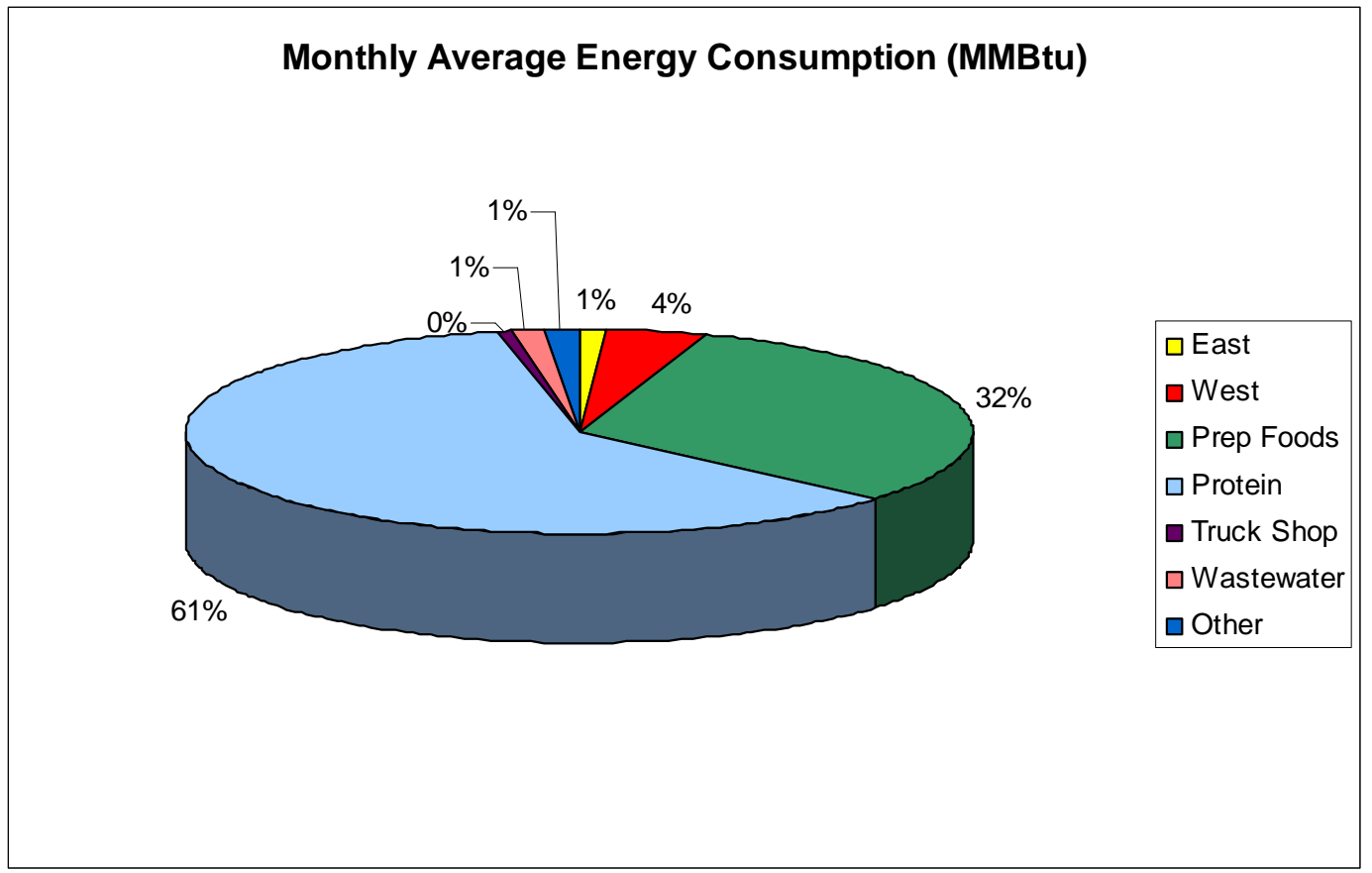

\section{SELECTION OF OPPORTUNITIES FOR ANALYSIS}

The second task of the project was to identify energy reduction opportunities for further in-depth study. Large consumers were evaluated, and potential energy savings were estimated based on plant experience. Projects were selected based on energy consumption and estimated potential for energy savings. The objective was to select projects that had a return on investment within two years, while still including projects with long term benefits to the site. Opportunities for reduced electricity and natural gas consumption were evaluated, as well as site wide opportunities such as cogeneration and energy monitoring.

\section{Electricity}

The following equipment systems were evaluated for reduced electricity consumption:

- Refrigeration Systems

Refrigeration is required for chilling the birds in the kill plants, spiral freezers for the product in Prepared Foods, and space conditioning.

- Compressed Air Systems

Compressed air is used throughout the facility for process equipment as well as a water reuse facility on site.

- Pumps and Motors 
Large motors are used in Protein for rendering processes; pumps are used throughout the facility to move washdown water and waste water.

- Cooling Tower Systems

Provides process cooling for heat exchangers and condensers in the Protein plant..

\section{Natural Gas}

The following equipment systems were evaluated for reduced natural gas consumption and waste heat recovery:

- Steam Boilers

Large boilers in Protein provide the majority of the steam used on site.

- Ovens, Fryers, and Furnaces

Furnaces heat Paratherm for use in indirect fired ovens and fryers; several ovens and fryers are also direct fired.

\section{Energy Monitoring}

Submetering exists on the Mt Pleasant primary electric meter. Plant personnel expressed concern with the accuracy of some of the meters. An effort was made to submeter gas and water as well, but several of these meters are no longer functional and the data was difficult to analyze. Improved energy monitoring would provide a method to benchmark energy use and to insure that efficiency gains realized from this analysis are maintained in the future. Not only would this be beneficial for the production areas, but also within production areas such as refrigeration equipment or direct versus indirect fired production lines.

\section{SUMMARY OF RESULTS}

Exhibit 7 below summarizes the savings opportunities identified and evaluated by Pace Global. Explanations of each opportunity are in the detailed reports included as attachments. Additional opportunities are included in the reports that are not in Exhibit 7; these opportunities require further study or may affect plant processes and should be carefully considered before implementation. The total energy savings in the table below represent $14 \%$ of the Mt. Pleasant annual energy usage on an MMBtu basis. Energy rates used were $\$ 0.0479 / \mathrm{kWh}$ and \$9.37/MMBtu. Annual operating hours used were 6840 for the East and West Kill Plants, 8568 for Prepared Foods, 7344 for Protein, and 7488 for the Truck Shop unless otherwise stated in the attached reports. 


\section{(9) PACE}

\section{Exhibit 7: Project Summary Table}

\begin{tabular}{|c|c|c|c|c|c|c|c|}
\hline OPPORTUNITIES & kWh & $\begin{array}{l}\text { ANNUAL } \\
\text { MMBtu }\end{array}$ & $\begin{array}{l}\text { SAVINGS } \\
\text { MGallons }\end{array}$ & $\$$ & $\begin{array}{c}\text { IMPLEMENTATION } \\
\text { COST }\end{array}$ & $\begin{array}{l}\text { PAYBACK } \\
\text { (YRS) }\end{array}$ & TIER \\
\hline SITE & & & & & & & \\
\hline Reduce Overall Steam Pressure & & 13,867 & & $\$ 130,000$ & $\$ 50,000$ & 0.4 & $4^{\star}$ \\
\hline Centralize Steam Generation & & 2,277 & & $\$ 21,000$ & $\$ 150,000$ & 7.1 & 4 \\
\hline Variable Frequency Drives & $4,267,000$ & & & $\$ 204,000$ & $\$ 377,400$ & 1.9 & 2 \\
\hline Install Synchronous Belts & 468,000 & & & $\$ 22,500$ & $\$ 16,500$ & 0.7 & 1 \\
\hline $\begin{array}{l}\text { Install Zero Loss Drains \& Compressed Air Leak } \\
\text { Maintenance Program }\end{array}$ & 376,000 & & & $\$ 18,000$ & $\$ 36,000$ & 2.0 & 1 \\
\hline $\begin{array}{l}\text { Compressed Air Looping \& Pressure Reduction } \\
\text { PROTEIN }\end{array}$ & 76,000 & & & $\$ 3,600$ & $\$ 31,000$ & 8.6 & 4 \\
\hline Automatic Oxygen Trim Controller & & 10,416 & & $\$ 98,000$ & $\$ 100,000$ & 1.0 & 2 \\
\hline Heat Recovery from Boiler Stack & & 62,270 & & $\$ 584,000$ & $\$ 500,000$ & 0.9 & 2 \\
\hline Reduce Boiler Blowdown & & 4,629 & & $\$ 43,000$ & $\$ 25,000$ & 0.6 & 1 \\
\hline Reduce Boiler Shell Losses & & 1,250 & & $\$ 12,000$ & $\$ 25,000$ & 2.1 & 3 \\
\hline Blowdown Heat Recovery & & 10,416 & & $\$ 98,000$ & $\$ 75,000$ & 0.8 & 2 \\
\hline Reduce Steam Leaks & & 40,500 & & $\$ 380,000$ & $\$ 250,000$ & 0.7 & 2 \\
\hline Improve Steam System Insulation & & 12,960 & & $\$ 122,000$ & $\$ 50,000$ & 0.4 & 1 \\
\hline Improve Condensate Recovery System & & 14,256 & & $\$ 134,000$ & $\$ 200,000$ & 1.5 & 2 \\
\hline Flash HP Condensate to Produce MP Steam & & 18,144 & & $\$ 170,000$ & $\$ 200,000$ & 1.2 & 2 \\
\hline Preheat Cookers B and C & & 47,736 & & $\$ 448,000$ & $\$ 500,000$ & 1.1 & 2 \\
\hline Install Back Pressure Steam Turbines & $1,134,000$ & $-4,629$ & & $\$ 11,000$ & $\$ 88,000$ & 8.0 & 4 \\
\hline Waste Water Reuse in Cooling Tower & & & 117 & $\$ 200,000$ & $\$ 190,000$ & 1.0 & 2 \\
\hline Install discharge water temperature control on & & & & & & & \\
\hline Cooling Tower fans & 419,000 & & & $\$ 20,000$ & $\$ 8,000$ & 0.4 & 1 \\
\hline $\begin{array}{l}\text { Reconfigure Air Compressors in Protein } \\
\text { PREPARED FOODS }\end{array}$ & 12,000 & & & $\$ 800$ & $\$ 2,500$ & 3.1 & 4 \\
\hline $\begin{array}{l}\text { PREPARED FOODS } \\
\text { Automatic Oxygen Trim Controller }\end{array}$ & & 1,655 & & $\$ 15,000$ & $\$ 40,000$ & 2.7 & 3 \\
\hline Heat Recovery from Boiler Stack & & 6,869 & & $\$ 64,000$ & $\$ 150,000$ & 2.3 & 3 \\
\hline Boiler Blowdown Heat Recovery & & 1,123 & & $\$ 10,000$ & $\$ 25,000$ & 2.5 & 3 \\
\hline Improve Steam System Insulation & & 562 & & $\$ 5,000$ & $\$ 10,000$ & 2.0 & 1 \\
\hline Process Heat Recovery (option C) & 421,000 & 28,080 & & $\$ 283,000$ & $\$ 375,000$ & 1.3 & 2 \\
\hline Use Floating Head Pressure Control & $1,202,000$ & & & $\$ 75,000$ & $\$ 200,000$ & 2.7 & 3 \\
\hline Replace lighting in the Box Room & 71,300 & & & $\$ 3,415$ & $\$ 5,200$ & 1.5 & 1 \\
\hline EAST \& WEST & & & & & & & \\
\hline Improve Steam System Insulation & & 455 & & $\$ 4,000$ & $\$ 10,000$ & 2.5 & $1+$ \\
\hline Boiler Blowdown Heat Recovery & & 228 & & $\$ 2,000$ & $\$ 30,000$ & 15.0 & 4 \\
\hline Shutdown Cooler Evaporators During Washdown & 256,000 & & & $\$ 14,000$ & $\$ 0$ & 0.0 & 1 \\
\hline Add Microporcessor Controls to Condenser Fans & 319,000 & & & $\$ 15,250$ & $\$ 20,000$ & 1.3 & 1 \\
\hline Air Balance and Reintroduce Interior/Exterior & & & & & & & \\
\hline Infiltration & 104,000 & & & $\$ 5,000$ & $\$ 10,000$ & $\frac{2.0}{27}$ & 1 \\
\hline Recover Cooling Energy from Wastewater & $\frac{234,000}{38,250}$ & & & $\$ 11,250$ & $\frac{\$ 30,000}{\$ 8000}$ & $\frac{2.7}{4.0}$ & $\frac{3}{4}$ \\
\hline Install VFDs on Condenser Fans in East Plant & $\frac{38,250}{110000}$ & & & $\$ \frac{\$ 2,000}{\$ 8500}$ & $\frac{\$ 8,000}{\$ 17,000}$ & $\frac{4.0}{20}$ & $\frac{4}{1}$ \\
\hline Install Autopurgers on Ice Systems & 110,000 & & & & & 2.0 & 1 \\
\hline Improve Wastewater Flow & $1,330,000$ & & & $\$ 72,500$ & $\$ 100,000$ & 1.4 & 2 \\
\hline TRUCK SHOP & & & & & & & \\
\hline Hibay Lighting Retrofit & 130,000 & & & $\$ 6,200$ & $\$ 31,500$ & 5.1 & 3\$ \\
\hline
\end{tabular}

*Due to complexities involved moved to Tier 4

$\dagger$ While payback exceeds tier 1 setpoint, measure should be considered for immediate implementation

$\ddagger$ While payback exceeds tier 3 setpoint, measure savings are well documented and do not require additional engineering/research 


\section{ENERGY STRATEGY DEVELOPMENT}

With opportunities identified and quantified, the next step it to develop an energy strategy for the facility that will capture the opportunities. A programmatic approach is outlined below.

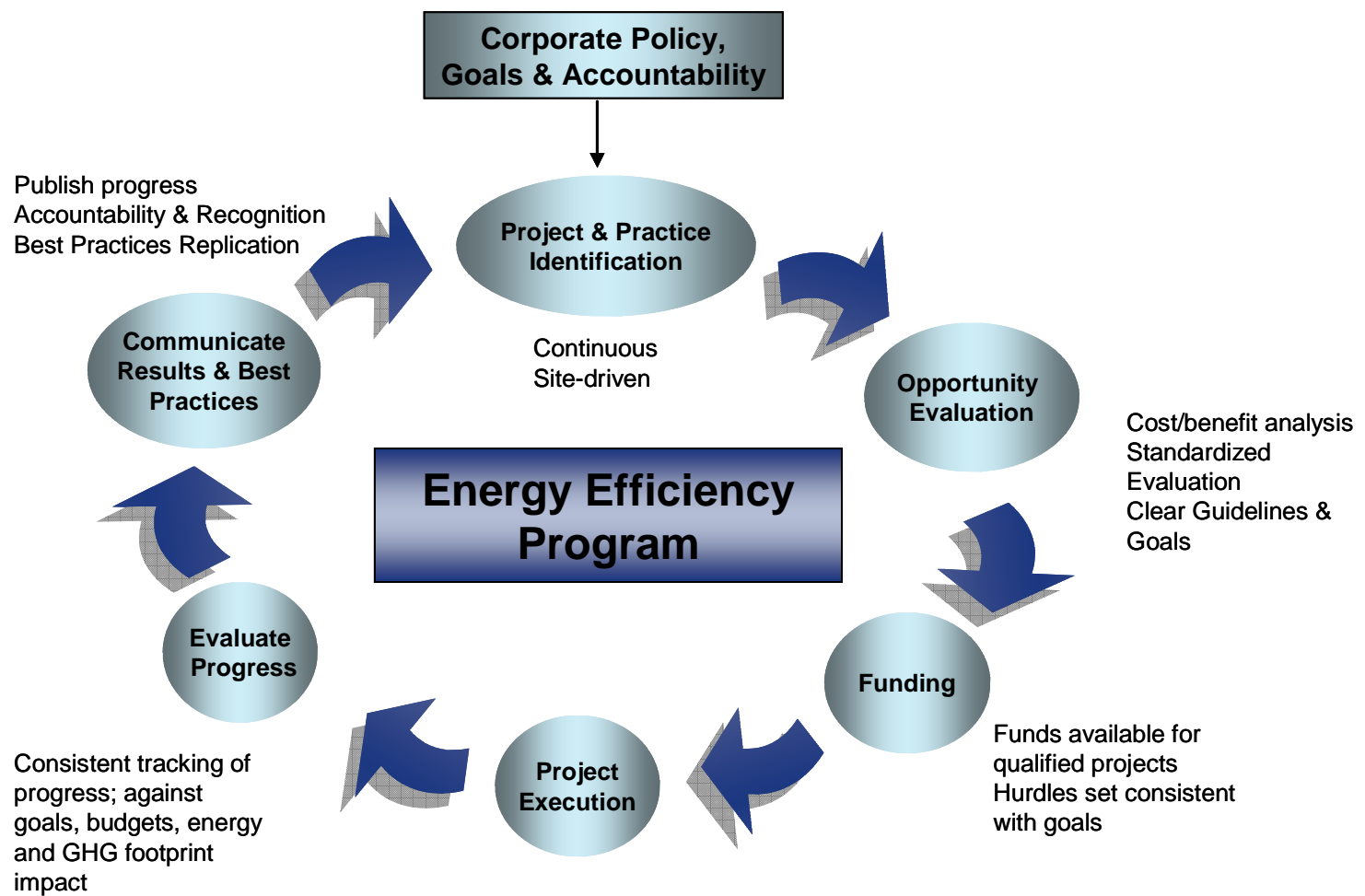

As the number of potential energy efficiency projects is substantial (37 measures), we recommend a "tiered" hierarchy to prioritize their implementation. Tier 1 projects (12 measures) require less than $\$ 50,000$ capital investment and are expected to yield a simple payback of less than 2 years. Tier 2 projects (11 measures) require capital investment of greater than $\$ 50,000$ but also are expected to yield a simple payback of less than 2 years. Tier 3 projects ( 7 measures) are those projects not meeting Tier 1 or 2 criteria that offer a simple ROI of less than 3 years. Tier 4 projects ( 7 measures) are projects with projected payback in excess of 3 years. Not all benefits may be characterized in terms of simple payback, however, and we further recommend Pilgrim's Pride management review and consider all projects in light of potential process and practical benefits.

\begin{tabular}{|l|c|rr|rr|}
\hline Tier & \# of Measures & \multicolumn{2}{|c|}{ Capital Cost } & \multicolumn{2}{|c|}{ Savings } \\
\hline \hline Tier 1 Summary & 12 & $\$$ & 207,700 & $\$ 280,665$ \\
\hline Tier 2 Summary & 11 & $\$ 2,867,400$ & $\$ 2,671,500$ \\
\hline Tier 3 Summary & 7 & $\$$ & 501,500 & $\$$ & 193,450 \\
\hline Tier 4 Summary & 7 & $\$$ & 359,500 & $\$$ & 170,400 \\
\hline
\end{tabular}


Tier 1 Projects:

Install Synchronous Belts

Reduce Boiler Blowdown (Protein)

Improve Steam System Insulation (Protein, Prepared Foods, East and West Kill)

Install Discharge Water Temperature Control

Replace Lighting in the Box Room

Shutdown Cooler Evaporators During Washdown

Add Microprocessor Controls to Condenser Fans

Air Balance and Reintroduce Interior/Exterior Infiltration

Install Autopurgers on Ice Systems

Tier 2 Projects

Variable Frequency Drives

Automatic Oxygen Trim Controllers (Protein)

Heat Recovery from Boiler Stack (Protein)

Blowdown Heat Recovery (Protein)

Reduce Steam Leaks (Protein)

Improve Condensate Recovery System

Flash HP Condensate to Produce MP Steam

Preheat Cookers B and C

Waste Water Reuse in Cooling Towers

Process Heat Recovery (Option C)

Improve Wastewater Flow

Tier 3 Projects

Reduce Boiler Shell Losses

Automatic Oxygen Trim Controller (Prepared Foods)

Heat Recovery from Boiler Stack (Prepared Foods)

Use Floating Head Pressure Control

Recover Cooling Energy from Wastewater

Hibay Lighting Retrofit

Tier 4 Projects

Reduce Overall Steam System Pressure

Centralize Steam System Generation

Compressed Air Looping and Pressure Reduction

Reconfigure Air Compressors in Protein

Boiler Blowdown Heat Recovery (East and West Kill)

Install VFDs on Condenser Fans (East Kill)

We believe this assessment to have captured the vast majority of significant energy efficiency opportunities suitable for replication within the Pilgrim's Pride facilities. Nonetheless, other like facilities may benefit from a structured assessment of similar processes and applications. 
Pilgrim's has completed Site Visits at 11 of their 12 targeted locations. Several important themes emerged through the Site Visit process:

- Heat recovery / boiler optimization

- Compressed air system design \& leak detection

- Power factor improvement

- Contract negotiations and vendor relationships

- Refrigeration

These important themes, along with those in the Natchitoches DOE Survey and those in this DOE plant-wide energy efficiency assessment at Mt Pleasant, mutually reinforce one another and underpin why we believe it is important to re-invigorate the Utilities Utilization Strategic Synergies Team $(\mathrm{SST})^{1}$.

Following the Site Visits and the Plant-wide Energy Efficiency Assessment in Mt Pleasant, the energy infrastructure at 13 of Pilgrim's largest complexes will be understood. The Energy Team will then work together to determine which projects require further assessment and which projects are ready for implementation. We believe this understanding and the opportunities identified will serve as a key motivator to re-energize the Utilities Utilization SST, which will be tasked with implementing identified opportunities, replicating them, proselytizing efficiency and identifying new opportunities.

1 A Strategic Synergy Team ("SST") is a cross-functional team with senior executive champions established to identify and deploy efficiencies within a defined scope of the operation. Alternative Energy and Utilities Utilization, also known as energy efficiency, are SSTs that the Energy Team has or seeks a lead role in, respectively. 
(e) PACE

PACE GLOBAL ENERGY SERVICES, LLC REPORT 
Pace Global Energy Services investigated selected opportunities to further quantify the benefits and to estimate the costs to implement the reduction.

\section{Compressed Air System}

An array of rotary screw compressors supply the facilities with compressed air. Schematics of the compressed air systems are included in the respective sections. The following issues and opportunities for improvement were observed during our site visit and are arranged by production area.

- West Kill:

- Ensure the presence and proper operation of automatic zero loss drains

- Air Leak Maintenance

- Consider Looping

- Install 300 gallon Dry Receiver

- Compressor Maintenance (failed equipment and filters)

\section{West Kill - Compressed Air}

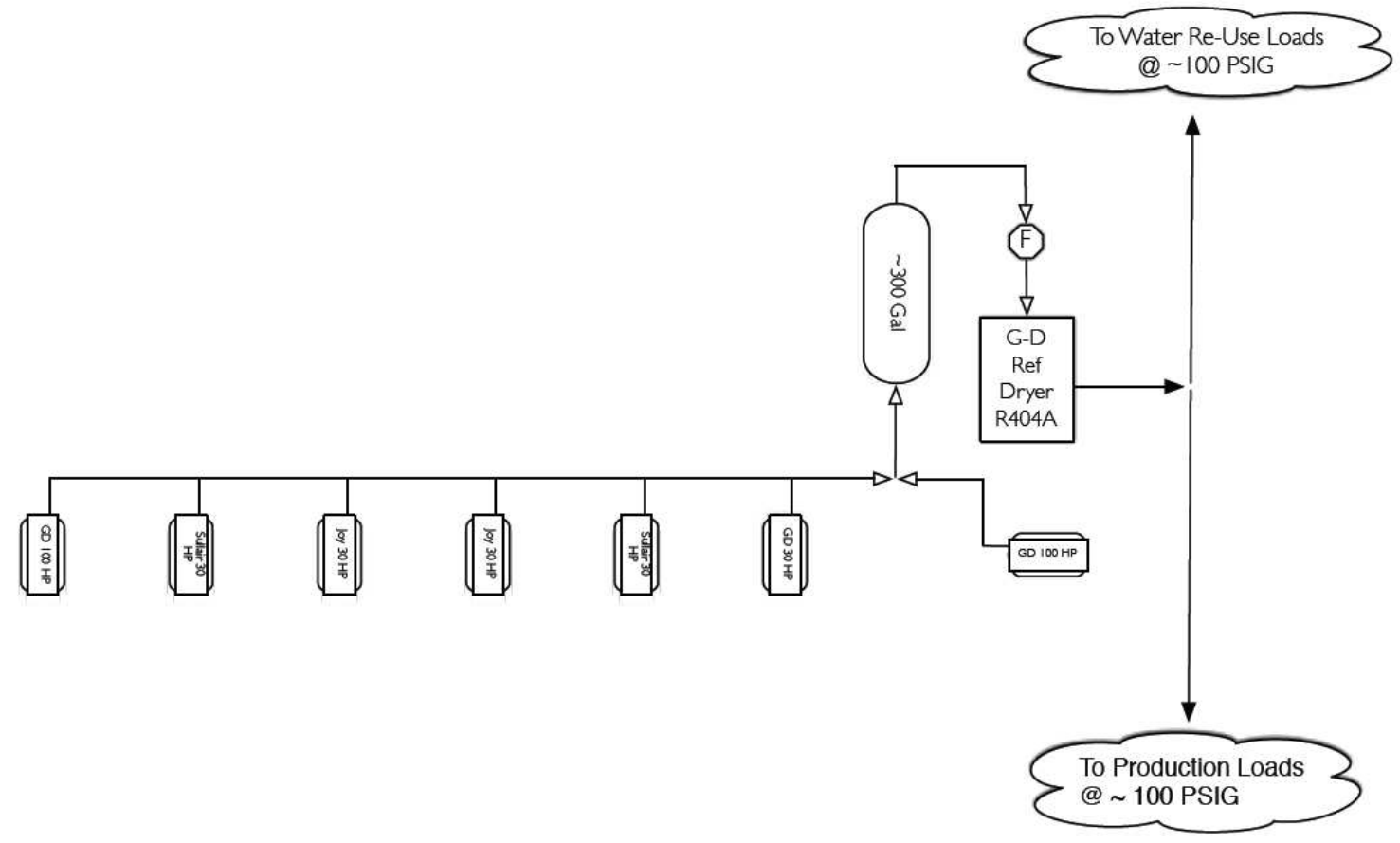

- $\quad$ East Kill

○ Operating well

- Excellent maintenance

- Ensure the presence and proper operation of automatic zero loss drains

- Ensure integrity of air distribution system 


\section{(e) PACE}

\section{East Kill - Compressed Air}

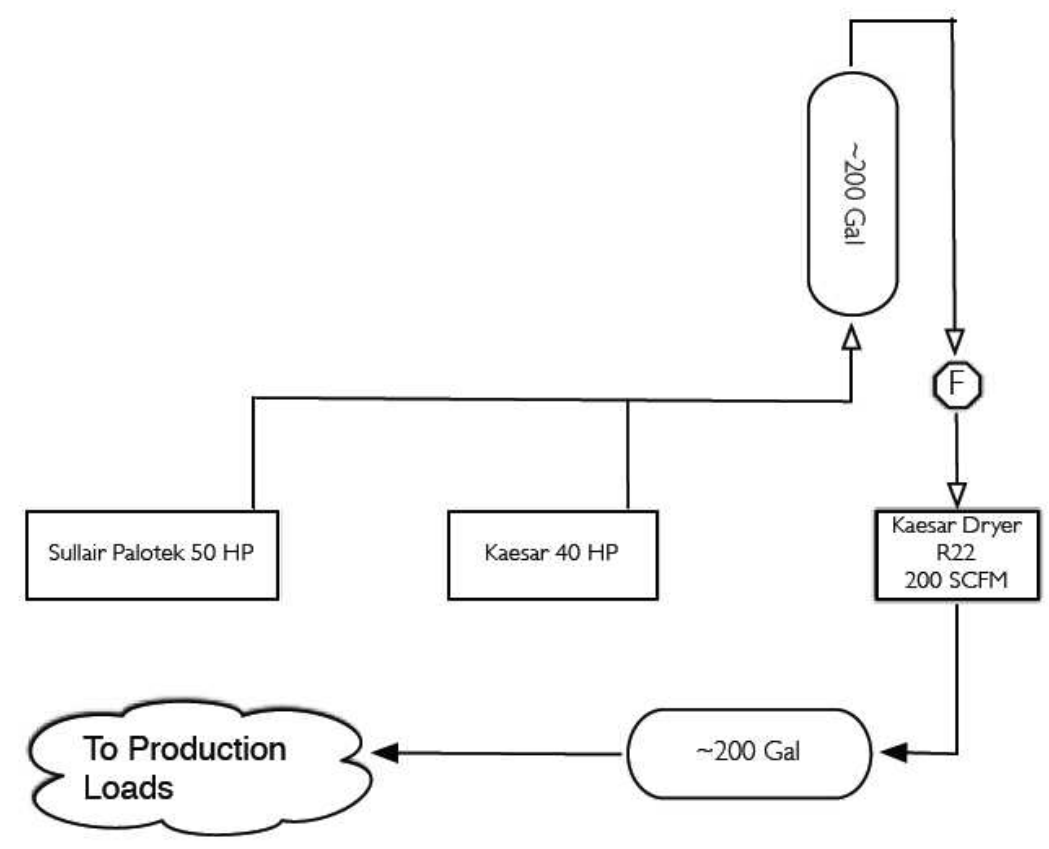

- Prepared Foods:

○ Inadequate compressor volume with respect to system condition

- Ensure the presence and proper operation of automatic zero loss drains

- Replace Desiccant Dryers with refrigerant dryers

- Air Leak Maintenance

- Consider Looping Air Lines

- PL-104 reliability suffers due to poor maintenance; system should be cleaned and maintained to ensure reliability and performance 


\section{Prepared Foods - Compressed Air}

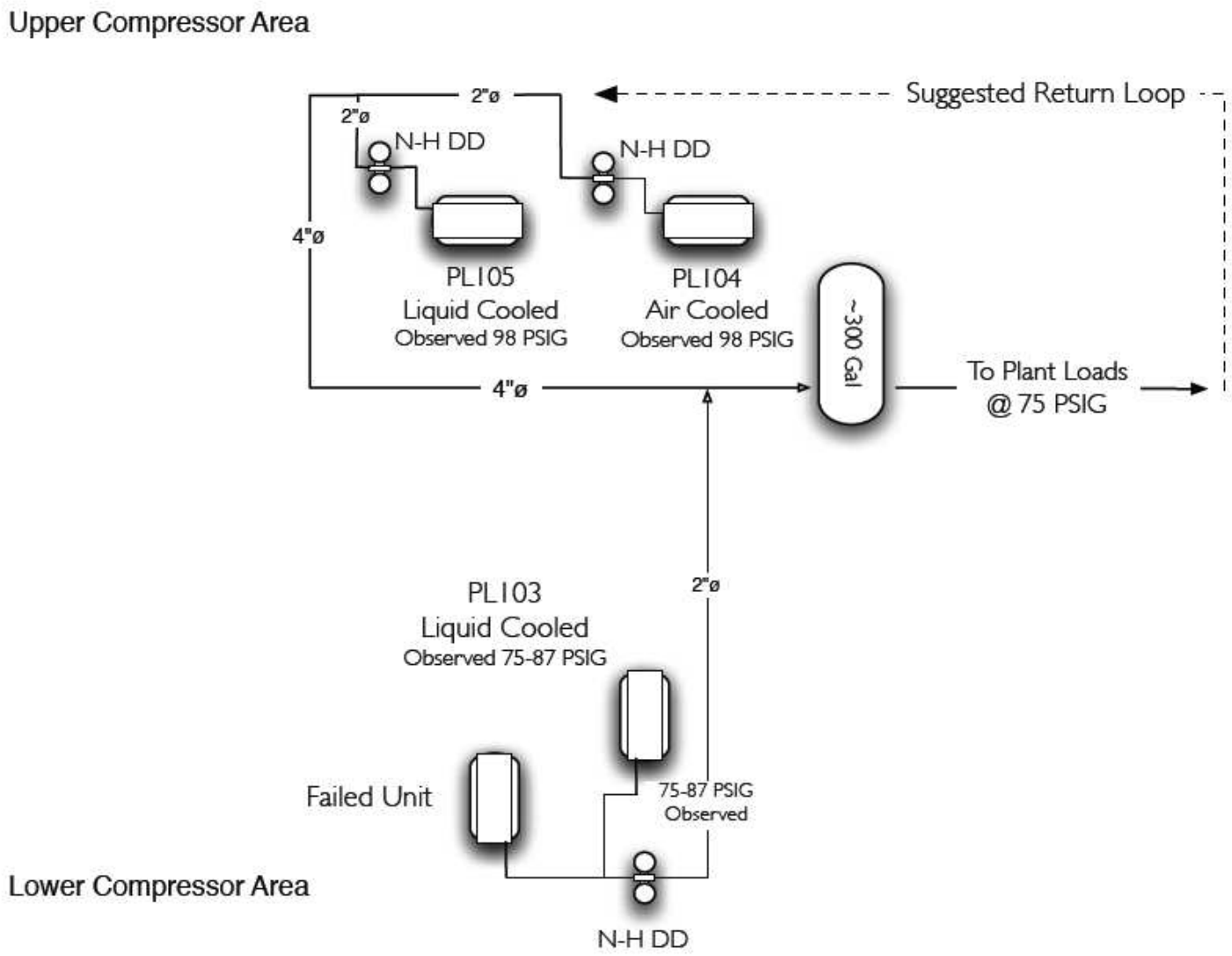

- Protein:

○ The 100hp Gardner Denver is oversized for given application (operation of fat filter diaphragm pump)

- Reliability of Atlas-Copco compressor, particularly during warm weather

- Ensure the presence and proper operation of automatic zero loss drains 
Protein - Compressed Air

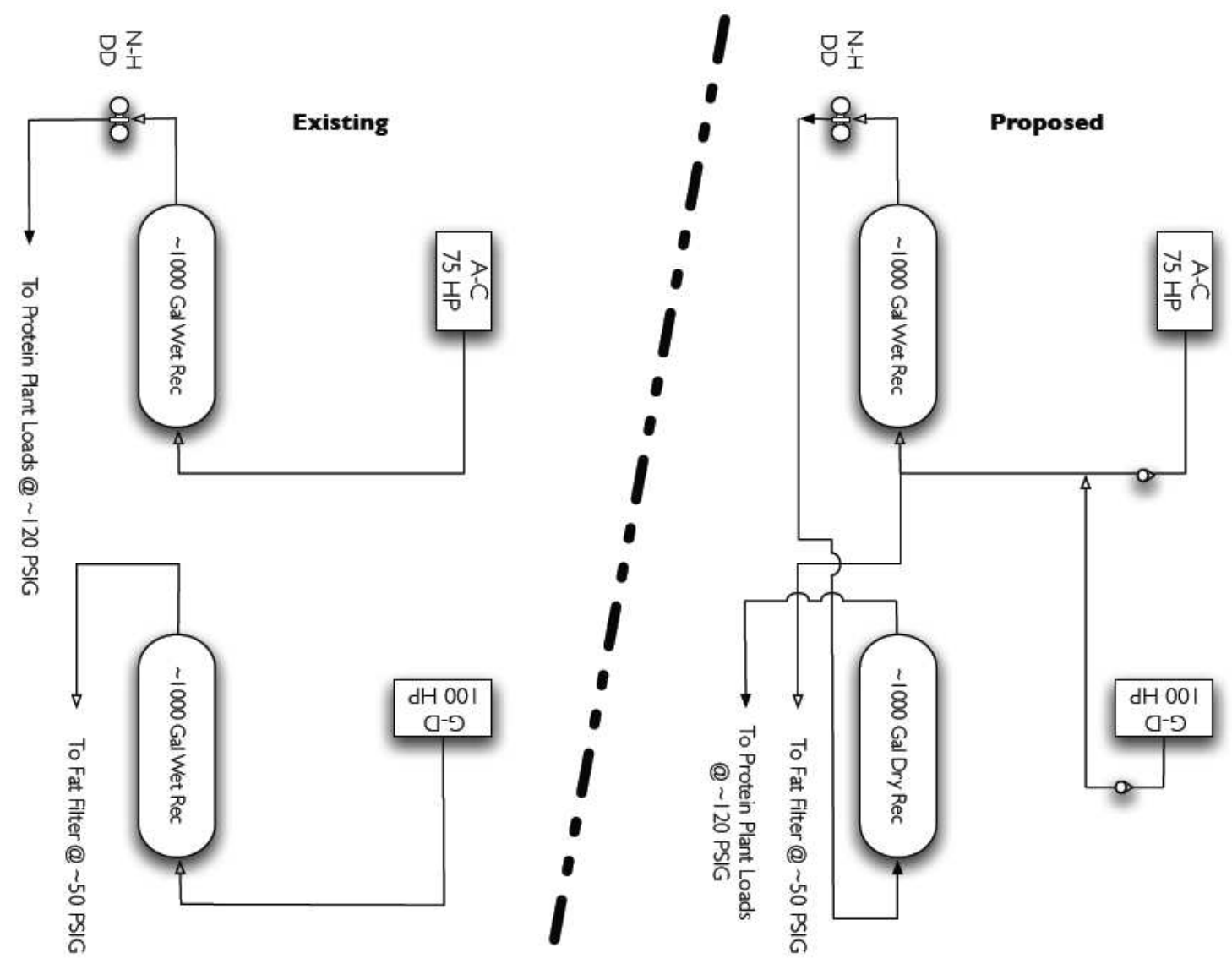

The following is a basic approach to improving the performance of compressed air systems:

1. Perform leak analysis (with an ultrasonic leak detector that can be utilized without interrupting production)

2. Install receivers where appropriate to maintain flow rates and reserve volumes

3. Loop distribution manifold where manifold design constrains flow

4. Consider condition and operation of condensate blowdown systems

5. Try to run the various processes with the system pressure decreased by 5 PSIG. If successful, consider 10 PSIG, or greater, to determine the minimum required delivery pressure for the various process areas.

6. Develop statement of condition (compressor equipment and distribution system) as it exists - repair as necessary

7. Observe production and confirm that compressed air is the best utility to use for all jobs it is presently being used for (e.g., a high volume, lower pressure blower may be a better choice)

8. After leaks are repaired, equipment condition ascertained, and otherwise unnecessary compressed air loads are eliminated, reappraise system operation/performance and consider capital improvements mentioned 
9. The predominance of the air compressors derive part load operation through slide valve control. In as much, variable frequency controls will not yield significant energy savings.

\section{Opportunities}

Fix the leaks and replace/repair the condensate drains. Purchasing ultrasonic leak detectors for maintenance personnel and implementing a routine for checking for leaks during production breaks will significantly reduce energy consumption and improve compressed air system performance. Additionally, many of the condensate drains on compressors and air receivers blow down constantly. Zero loss drains are inexpensive ways to blow out the water from the compressors without losing expensive compressed air. Repairing air leaks and installing zero loss drains will save approximately $376,000 \mathrm{kWh} / \mathrm{yr}$, or $\$ 18,000$. Ultrasonic leak detectors and zero loss drains will cost approximately $\$ 36,000$. Keeping up with air leaks will require an ongoing maintenance program.

Loop the manifolds and return the unused air to the dry receiver. This will improve system performance and in Prepared Foods potentially eliminate the need to replace the failed air compressor. Energy savings from this measure result from the opportunity to reduce system pressure.

Evaluate the system pressure. Repairing the air leaks and looping the manifold should improve the air system performance enough that the system pressure can be reduced. Air pressure should be tested at various locations in the system before lowering the compressor output pressure. These measures will result in energy savings of $76,000 \mathrm{kWh} / \mathrm{yr}$, or $\$ 3,600$. Looping the manifolds will cost approximately $\$ 31,000$; if the replacement of the compressor in Prepared Foods is no longer necessary this measure will pay for itself in less than two years.

In Prepared Foods, non-heated desiccant dryers are used to dry the air coming from the compressors. These dryers consume nearly $15 \%$ of the compressed air volume. Replacing the desiccant dryers with refrigerated dryers will save considerable energy, and money, as the dryers use electricity rather than expensive compressed air to dry the air. Of the three dryers in Prepared Foods, the one drying the air from PL104 should be replaced first. Replacing this dryer will save $\$ 2700$ per year and payback in 3 years. During our visit, compressor PL105 had the damper 1/3 closed; with this reduced flowrate replacing the dryer is not currently cost effective. Replacing the dryer serving PL-103 and the failed compressor could have added system benefits, but from an energy savings standpoint is not cost effective (the payback is greater than 10 years).

In Protein, compressor reliability and air storage are a concern. The Atlas-Copco unit is the primary compressor and overheats occasionally in warm temperatures. This compressor is connected to a wet receiver and a dryer. There is no dry receiver downstream of the dryer. The Gardner-Denver backup compressor is not fitted with a wet receiver or dryer. Connecting the two compressors in parallel will allow the backup compressor (ie the Gardner Denver) to more effectively support the primary compressor; additionally, one receiver can be converted to a dry receiver to improve system efficiency. A small pressure reducing regulator fitted to the wet 
receiver would continue to supply air to the fat filter diaphragm pump at the required $50 \mathrm{psig}$. A schematic of the proposed setup is included above. The energy savings are minimal for this recommendation, $12,000 \mathrm{kWh} / \mathrm{yr}$ or $\$ 800$, but there will be additional savings in avoided maintenance cost and extended equipment life. Implementation of this recommendation is estimated at $\$ 2,500$. After implementing the recommendations, evaluate the potential for reducing the pressure output from the compressors while still satisfying process demands. Another benefit of supplementing the output of the Atlas-Copco with the Gardner Denver compressor is the ability to satisfy the compressed air needs of pretreatment ( $30 \mathrm{hp})$ precluding the need for a dedicated compressor for pretreatment.

\section{Variable Frequency Drives}

Large motors and pumps (over 30hp) at the Mt Pleasant facility represent $17 \%$ of the electric load. As many of these motors operate over broad ranges and/or operate for extended periods of time at part load they are excellent candidates for variable frequency drive (VFD) control. VFDs facilitate adjusting the speed of the motor based on the load; a $2 \%$ reduction in the speed of the motor results in a $4 \%$ reduction in power consumption. For this reason, VFD controls on motors driving varying loads can save a significant amount of energy. Pilgrim's personnel provided approximate load factors for motors and helped identify motors suitable for VFDs. The total savings from the VFD applications listed in Exhibit 8 below is $4,268,000 \mathrm{kWh} / \mathrm{yr}$, or $\$ 204,000 / y r$. Purchasing and installing the VFDs is estimated to cost $\$ 375,000$. The project should pay back in 2 years.

Exhibit 8: Variable Frequency Drive Applications

$\begin{array}{llll}\text { Location } & \text { Description } & \text { Horsepower } & \text { Load Variation } \\ \text { East Kill } & \text { Vacuum Pump } & 1 \times 75 & 70 \% \text { speed/70\% hours } \\ \text { East Kill } & \text { Washdown Pump } & 1 \times 60 & 50 \% \text { speed/100\% hours } \\ \text { West Kill } & \text { Vacuum Pump } & 1 \times 100 & 70 \% \text { speed/70\% hours } \\ \text { West Kill } & \text { Washdown Pump } & 1 \times 100 & 70 \% \text { speed/100\% hours } \\ \text { Protein Conversion } & \text { Hot Water Pump } & 1 \times 100 & 80 \% \text { speed/100\% hours } \\ \text { Wastewater Treatment } & \text { Aerators } & 17 \times 75 & 60 \% \text { speed/50\% hours } \\ \text { Wastewater Treatment } & & 2 \times 175 & 80 \% \text { speed/100\% hours }\end{array}$

\section{Wastewater Treatment Water Flow}

The waste water treatment plant (WWT) receives post-process water from the facilities. This effluent is collected in the basement of the Protein Plant. From there, pumps convey the water to a nearby pretreatment facility. Primary equipment in pretreatment includes 6 roller screens, 2 belt presses, 5 dissolved air flotation units, and 5 pumps $(4 \times 30 \mathrm{hp}$ constant speed and $1 \times 50 \mathrm{hp}$ on an on/off float control). Pre-treated effluent is then pumped (for final treatment) some 2 miles to a POTW operated by Pilgrim's Pride staff. Roughly $85 \%$ of the materials processed by the 
POTW are associated with Pilgrim's and the remainder consists of sanitary sewage from the surrounding community.

POTW system operational dynamics dictate that flows derived from the Pretreatment facility be maintained at 3.5 MGD. Flows exceeding this value are temporarily diverted (using manual controls) to a surface impoundment pond adjacent to the Pretreatment facility. The pond has a capacity of $\sim 1$ million gallons of water. This water is then returned (gravity feed) to the Protein basement and may be circulated repeatedly through Pretreatment prior to ultimately being delivered to WWT. In this manner the pond serves as a buffering element to "smooth" flows to WWT. Negative effects of this routine include excessive power consumption associated with the circular pumping process, the requirement for pond odor control and the power consumption associated with the operation of aeration equipment intended to minimize those odors, and a labor intensive, sub-optimal methodology of process control.

\section{Exhibit 9: Current Waste Water Configuration}

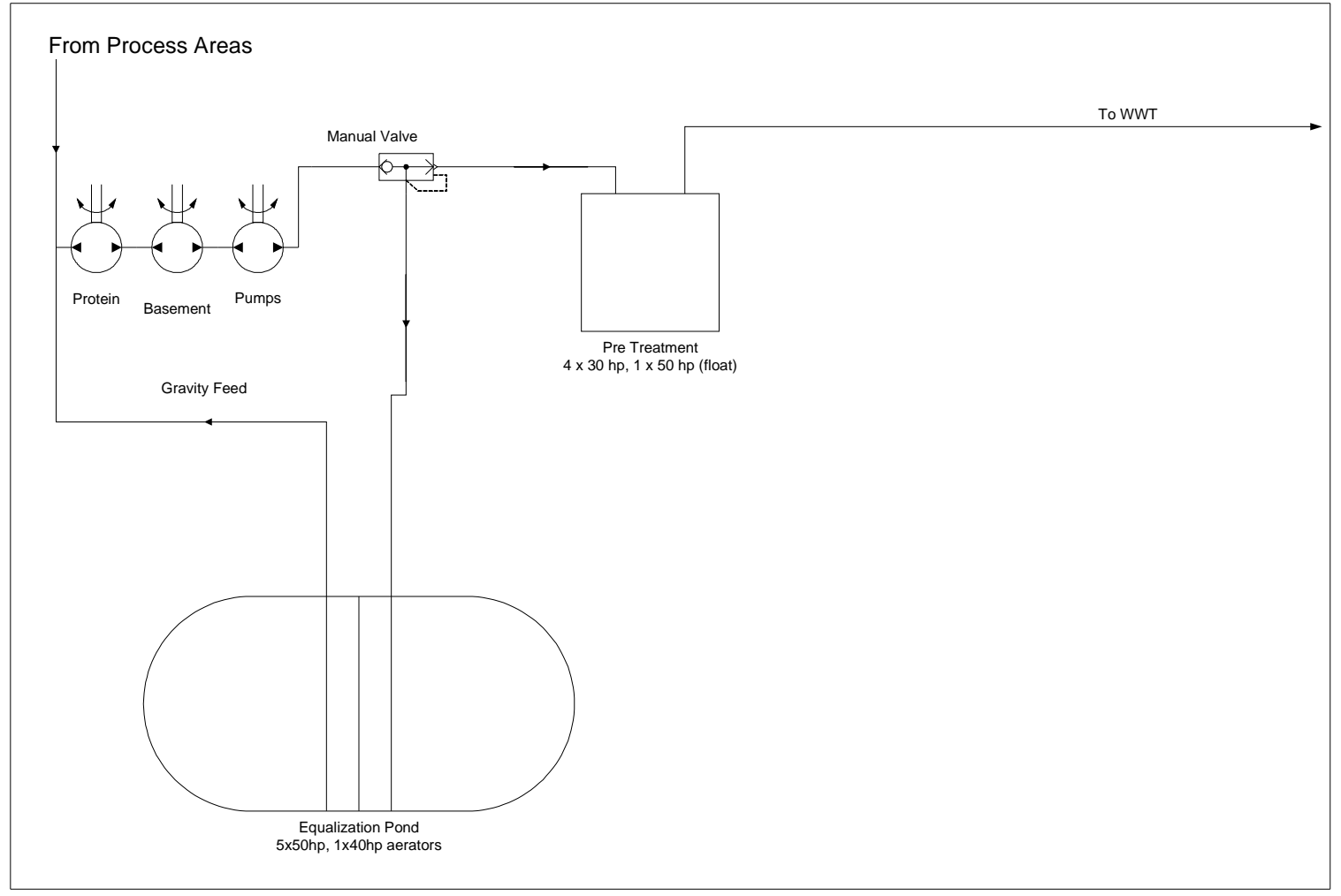

\section{Description of the Problem}

Exhibit 10 represents water flow meter readings taken at WWT between September 10 and September 16, 2006. Flow to WWT peaks mid morning each week day following the wash down cycles in the production plants. When the flow rate exceeds the capacity that the WWT 
facility can handle, an alarm sounds and the water is redirected to the equalization pond. Currently, the only way to reintroduce water from the equalization pond to the WWT conduit is to return it to the basement of Protein (in effect "re-contamination" and "re-processing").

Exhibit 10: Sample of Wastewater Flow to WWT

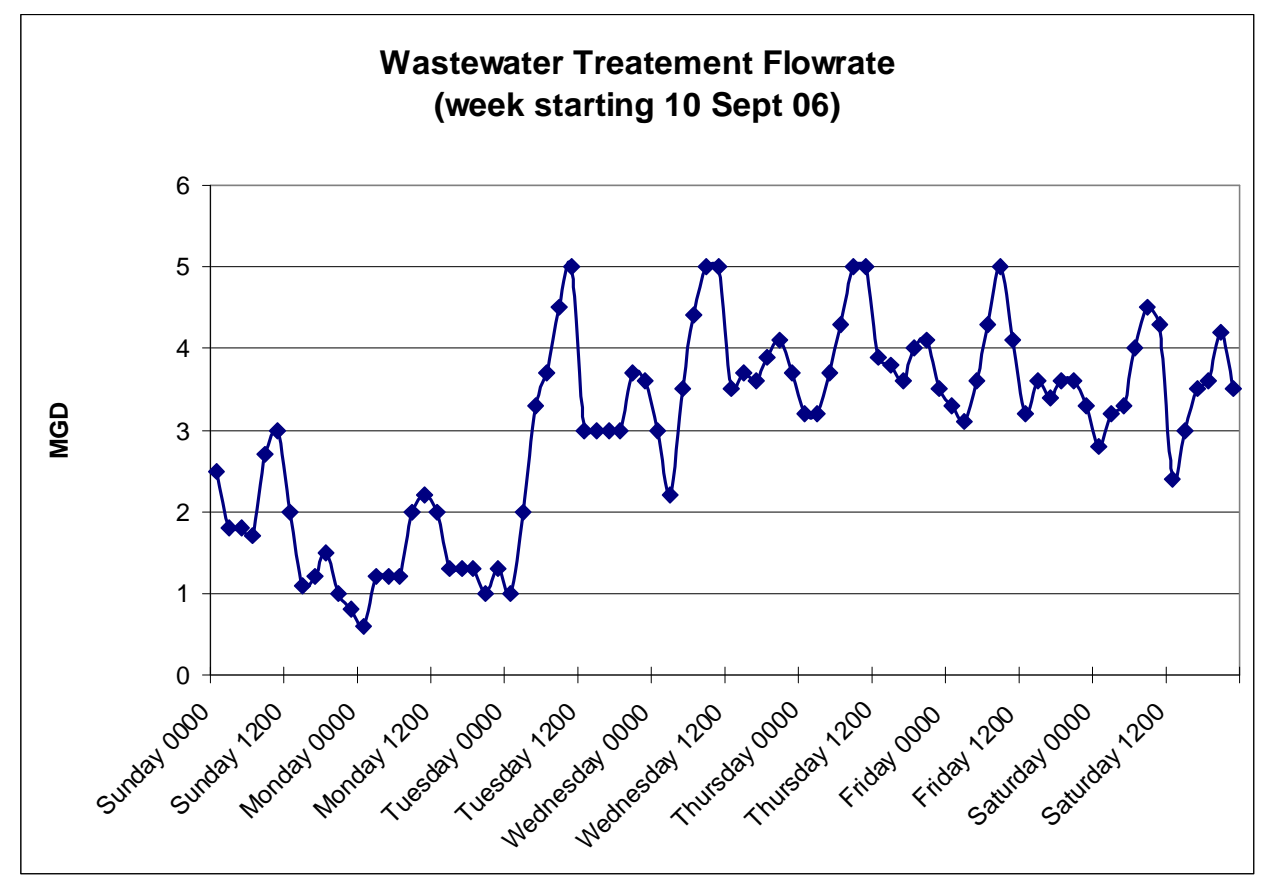

\section{Recommendation}

This process is an excellent candidate for automation, leading to reduced energy consumption, wear and tear on system components, treatment chemicals, and tighter process control. Automation will result in energy savings from reduced pumping (recirculated flow through the Protein Basement) and Aeration loads (in the Impoundment Pond). Operational savings will result from improved process control and potential chemical agent reduction in WWT. Exhibit 11 below is a representation of the automated configuration of the waste water flow system. 
Exhibit 11: Recommended Waste Water System Configuration

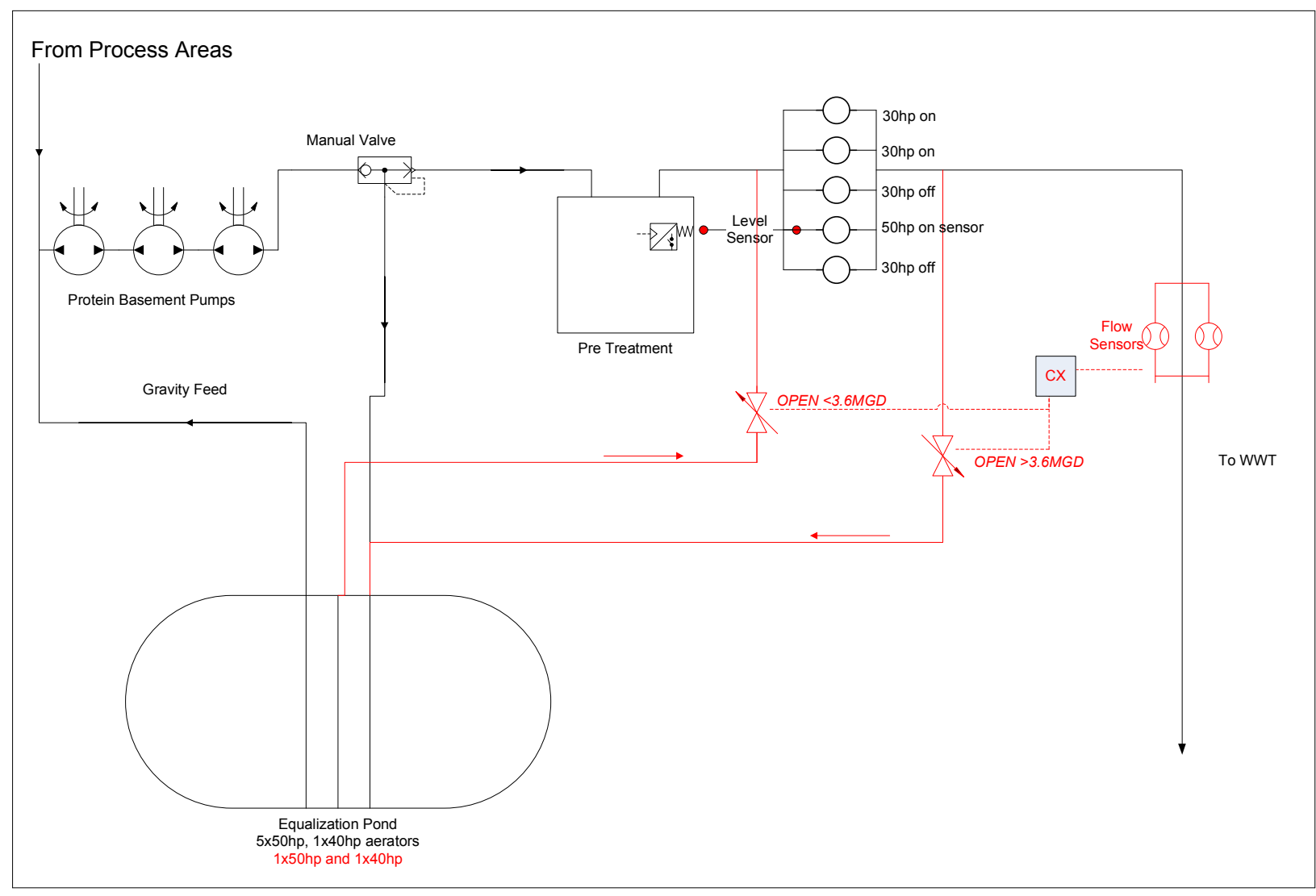

While WWT can accept a maximum flow of 5.8 MGD, its operators would prefer to maintain this flow at or near 3.5 MGD (e.g. the "target flow rate"). A paddle-wheel flow sensor system (redundant sensors) installed between pretreatment and WWT will monitor actual, instantaneous, flow rates and provide a control signal to an industrial process controller installed and configured to maintain the flow of effluent previously diverted to the impoundment pond directly into the WWT supply line at an aggregate rate not to exceed the desired 3.5 MGD.

At times when measured flows to the WWT facility exceed 3.6 MGD the process controller will modulate a motorized Valve B incrementally to release excess flow to the impoundment pond. Alternately, measured flow rates of less than 3.6 MGD will cause the process controller to open Valve A (Valve B closed) to the specific degree that facilitates the induction of impoundment pond water (so long as the pond is $50 \%$ full as measured by a float type mechanism) to arrive at the target 3.6 MGD flow rate.

\section{Energy Savings}

The energy savings for this recommendation come from a reduction in the operating aerators in the equalization pond. Aeration can be reduced from 5x50hp and 1x40hp to 1x50hp and 1 $40 \mathrm{hp}$. 
Also, one pump in the basement of Protein will no longer be necessary (although it should be maintained as a backup). The annual energy savings are estimated to be $1,330,000 \mathrm{kWh} / \mathrm{yr}$ with a potential demand reduction of $200 \mathrm{~kW}$. With electric rates of $\$ 0.0479 / \mathrm{kWh}$ and $\$ 5.01 / \mathrm{kW} \cdot \mathrm{mo}$, the annual savings is estimated to be $\$ 72,500$.

\section{Implementation Cost}

The cost of the recommendation is approximately $\$ 100,000$ and includes the following equipment:

Process controller, flow sensors, and valves $(\$ 50,000)$

PVC piping $(\$ 35,000)$

Miscellaneous costs including fittings and labor

\section{Lighting}

The non-production areas of the Mt. Pleasant facility provide several opportunities for improved lighting efficiency. These areas are the Truck Shop, the Spice Room and the Box Room, both in Prepared Foods.

Hibay lighting in the Truck Shop is $400 \mathrm{~W}$ probe start Metal Halide lamps. Replacing these lamps with T8 hibay fixtures, 6 lamps per fixture, will reduce energy consumption by 130,000 $\mathrm{kWh} / \mathrm{yr}$. This retrofit is very common and is a one for one replacement (some testing of these fixtures has been done in the Spice Room of Prepared Foods as described below). The cost of the retrofit is estimated at $\$ 31,500$, including labor. This project should pay back in approximately 5 years.

Office lighting in the Truck Shop is 2x4 fixtures with 4 T12 lamps per fixture. Replacing the lamps and ballasts with more energy efficient T8 lamps can reduce energy consumption by 62 watts per fixture. The new fixtures should contain $2 \mathrm{~T} 8$ lamps with a high efficiency high ballast factor ballast. An exact count of these fixtures was not obtained, but the energy savings, and implementation cost, will be the same for each fixture. This project should pay back in two years or less.

The Box Room in Prepared Foods is lit by 8ft T12 strips with 2 lamps per fixture. These lamps can easily be replaced with two 4ft T8 lamps with a high efficiency standard ballast factor ballast. This will reduce the energy consumption per fixture by 110 watts. The total energy savings in the Box Room is estimated to be $71,300 \mathrm{kWh} / \mathrm{yr}$ or $\$ 3,415$. The implementation cost should be approximately $\$ 5,200$, with a simple payback of 1.5 years.

The Spice Room in Prepared Foods has a mixture of high bay lighting. The lighting is primarily Metal Halides, but there are some strip T12 lamps and three T8 hibay fixtures. The T8 hibays should be installed throughout the room. See Exhibit 12 below for a comparison of the hibay lighting options. 
On the production floor, light fixtures need to be able to withstand the high pressure washdown cycles. For this reason, few options are currently available to plant personnel to reduce energy usage. During the site visit, Pace Global was informed that Pilgrims is working with light fixture manufacturers to develop fixtures for T5HO high efficiency lights that will withstand the washdown environment. The T5HO lamps are approximately 54W each; model numbers for the current T12 lamps could not be obtained but based on prior experience they are at least $75 \mathrm{~W}$ each. Additionally, the lamp life on T5HOs is at least twice that of the T12s. Replacing the T12 lamps and fixtures with T5HO lamps is fixtures should yield attractive energy savings.

Exhibit 12: Comparison of Lighting Systems

\begin{tabular}{|l|c|c|}
\hline & Fixture Wattage & Lamp Life (hours) \\
\hline HiBay Lighting & & \\
\hline 400W Metal Halide (probe start) & 426 & 10,000 \\
\hline 250W Metal Halide (pulse start) & 288 & 15,000 \\
\hline T8 flourescents (6 lamps) & 220 & 24,000 \\
\hline
\end{tabular}

\section{Synchronous Belt Replacement}

Replace conventional drive belts on motors with banded cogged belts. Energy savings of 3\% are typical as are substantial increases in the service life of the belts. Energy savings come from reduced slippage. Assuming half of the motors over $30 \mathrm{hp}$ are suitable for belt replacements, the energy savings potential is $468,000 \mathrm{kWh} / \mathrm{yr}$ or $\$ 22,500$. The belts, sheaves, and labor to replace them are estimated at $\$ 16,500$. 
HUDSON TECHNOLOGIES COMPANY FINAL REPORT 


\title{
HUDSロN
}

TEエHNロLロGIES

\section{Steam \& Waste Heat Recovery Systems Energy Savings Assessment - Mt. Pleasant, TX Facility}

\author{
Prepared for: \\ Keith Wittebort \\ Pilgrim's Pride Corporation \\ 4845 Highway 271 North \\ Pittsburg, TX 75686. \\ Email: kwittebort@pilgrimspride.com \\ Prepared by: \\ Riyaz Papar, PE, CEM \\ Hudson Technologies Company \\ 14 Split Rail Place \\ The Woodlands, TX 77382. \\ Phone: (281) 2980975 \\ Email: rpapar@hudsontech.com
}

FEBRUARY 12, 2007

Pilgrim's Pride Reference \# DE-FC36-05G015099

Hudson Technologies Reference \# 07-001-1

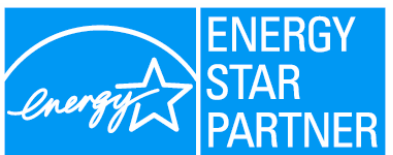




\section{ACKNOWLEDGEMENTS}

Hudson Technologies (Hudson) would like to thank personnel from the Pilgrim's Pride Corporation and PACE Global Energy Services for giving us the opportunity to undertake the steam and waste heat recovery system assessment at the Mt. Pleasant, TX facility.

Plant personnel have previously undertaken efforts to optimize the boiler plant and have developed good information about how to monitor and operate the system reliably. This information has been very helpful in determining additional strategies and protocols that are critical for optimization and load management strategies. There were also several ideas for better operation and control that originated during our discussions with Pilgrim's Pride personnel.

\section{DISCLAIMER}

The information provided in this report is based on the data provided by Pilgrim's Pride Corporation. Hudson or any of its employees do not take any responsibility for any liabilities or misinformation that may be reported here. 


\section{TABLE OF CONTENTS}

INTRODUCTION \& OVERVIEW

Project Objectives

Project Tasks

Steam System Overview

Steam System BestPractices

Steam \& Process Heat System Overview

Proteins Conversion

Prepared Foods

West Kill Plant

East Kill Plant

12

Truck Shop

Energy Conservation Measures

Proteins Conversion Plant ECMs

Prepared Foods Plant ECMs

Kill Plants \& Truck Shop ECMs

26

Mt. Pleasant, TX Site-Level ECMs

26

Summary of ECMs

\section{APPENDIX}

A1: Hot Water Usage Calculations 31

A2: Proteins Conversion Boilers Combustion Efficiency 32

A3: Natural Gas Combustion Efficiency Model 34

A4: Thermosorber "Watt Poultry USA" Article 35 


\section{INTRODUCTION}

This section provides a basic introduction to the project by detailing the project scope and objectives of the Steam and Waste Heat Recovery assessment at the Mt. Pleasant, TX facility of Pilgrim's Pride Corporation.

\section{Project Objectives}

During the month of November 2006, Riyaz Papar, PE, CEM (Hudson Technologies Company) visited the Mt. Pleasant, TX facility. This visit was facilitated by PACE Global Energy Services and consisted of a team of subject matter experts. This project was part of the US DOE PlantWide Assessment (PWA) that was awarded to Pilgrim's Pride Corporation. This project involved a 5-day in-plant study of the current operating practices of the steam and waste heat recovery systems and identified energy savings opportunities.

The project had two main focus areas:

- Steam Generation and Condensate Return

This portion reviewed the current steam and condensate system and developed a strategy for best meeting the current and future steam needs at the lowest overall cost.

- Process Heat Recovery Opportunities

This portion analyzed the opportunity for recovering waste heat and investigated opportunities for using this heat effectively at the facility. 
Nevertheless, overall facility optimization, boiler operation and load management and other potential energy and cost savings measures were also investigated during the course of this PWA. The other objectives of this project included completing a detailed energy supply and demand analysis on the natural gas side to quantify usages at the different energy cost centers (end-users).

\section{Project Tasks}

The different tasks that were performed during the course of this project are outlined below:

\section{Task 1: Use of DOE Steam System Scoping Tool (SSST)}

Before undertaking any detailed steam energy savings assessment, use of the DOE BestPractices SSST provides significant insight and identifies areas that would need focused attention. The SSST consists of qualitative questions and also serves as an excellent way to understand steam system operating and maintenance practices. The SSST provides a score that can help plant personnel understand their shortcomings and allows them a way to compare their operations with others in the industry.

\section{Task 2: Identification of steam end users (cost centers)}

This task identified the energy flow (supply and demand) of steam and natural gas at the different cost centers at the Mt. Pleasant, TX facility. It has to be noted that sub-metering is not available at all the individual equipments / processes but an attempt was made to ensure that all the loads were identified and quantified in the next task. 


\section{Task 3: Data analysis \& load profiling}

A detailed data analysis spanning almost 5 months (07/01/06 - 11/28/06) was used to further understand the performance and operation of the Proteins Conversion boiler plant. The data was provided by the Data Acquisition System (DAS) historian at the Proteins Conversion plant in the form of parameter plots. From this analysis, an average load profile was developed and used in the optimization and development of the load management strategy. More importantly, this task provided extremely valuable information to development of individual boiler performance and equipment characteristics (baselining / benchmarking).

\section{Task 4: Identification of steam Energy Conservation Measures (ECM)}

Most of the effort of the project was spent on this task. Several tools including the US DOE's Steam System Assessment Tool (SSAT), 3EPlus insulation evaluation software and other proprietary models were used to quantify the potential steam energy savings opportunities.

\section{Task 5: Identification of waste heat recovery ECMs}

This part of the effort mainly focused on waste heat recovery from flue gas streams and any other sources. It did have some overlap with Task 4 but most of the concentration of this effort of the project was on oil heaters in the Prepared Foods plant. 


\section{Task 6: Identification of overall facility level ECMs}

This task took an overall systems approach of the facility and tried to identify any overall facility level energy saving opportunities that may exist to improve the overall plant level energy efficiency.

\section{Task 7: Prepare final report}

A detailed final report was prepared in this task to report on all the opportunities, model results and additional resources. 


\section{STEAM SYSTEM OVERVIEW}

The Mt. Pleasant, TX facility has six main areas that are identified as the main cost centers. They are:

- Proteins Conversion

- Prepared Foods

- West Kill plant

- East Kill plant

- Truck Shop

- Waste Water Treatment plant

It has to be noted that although these areas are identified as discrete cost centers, there is overlap (energy transfer) from the Proteins Conversion area to the other areas, mainly in the form of transfer of hot water. Appendix A1 provides an estimate for this hot water transfer.

\section{Steam System BestPractices}

The Proteins Conversion boiler plant has four (\#1, \#2, \#3 and \#4) natural gas fire-tube boilers. This boiler plant accounts for more than $80 \%$ of the Mt. Pleasant, TX facility natural gas usage and all of it is used to produce steam. The US DOE Steam System Scoping Tool (SSST) was used to first evaluate the overall steam system practices and compare it to state-of-the-art industry bestpractices. For additional information on DOE steam software tools, go to http://www1.eere.energy.gov/industry/bestpractices/software.

SSST is designed to help steam system energy managers and operations personnel to perform initial self-assessments of their steam systems. The tool profiles and grades steam system operations and management. The tool evaluates steam system operations against best practices. 
The SSST has four sections and asks qualitative questions in each of the areas. The tool compares the answers provided to these questions with bestpractices and assigns a numerical score based on a pre-defined algorithm. Table 1 provides the results of the SSST for the Mt. Pleasant, TX facility and also compares it to an industry average as observed in other industrial plants. Note that the intention of the tool is not to benchmark the facility or provide any quantitative information on savings opportunities. The sole purpose is to provide a basic understanding of the steam system management and identify areas that may result in the highest savings opportunities. In summary, it provides a simplistic gap analysis for any steam system.

At first glance, the Mt. Pleasant, TX facility shows a below average operation compared to a typical average industry scores. The Mt. Pleasant, TX facility scored a total of $158(46.5 \%)$ versus the industry average of $223(65.5 \%)$. But a closer comparison reveals that the difference between the facility and industry is manifested in the first three categories that are focused on steam system profiling, operating practices and the boiler plant. Nevertheless, it is important to realize that this is a starting point for due diligence activities.

Table 1: $\quad$ Results of US DOE SSST on the Mt. Pleasant, TX Facility 


\begin{tabular}{|c|c|c|c|}
\hline Category Description & $\begin{array}{l}\text { Maximum } \\
\text { Score }\end{array}$ & $\begin{array}{l}\text { Mt. Pleasant, } \\
\text { TX Score }\end{array}$ & $\begin{array}{l}\text { Industry } \\
\text { Average* }\end{array}$ \\
\hline Steam system profiling & 90 & 32 & 53 \\
\hline Steam system operating practices & 140 & 75 & 104 \\
\hline Boiler plant operating practices & 80 & 35 & 50 \\
\hline $\begin{array}{l}\text { Distribution, end-use, recovery } \\
\text { operating practices }\end{array}$ & 30 & 16 & 16 \\
\hline Total & 340 & 158 & 223 \\
\hline Total (\%) & 100 & 46.5 & 65.5 \\
\hline
\end{tabular}

*Data obtained from the US DOE Steam BestPractices End-user Training

The results of SSST are not meant to quantitatively imply any potential energy savings. From a corporate standpoint, the SSST can be used on different Pilgrims Pride facilities and the results from all the facilities can be compared by the Corporate Energy Manager to prioritize assessments or audits at the different facilities. The lower the SSST score, the higher the probability of finding energy efficiency projects and implementing bestpractices.

\section{Steam \& Process Heat System Overview}

The total annual natural gas usage for the Mt. Pleasant, TX facility is $\sim 1,733,100$ MMBtu. A small amount of waste motor oil $(\sim 1,700 \mathrm{MMBtu})$ is also burned in the Truck shop to provide space heating. Average natural gas cost used in this analysis is $\$ 9.374 / \mathrm{MMBtu}$, electric utility cost is $\$ 0.04790 / \mathrm{kWh}$, water cost (including chemicals) is $\$ 2.10 / \mathrm{Mgal}$ and sewage cost is $\$ 4.38 / \mathrm{Mgal}$. This section details the overall steam and process heating system that exists at the Mt. Pleasant, TX facility.

Figure 1 presents the annual energy usage breakdown for the major natural gas users by plant at the Mt. Pleasant, TX facility. Proteins Conversion uses almost $66.7 \%$ of the total natural gas. Prepared Foods uses $30.2 \%$ of the total site's natural gas. The "Other" category that consists of 
the East and West Kill plants and the Truck Shop constitutes only 3.1\% of the total site's natural gas usage. Table 2 presents the actual detailed tabulated information for all the plants and summarizes the total natural gas and waste motor oil usage at the Mt. Pleasant, TX site.

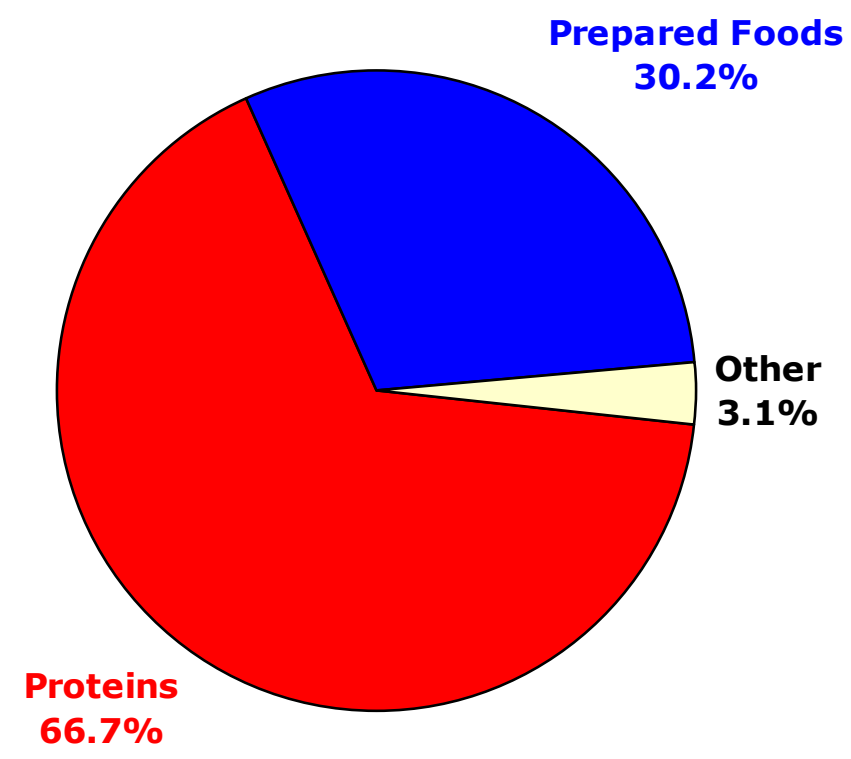

Figure 1: Annual natural gas consumption at Mt. Pleasant, TX site (Total: 1,734,800 MMBtu; \$16,246,000)

Table 2: Annual Fuel Usage Breakdown at Mt. Pleasant, TX site 


\begin{tabular}{|l|r|r|r|r|r|}
\hline \multirow{2}{*}{ Plant } & \multicolumn{1}{c|}{ Natural Gas } & Waste Oil & \multicolumn{2}{c|}{ Total } & \multicolumn{1}{c|}{ \% of Total } \\
\cline { 2 - 6 } & (MMBtu) & (MMBtu) & \multicolumn{1}{c|}{ (MMBtu) } & \multicolumn{1}{c|}{$\mathbf{( \% )}$} \\
\hline Proteins Conversion & $1,157,336$ & - & $1,157,336$ & $10,848,867$ & 66.7 \\
\hline Prepared Foods & 523,598 & - & 523,598 & $4,908,204$ & 30.2 \\
\hline West Kill Plant & 26,730 & - & 26,730 & 250,567 & 1.5 \\
\hline East Kill Plant & 18,813 & - & 18,813 & 176,352 & 1.1 \\
\hline Truck Shop & 6,624 & 1,711 & 8,335 & 62,093 & 0.5 \\
\hline Total & $\mathbf{1 , 7 3 3 , 1 0 0}$ & $\mathbf{1 , 7 1 1}$ & $\mathbf{1 , 7 3 4 , 8 1 1}$ & $\mathbf{1 6 , 2 4 6 , 0 8 3}$ & $\mathbf{1 0 0 . 0}$ \\
\hline
\end{tabular}

This section now provides information on the individual cost centers both for steam and process heat production and usage. Currently, steam is not distributed across the different plants and the individual plants have their own boilers for producing steam. On the other hand, hot water is supplied from the Proteins Conversion to both the Kill plants and Prepared Foods.

\section{Proteins Conversion}

Steam is produced in a central boiler plant in the Proteins Conversion area and distributed within the plant to the different users. The central boiler plant operates $\sim 6,480$ hours $(5,24 \mathrm{hr}$ days +10 Saturdays) annually. There are four natural gas fired fire-tube boilers that provide saturated steam at $~ 120$ psig to the plant. The nameplate information on the boilers is as follows:

\section{$\underline{\text { Boiler \#1 }}$}

Model Number: PFTE 2000-3G150S

Manufacturer: Johnston Boiler Company

Capacity: $2000 \mathrm{hp}(\sim 65,000 \mathrm{lb} / \mathrm{hr}$ steam $)$

Pressure Rating: 150 psig 
Number of passes: 3

Blower: 100 hp (124A, 460V)

Maximum gas flow rate: $83,700 \mathrm{scfh}$

$\underline{\text { Boiler \#2 }}$

Model Number: PFTA 1500-4G150S

Manufacturer: Johnston Boiler Company

Capacity: 1500 hp ( 50,000 lb/hr steam)

Pressure Rating: 150 psig

Number of passes: 4

Blower: $150 \mathrm{hp}(180 \mathrm{~A}, 460 \mathrm{~V})$

Maximum gas flow rate: $62,853 \mathrm{scfh}$

\section{$\underline{\text { Boiler \#3 }}$}

Model Number: PFTA 1200-4G150S

Manufacturer: Johnston Boiler Company

Capacity: 1200 hp ( 40,000 lb/hr steam)

Pressure Rating: 150 psig

Number of passes: 4 
Blower: 100 hp (124A, 460V)

Maximum gas flow rate: $51,850 \mathrm{scfh}$

\section{Boiler \#4}

Model Number: PFTA 1200-4G150S

Manufacturer: Johnston Boiler Company

Capacity: $1200 \mathrm{hp}(\sim 40,000 \mathrm{lb} / \mathrm{hr}$ steam $)$

Pressure Rating: 150 psig

Number of passes: 4

Blower: 75 hp (92A, 460V)

Maximum gas flow rate: 48,500 scfh

Boiler efficiency curves were developed based on burner tune up and flue gas stack analyses records obtained from plant personnel. These are provided in the Appendix - A2. Figure 2a shows the annual breakdown of natural gas consumption in the boiler plant. Figure $2 \mathrm{~b}$ shows the average boiler load duty (actual firing rate divided by maximum firing rate) in the boiler plant. 


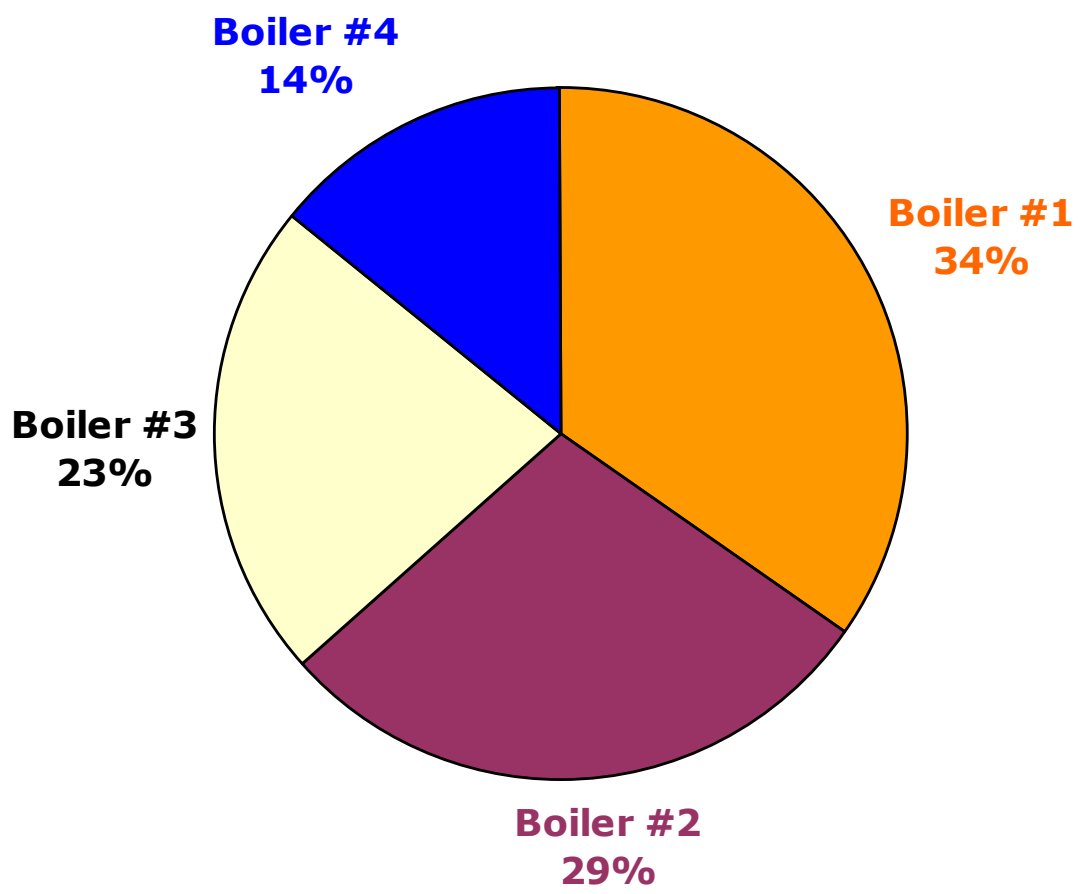

Figure 2a: Annual natural gas consumption

Figure 2B: Average Boiler Load

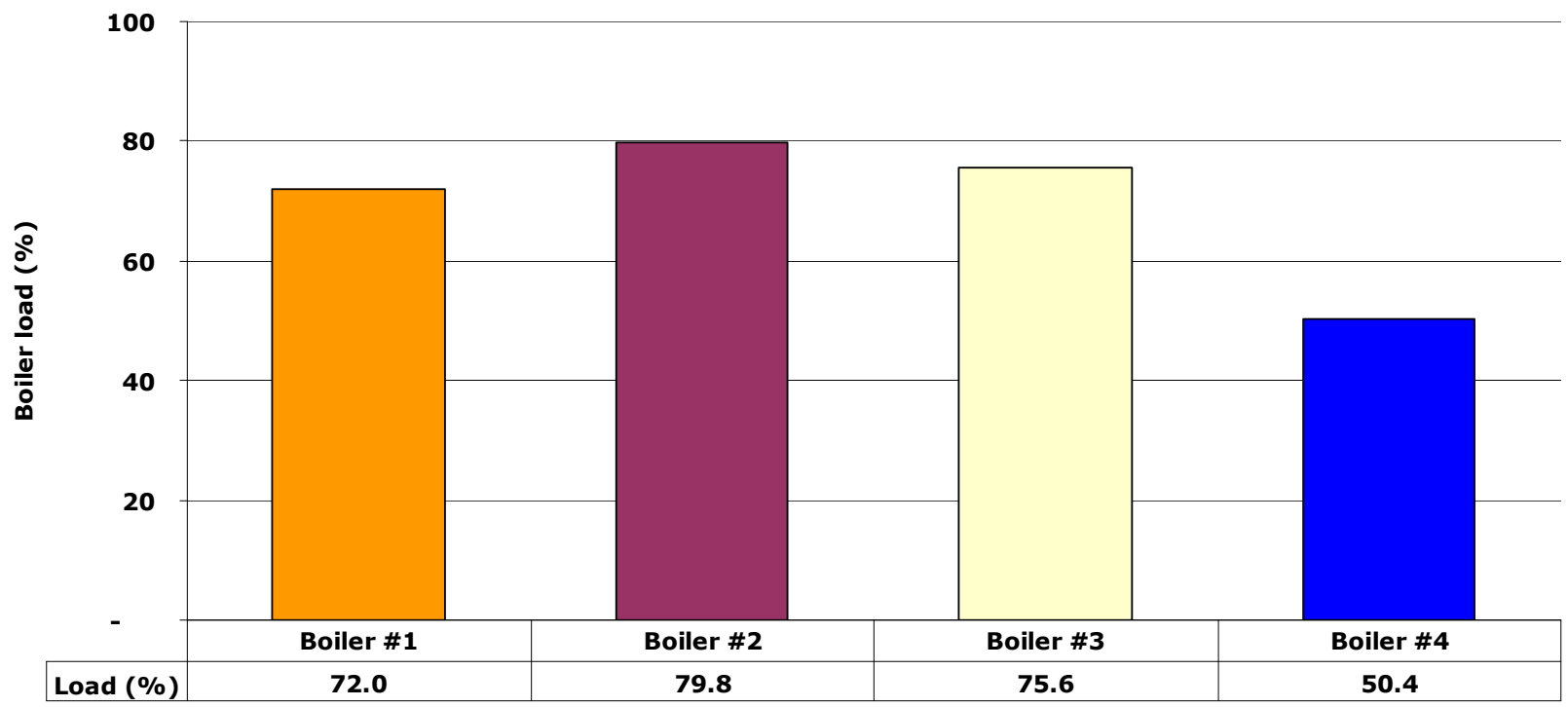

(Total: 1,157,336 MMBtu; \$10,850,000) 
Figure 2b: Average boiler load (\%)

Average steam produced from all the boilers is $\sim 146 \mathrm{klb} / \mathrm{hr}$ which represents $\sim 70 \%$ of full load capacity of the boiler plant. Overall boiler plant efficiency is $\sim 81 \%$. The steam production cost is $\sim$ \$11.5 per klb steam.

Steam is used in the Proteins Conversion plant in the following processes (end use equipment):

- Preheater for Cooker A

- Cooker A

- Cooker B

- Cooker C

- Hydrolyzer

- East feather dryer

- West feather dryer

- Coagulator

- Blood dryer

- SPN finisher

- Hot water exchanger

Based on an energy, steam mass balance and data obtained from the DAS at Proteins Conversion, steam consumption is represented in Figure 3a and 3b. For the purposes of clarity, Figure 3a represents the major users of steam and lumps all other small users into a category called "Minor Users". Figure $3 b$ then further breaks down the minor users into each individual end-use. Steam used in deaerator and other losses are represented as the "Other" category in Figure $3 b$. 


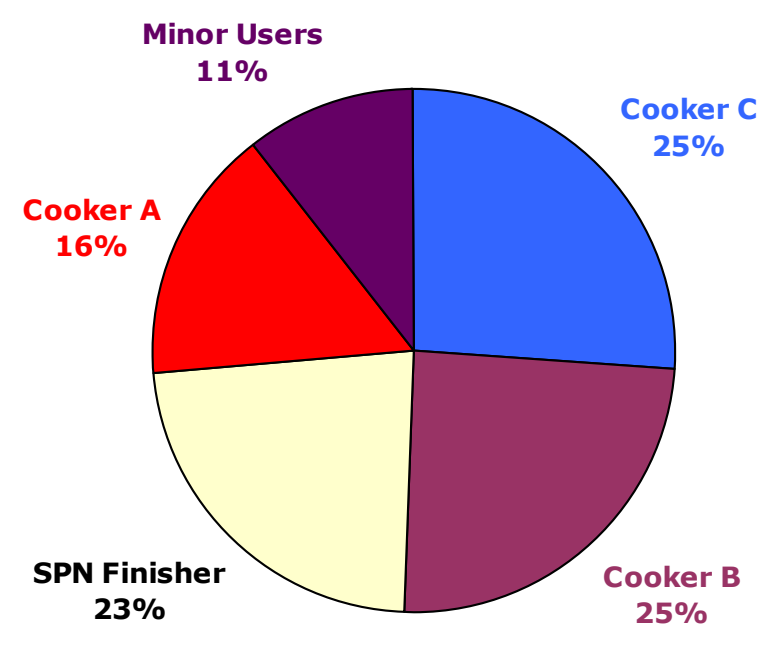

Figure 3a: Major steam users

(Total: $145,560 \mathrm{lb} / \mathrm{hr} ; \$ 1,675 / \mathrm{hr}$ )

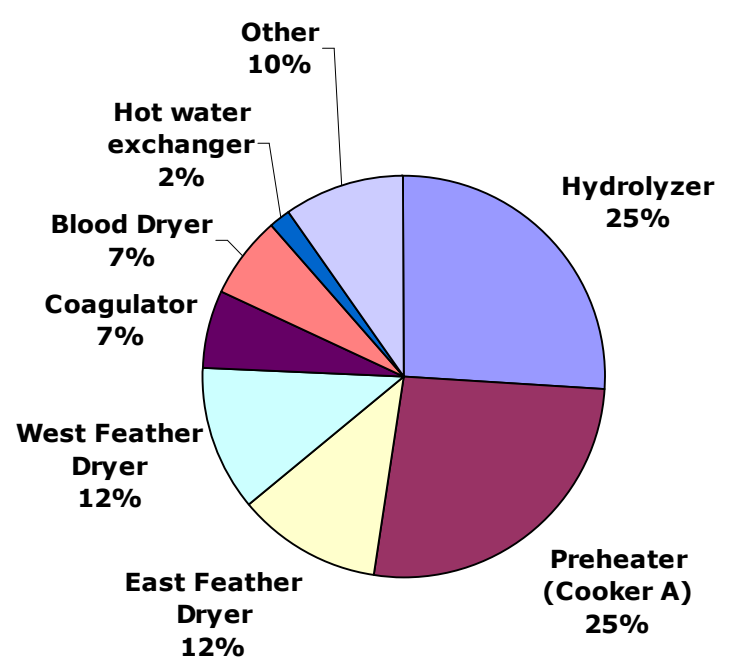

Figure 3b: Minor steam users

(Total: $15,300 \mathrm{lb} / \mathrm{hr} ; \$ 176 / \mathrm{hr}$ )

Table 3 presents the detailed tabulated data that is presented in Figures $3 \mathrm{a}$ and $3 \mathrm{~b}$. This is the best possible information that was derived based on the DAS historian, plant personnel experience and nameplate information. If additional sub-metering is incorporated in the plant, this table and the figures can be refined for further accuracy.

Table 2: $\quad$ Proteins Conversion Annual Steam Usage Breakdown 


\begin{tabular}{|c|c|c|c|c|}
\hline \multirow{2}{*}{ End Use } & Steam & Energy & Cost & $\%$ of Total \\
\hline & (lb/hr) & (MMBtu) & (\$/hr) & $(\%)$ \\
\hline Cooker C & 37,983 & 246,131 & 437 & 26.1 \\
\hline Cooker B & 35,684 & 231,231 & 410 & 24.5 \\
\hline SPN Finisher & 33,590 & 217,663 & 386 & 23.1 \\
\hline Cooker A & 22,996 & 149,013 & 264 & 15.8 \\
\hline Hydrolyzer & 4,000 & 25,920 & 46 & 2.7 \\
\hline Preheater (Cooker A) & 4,000 & 25,920 & 46 & 2.7 \\
\hline East Feather Dryer & 1,776 & 11,508 & 20 & 1.2 \\
\hline West Feather Dryer & 1,776 & 11,508 & 20 & 1.2 \\
\hline Coagulator & 1,000 & 6,480 & 12 & 0.7 \\
\hline Blood Dryer & 1,000 & 6,480 & 12 & 0.7 \\
\hline Hot water exchanger & 250 & 1,620 & 3 & 0.2 \\
\hline Other & 1,505 & 9,753 & 17 & 1.0 \\
\hline Total & 145,560 & 943,229 & 1,674 & 100.0 \\
\hline
\end{tabular}

\section{Prepared Foods}

Steam is produced by a $800 \mathrm{hp}$ natural gas fired fire-tube boiler in the Prepared Foods plant. Although the plant operates $~ 5,616$ hours (18 hrs, 6 days/week), the boiler runs continuously all year round. The nameplate information for the boiler is as follows:

Model Number: PFTA 800-4G150S

Manufacturer: Stone Johnston Boiler Company

Capacity: $800 \mathrm{hp}(\sim 27,000 \mathrm{lb} / \mathrm{hr}$ steam $)$

Pressure Rating: 150 psig

Number of passes: 4

Blower: $20 \mathrm{hp}$ 
Average steam generation from this boiler is $\sim 17,000 \mathrm{lb} / \mathrm{hr}$. Steam is used for cooking (Lines 1, 2, 3 and 7) and to make high pressure hot water for cleaning and sanitation purposes. Prepared Foods also receives $\sim 50-60 \mathrm{Mgal} / \mathrm{day}$ of hot water from the Proteins Conversion plant. Prepared Foods also has $\sim 35-50 \mathrm{~kW}$ of electric hot water boilers for providing hot water for personnel sanitation purposes.

A large amount of natural gas in the Prepared Foods plant is used by the Fulton Paratherm fluid heaters and the direct-fired ovens and fryers. Table 4 provides information on the individual lines 1-8 and the different fryer and oven combinations that exist. Note that "Direct" firing implies natural gas is burned to provide the thermal energy without the use of an indirect fluid medium (Paratherm). All the information gathered in this table is compiled from the plant visit and extensive communication with plant personnel.

Table 3: $\quad$ Fryers and Ovens in Lines 1-8 (Prepared Foods Plant)

\begin{tabular}{|c|c|c|c|c|c|c|c|}
\hline \multirow{3}{*}{ Line \# } & \multicolumn{3}{|c|}{ Fryer } & \multicolumn{4}{|c|}{ Oven } \\
\hline & \multirow{2}{*}{ Type } & \multirow{2}{*}{ Fulton Unit } & \multirow{2}{*}{$\begin{array}{l}\text { Capacity } \\
\text { (MMBtuh) }\end{array}$} & \multirow{2}{*}{ Type } & \multirow{2}{*}{ Style } & \multirow{2}{*}{ Fulton Unit } & \multirow{2}{*}{$\begin{array}{l}\text { Capacity } \\
\text { (MMBtuh) }\end{array}$} \\
\hline & & & & & & & \\
\hline 1 & Indirect & PR151 & 3.5 & Direct & MPO & - & 8.0 \\
\hline 2 & Indirect & PR151 & 3.5 & Direct & MPO & - & 8.0 \\
\hline 3 & Direct & - & 4.0 & Direct & JSO & - & 4.0 \\
\hline 4 & Indirect & PR651 & 4.0 & - & - & - & - \\
\hline 5 & Indirect & PR651 & 4.0 & - & - & - & - \\
\hline 6 & Indirect & PR651 & 4.0 & - & - & - & - \\
\hline 7 & - & - & - & Indirect & $\mathrm{GCO}$ & PR751 & 4.0 \\
\hline 8 & & & IQF I & No Frye & ven & & \\
\hline
\end{tabular}

MPO - MultiPurpose Oven

JSO - Jet Stream Oven

GCO - Gyro Compact Oven (spiral) 


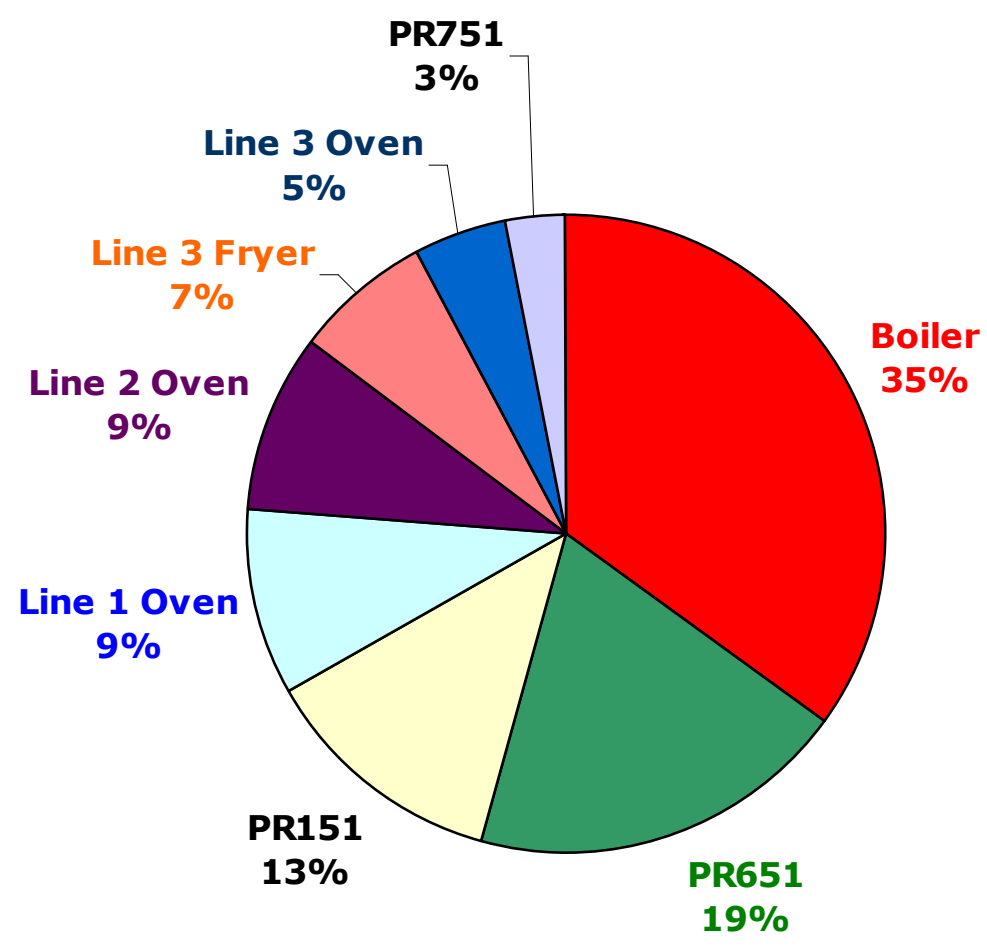

Figure 4 presents the natural gas usage breakdown in the Prepared Foods plant and Table 5 provides more detailed information in the tabulated format.

Figure 4: Natural gas usage breakdown in Prepared Foods plant (Annual Total: 523,600 MMBtu; \$4,900,000) 


\begin{tabular}{|l|r|r|r|r|}
\hline \multirow{2}{*}{ End Use } & Natural Gas & \multicolumn{1}{c|}{ Energy } & \multicolumn{1}{c|}{ Cost } & \multicolumn{1}{c|}{ \% of Total } \\
\cline { 2 - 5 } & \multicolumn{1}{c|}{$\mathbf{( s c f h )}$} & $\mathbf{( M M B t u )}$ & \multicolumn{1}{c|}{$\mathbf{( \$ \mathbf { h r } )}$} & \multicolumn{1}{c|}{$\mathbf{( \% )}$} \\
\hline Boiler & 20,456 & 183,852 & 196.7 & 35.1 \\
\hline PR651 & 11,139 & 100,114 & 107.1 & 19.1 \\
\hline PR151 & 7,310 & 65,700 & 70.3 & 12.5 \\
\hline Line 1 Oven & 8,354 & 48,137 & 51.5 & 9.2 \\
\hline Line 2 Oven & 8,354 & 48,137 & 51.5 & 9.2 \\
\hline Line 3 Fryer & 4,177 & 37,543 & 40.2 & 7.2 \\
\hline Line 3 Oven & 4,177 & 24,069 & 25.8 & 4.6 \\
\hline PR751 & 2,785 & 16,046 & 17.2 & 3.1 \\
\hline Total & $\mathbf{6 6 , 7 5 2}$ & $\mathbf{5 2 3 , 5 9 8}$ & $\mathbf{5 6 0 . 3}$ & $\mathbf{1 0 0 . 0}$ \\
\hline
\end{tabular}

Table 5: Prepared Foods Plant Annual Natural Gas Usage Breakdown

\section{West Kill Plant}

Saturated steam (@100 psig) is produced by two 150 hp natural gas fired fire-tube boilers in the West Kill plant. Typically, only one boiler or less is required to provide all the steam needed in the plant. Hence, one of the boilers remains in warm standby mode. The plant operates $\sim 4,590$ hours (17 hrs, 5 days/week and 10 saturdays). The boilers operate during production as well as plant washdown/sanitation cycles. The nameplate information for the boilers is as follows:

\section{Boiler \#1}

Manufacturer: William \& Davis

Capacity: $150 \mathrm{hp}(\sim 5,100 \mathrm{lb} / \mathrm{hr}$ steam $)$

Pressure Rating: 150 psig 
Number of passes: 3

\section{$\underline{\text { Boiler \#2 }}$}

Model Number: 5-5-751-S150-M

Manufacturer: Superior Boiler Works

Capacity: $150 \mathrm{hp}(\sim 5,100 \mathrm{lb} / \mathrm{hr}$ steam $)$

Pressure Rating: 150 psig

Number of passes: 3

No instrumentation or sub-metering is available in the West Kill plant. Based on discussions, average steam generation in the West Kill plant is expected to be $\sim 3,000 \mathrm{lb} / \mathrm{hr}$. Steam is used for the following processes in the plant:

- Scalding (direct steam injection)

- Hot water for paw peeler (Steam-Water heat exchanger)

- Personnel sanitation and handwash (Steam-Water heat exchanger)

- Washdown water for plant sanitation (Holding tank - steam coil) 
The West Kill plant also receives hot water from the Proteins Conversion plant and an estimate of that usage is provided in Appendix A1. Figure 5 presents the corresponding energy (natural

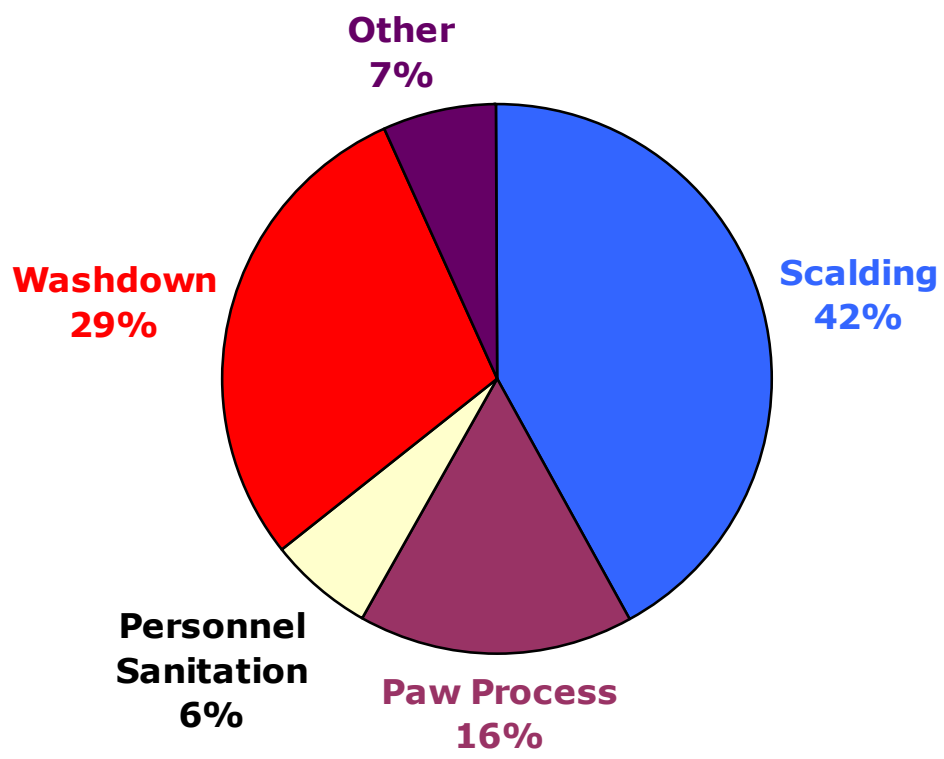

gas) usage allocation in the West Kill plant and Table 6 provides more detailed information in the tabulated format.

Figure 5: Energy (natural gas) usage breakdown in West Kill plant

(Annual Total: 26,730 MMBtu; \$250,600)

\begin{tabular}{|c|c|c|c|c|}
\hline \multirow{2}{*}{ End Use } & Steam & Energy & Cost & $\%$ of Total \\
\hline & (lb/hr) & (MMBtu) & $(\$ / h r)$ & $(\%)$ \\
\hline Scalding & 1,950 & 11,188 & 28.6 & 41.9 \\
\hline Paw Process & 750 & 4,303 & 11.0 & 16.1 \\
\hline Personnel Sanitation & 150 & 1,643 & 4.2 & 6.1 \\
\hline Washdown & 3,300 & 7,796 & 48.3 & 29.2 \\
\hline Other & & 1,800 & 4.6 & 6.7 \\
\hline Total & & 26,730 & & 100.0 \\
\hline
\end{tabular}

Table 6: West Kill Plant Annual Energy (Natural Gas) Usage Breakdown 


\section{East Kill Plant}

Saturated steam (@90 psig) is produced by one 200 hp natural gas fired fire-tube boiler in the East Kill plant. The plant operates $\sim 4,320$ hours ( $16 \mathrm{hrs,} 5$ days/week and 10 saturdays). The boiler operates during regular plant operation as well as the plant washdown/sanitation cycle. The nameplate information for the boiler is as follows:

Manufacturer: Superior Boiler Works

Capacity: $200 \mathrm{hp}(\sim 6,700 \mathrm{lb} / \mathrm{hr}$ steam $)$

Pressure Rating: 125 psig

Number of passes: 3

No instrumentation or sub-metering is available in the East Kill plant. Based on discussions, average steam generation in the East Kill plant is expected to be $\sim 2,000 \mathrm{lb} / \mathrm{hr}$. Steam is used for the following processes in the plant:

- Scalding (direct steam injection)

- Process hot water (Steam-Water heat exchanger)

- Personnel sanitation and handwash (Steam-Water heat exchanger)

- Washdown hot water for plant sanitation 
The East Kill plant also receives hot water from the Proteins Conversion plant and an estimate of that usage is provided in Appendix A1. Figure 6 presents the corresponding energy (natural gas)

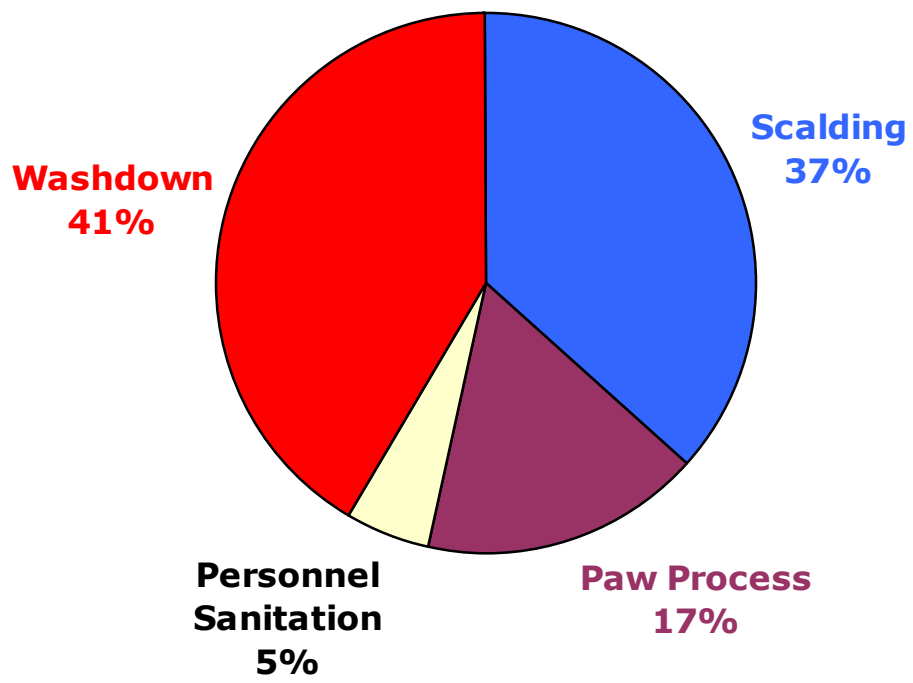

usage allocation in the East Kill plant and Table 7 provides more detailed information in the tabulated format.

Figure 6: Energy (natural gas) usage breakdown in East Kill plant

(Annual Total: 18,813 MMBtu; \$176,300)

\begin{tabular}{|l|r|r|r|r|}
\hline \multirow{2}{*}{ End Use } & \multicolumn{1}{c|}{ Steam } & \multicolumn{1}{c|}{ Energy } & \multicolumn{1}{c|}{ Cost } & \multicolumn{1}{c|}{ \% of Total } \\
\cline { 2 - 5 } & $\mathbf{( l b / h r )}$ & $\mathbf{( M M B t u )}$ & \multicolumn{1}{c|}{$\mathbf{( \$ / h r )}$} & \multicolumn{1}{c|}{$\mathbf{( \% )}$} \\
\hline Scalding & 1,238 & 6,898 & 19.3 & 36.7 \\
\hline Paw Process & 563 & 3,135 & 8.8 & 16.7 \\
\hline Personnel Sanitation & 225 & 941 & 2.6 & 5.0 \\
\hline Washdown & 2,813 & 7,839 & 43.9 & 41.7 \\
\hline Total & & $\mathbf{1 8 , 8 1 3}$ & & $\mathbf{1 0 0 . 0}$ \\
\hline
\end{tabular}

Table 7: East Kill Plant Annual Energy (Natural Gas) Usage Breakdown 


\section{Truck Shop}

The Truck shop uses natural gas and waste motor oil to provide space heating during the winter months. The shop has a combination of equipment to provide space heat to personnel. That includes:

- Floor heating

- Hot water loop

- Waste oil heater with blower

Floor heating and hot water loop (space heating) is provided by natural gas. The Truck Shop operates $\sim 7,488$ hours ( 24 hrs, 6 days/week). Nevertheless, heating is required for only $\sim 2,880$

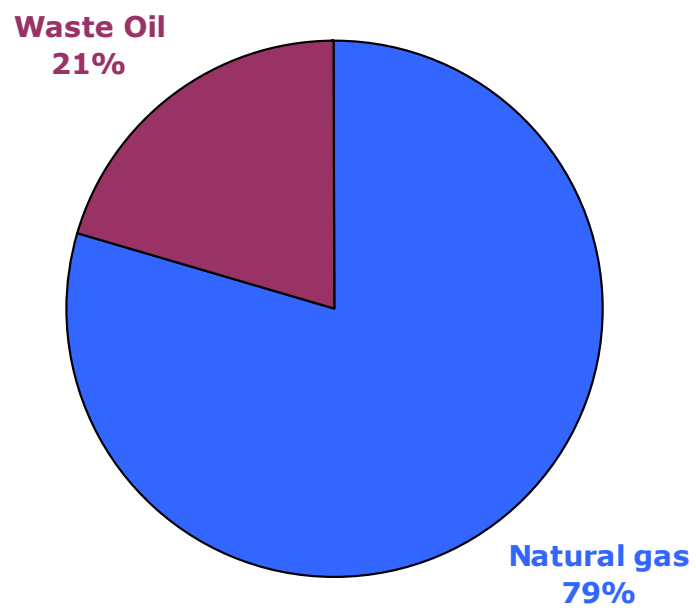

hours. Figure 7 provides a breakdown of fuel energy supplied. Note that "no dollar cost" is associated with the waste motor oil.

Figure 7: Fuel breakdown in Truck Shop

(Annual Total: 8,335 MMBtu; \$62,000) 


\section{ENERGY CONSERVATION MEASURES}

Almost no change can be expected if there are no returns on the financial side. Energy optimization of the Mt. Pleasant, TX site operations will lead to significant energy and cost savings. This section provides information on the energy conservation measures (ECM) or savings opportunities that may be possible at the Mt. Pleasant, TX site. All of these opportunities were evaluated using the US DOE Steam BestPractices Tools and some proprietary models. All the opportunities were based on sound engineering practices and it was ensured that none of the opportunities would sacrifice reliability and safety of the chicken processing operation at the Mt. Pleasant, TX site. Each of the ECMs are described first and then tabulated for summary purposes. The ECMs are grouped together by individual plants and are given a simple code to cross reference them easily in the summary table.

\section{PROTEINS CONVERSION PLANT ECMS}

The US DOE Steam System Assessment Tool (SSAT) was used to model the steam generation, distribution, end-use and condensate return systems at the Proteins Conversion plant. A similar exercise was completed on the other plants also. Nevertheless, the biggest impact is found to be at the Proteins Conversion plant due to its significantly larger steam generation and energy usage compared to the other plants at the Mt. Pleasant, TX site.

Figure 8 provides a snapshot of the current steam system operation in the SSAT at the Proteins Conversion plant. Once the system was modeled in SSAT, then several individual projects were turned "ON" to evaluate potential energy and cost savings that may be possible from the system 
operations. Note that the SSAT also evaluates emissions reductions for each of the individual ECMs.

\section{ECM PC1: Implement automatic oxygen trim controllers}

Currently, based on flue gas analysis it is found that boilers operate between $4.5-5 \%$ excess oxygen levels. This is based on a positioning control that is tuned periodically (at least once every two years). Industry bestpractices implement an automatic oxygen trim controller that can maintain oxygen levels in much tighter controls - 2-3\% excess oxygen. The SSAT model predicts that reducing oxygen levels to $3 \%$ would lead to $\sim 0.9 \%$ reduction in natural gas usage. 


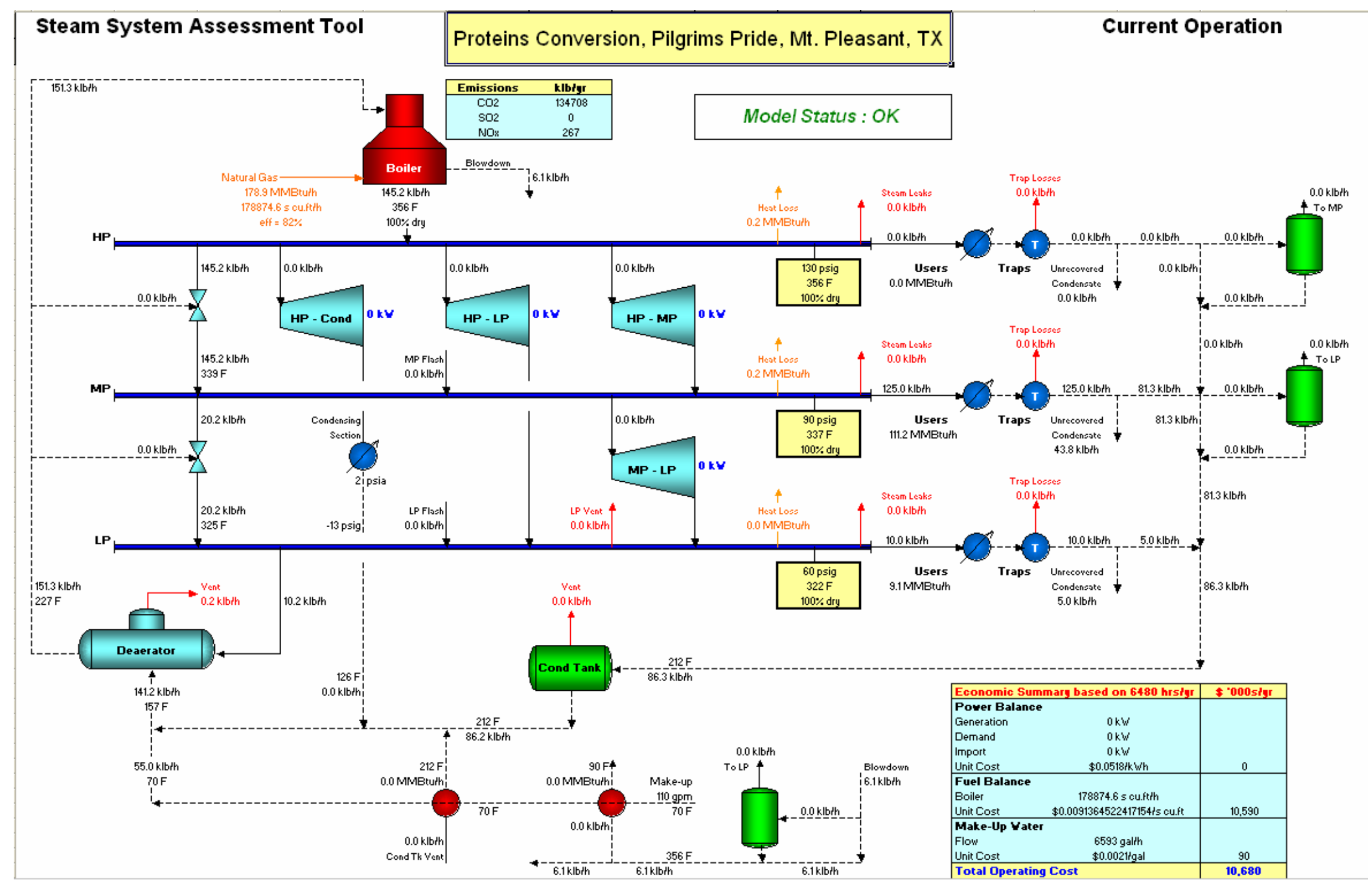


Figure 8: SSAT Model - Proteins Conversion, Pilgrims Pride, Mt. Pleasant, TX - current operation 


\section{ECM PC2: Implement heat recovery from boiler stacks}

There have been significant technology developments in the area of economizers and especially, condensing economizers. The boiler plant has a relatively high condensate return. Hence, feedwater economizers may not be the most productive. Nevertheless, the site requires a significant amount of hot water. Hence, implementing condensing economizers would be very beneficial. There are some challenges that have to be overcome including the fact that each boiler has an individual stack. Secondly, the heat recovery exchanger can introduce backpressure, so some engineering effort is needed to analyze if the current fan power would be sufficient.

It is recommended that instead of recovering heat from all the boilers, boilers \#1 and \#2 be targeted for condensing stack heat recovery. This is because those two boilers operating at full load (3,500 hp) can account for almost $80 \%$ of the total steam demand. The stacks of the two boilers are also next to each other and ducting would not be complex. Hot water temperatures at $\sim 140^{\circ} \mathrm{F}$ can be achieved with condensing stack heat recovery units. Assuming city water is $\sim 70^{\circ} \mathrm{F}$, heat recovery from these two stacks could make $\sim 275 \mathrm{gpm}$ of hot water.

An alternate approach to condensing heat recovery may be sensible heat recovery from the stacks. Assuming city water is $\sim 70^{\circ} \mathrm{F}$, heat recovery from the two stacks could make $\sim 75 \mathrm{gpm}$ of hot water. 


\section{ECM PC3: Reduce boiler blowdown}

Boiler blowdown maintains appropriate boiler water chemistry but is a loss to the system. Conductivity readings of the boiler water sample show that plant personnel have been doing a very good job in maintaining boiler water chemistry. In fact the conductivity results show that boiler water conductivity $(2,500)$ is at the low end of the allowable range $(2,500-3,500)$. This is because there is a significant amount (>70\%) of condensate returned directly to the boiler thereby requiring a lesser amount of blowdown than current operation. Reducing blowdown from $3.2 \%$ (current operation) to $2 \%$ can lead to $\sim 0.4 \%$ energy savings.

\section{ECM PC4: Reduce boiler shell losses}

A fire-tube boiler will have lower shell losses when compared to a water-tube boiler. But if proper insulation is not maintained on the fire-tube boilers, these losses can be as high $1 \%$ of boiler heat duty. Boiler surface insulation can be improved at the Proteins Conversion plant. Preliminary estimates, using the 3EPLus insulation software indicate that potential energy savings of $\sim 1,000-1,500 \mathrm{MMBtu} / \mathrm{yr}$ per boiler can be achieved by improving the insulation on the boilers.

\section{ECM PC5: Implement blowdown heat recovery}


Surface blowdown from the boilers is saturated water $\left(350^{\circ} \mathrm{F}\right)$ at $120 \mathrm{psig}$ and has significant thermal energy. The blowdown water can first be flashed in a flash tank operating slightly above the deaerator pressure. The flash steam can be sent to the deaerator and the remainder liquid water can heat the make-up water before being dumped into the sewer. A schematic of this

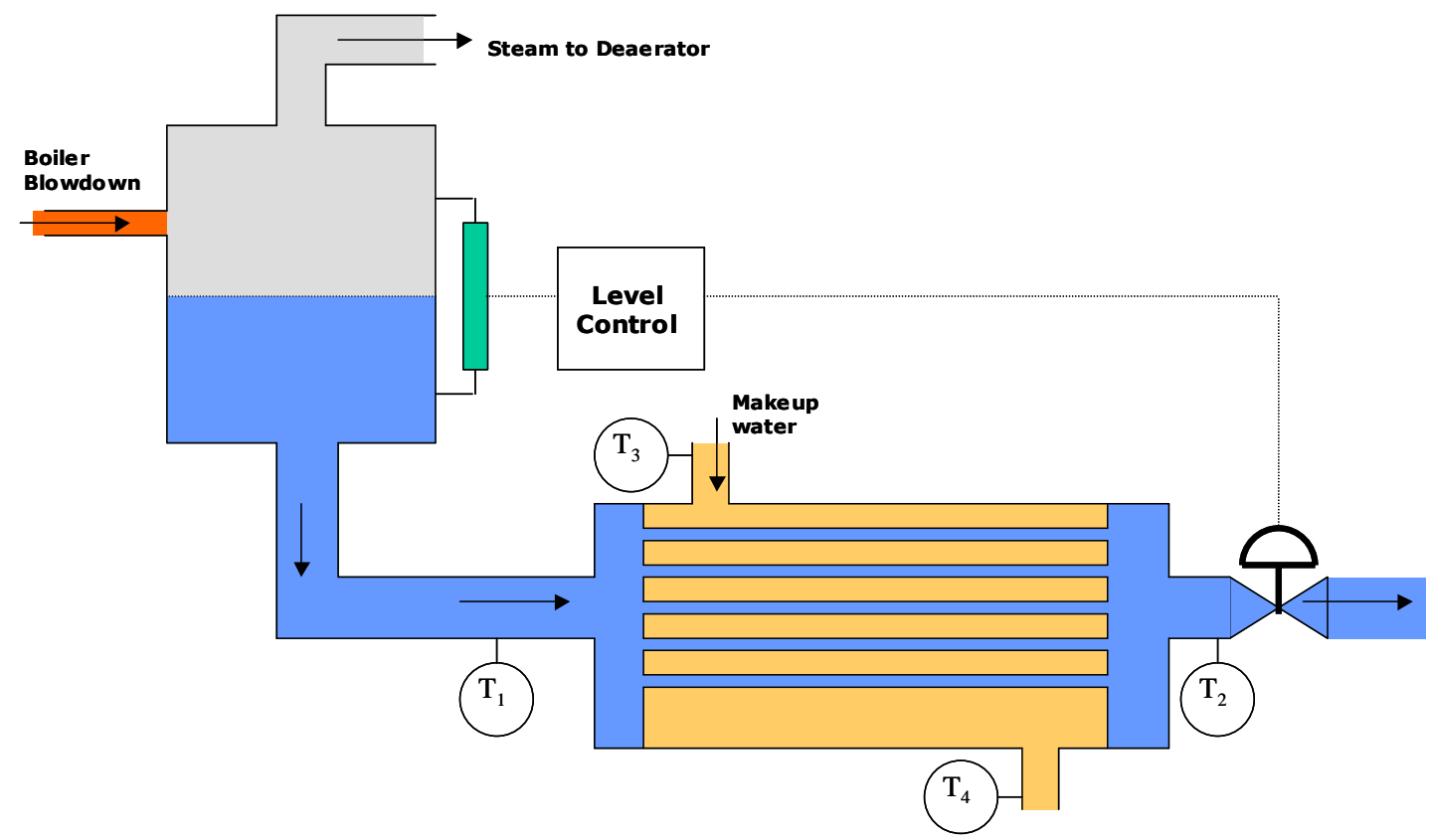

configuration is given in Figure 9. Based on the SSAT model, implementing blowdown heat recovery provides $0.9 \%$ energy savings ( 1.6 MMBtu/hr).

Figure 9: Schematic of implementation of blowdown heat recovery

\section{ECM PC6: Reduce steam leaks}

There are several areas where steam leaks are prevalent and they can be curtailed. Most of these leaks are the exhaust vents downstream of the end-uses. All these lines should have condensate returning back to the boiler plant. Nevertheless, all these vent valves have been opened to allow for a higher throughput through the cookers, feather dryers, blood dryer. This results in a 
significant loss of steam. Most of these vent pipes are at least 1" in size and some of them are 2". Based on calculations (Napier's choked flow equation), a 1" pipe, with 90 psig upstream pressure, can loose $\sim 2.5 \mathrm{klb} / \mathrm{hr}$ of saturated steam. A cumulative steam loss based on distribution system walk-through was estimated to be $\sim 5 \mathrm{klb} / \mathrm{hr}$. This loss can be virtually eliminated by shutting off all the condensate return vent valves near the end-uses.

\section{ECM PC7: Improve overall system insulation}

In any Proteins Conversion plant, insulation is extremely difficult to maintain and considering that the environment is not conducive to frequent repairs, the plant in Mt. Pleasant, TX has done a good job on maintaining insulation. Nevertheless, there are several areas, especially steam lines feeding heat exchangers, heat exchanger end covers, valves, condensate return lines, etc. that need insulation or do not have adequate insulation. The 3EPlus insulation software was used to model bare pipes as well as surfaces to come up with an aggregate value for heat loss from these uninsulated sections. At a conservative level, the study predicts energy savings of $\sim 2 \mathrm{MMBtu} / \mathrm{hr}$ that can be achieved in the Proteins Conversion plant by improving insulation. A detailed insulation audit would be recommended going forward which could tag the individual pipes, valves, heat exchangers and identify the optimum economic thickness for insulating these components.

\section{ECM PC8: Improve condensate recovery system}

Condensate return in the Proteins Conversion plant is unique. This is because there are no condensate tanks. Condensate at high pressure (90 psig) returns to the boiler directly. This is extremely effective because it virtually eliminates thermal losses. But it does introduce several 
other operating issues that may make the system operation complex and difficult to control. Condensate is saturated liquid and it flashes at the smallest amount of pressure drop. This can introduce a tremendous back-pressure in the condensate return line resulting in higher operating pressures in the end-use equipment and reducing operational capacity. This is currently one of the issues that the Proteins Conversion is facing with the cookers and feather dryers. Condensate vent valves have been cracked open to allow for eliminating this back-pressure. But this results in steam loss (as described in ECM PC6) and valuable condensate loss. Another problem that exists is the condensate flowmeter doesn't read accurately because there is water hammering and reverse flow in the condensate return header. The SSAT model predicts $~ 2.2 \mathrm{MMBtu} / \mathrm{hr}$ energy savings to result from an additional $10 \%$ of condensate to be returned to the boiler plant. In addition to those savings, water savings of the order of $15 \%$ can be achieved. This can be achieved by having a common condensate tank in the end-use area, allowing condensate to flash and then pumping the return condensate back to the boilers/deaerator.

\section{ECM PC9: Flash HP condensate to produce MP steam}

As mentioned in ECM PC8, high pressure (HP) condensate (90 psig) is returned to the boiler plant. But if a secondary flash tank at an intermediate pressure (60 psig) is incorporated, then the flash steam from this tank can offset some of the HP steam usage. There are several users that can use steam in the 60 psig range including preheaters, hydrolyzer, offal reheater, etc. The SSAT model predicts $\sim 2.8 \mathrm{MMBtu} / \mathrm{hr}$ energy savings possible by flashing 90 psig condensate to $60 \mathrm{psig}$ steam and using this steam to provide for some of the end-users. Additionally, there is water savings since the overall steam generation is reduced. 


\section{ECM PC10: Preheat cookers B and C feed streams}

Cooker A has a preheater and comparing the steam loads on cookers B and C with cooker A (Table 3), it is evident that cooker A uses 35\% less steam than cooker B or C. The preheater of cooker $\mathrm{A}$ is steam driven and does consume some steam but it is still marginal. Implementing preheaters for cookers $\mathrm{B}$ and $\mathrm{C}$ would result in significant energy and cost savings. There are several advantages of implementing preheaters:

- $\quad 20 \%$ reduced energy (steam) consumption for the cooking process

- Flash steam from high pressure condensate (@90 psig) can be used in the preheaters

- Additional prime heat transfer area now becomes available in the cooker for the cooking process

- Higher cooking rates can be achieved

\section{ECM PC11: Install a backpressure steam turbine}

There are several places where low pressure (30 psig or less) steam is needed in the plant deaerator, hot water generation, etc. Steam at high pressure is letdown through pressure reducing valves to produce this low pressure steam. An energy-saving alternative would be to use a backpressure steam turbine that exhausts at the low pressure. This serves as a pressure reduction device and also provides shaft power. The shaft power can be used to drive a mechanical device such as the boiler feedwater pump, combustion fan, etc. This is a special case of cogeneration, wherein energy is supplied in the boiler to produce steam and that steam provides both the thermal energy and mechanical shaft power. The SSAT model predicts that $\sim 175 \mathrm{~kW}$ of shaft power can be generated from a backpressure turbine at the Proteins Conversion plant. Note that the gas usage increases by a small amount $-0.4 \%$ to offset the steam turbine enthalpy change. This ECM may not be very favorable for the Mt. Pleasant, TX plant because of the spread between natural gas and electricity prices. 


\section{PREPARED FOODS PLANT ECMS}

The US DOE Steam System Assessment Tool (SSAT) was used to model the steam generation, distribution, end-use and condensate return systems at the Proteins Conversion plant. Once the system was modeled in SSAT, then several individual projects were turned "ON" to evaluate potential energy and cost savings that may be possible from the system operations. Nevertheless, the biggest energy savings opportunities in the Prepared Foods plant are in process waste heat recovery. Figure 10 represents the current operation of the steam system in the Prepared Foods plant. 


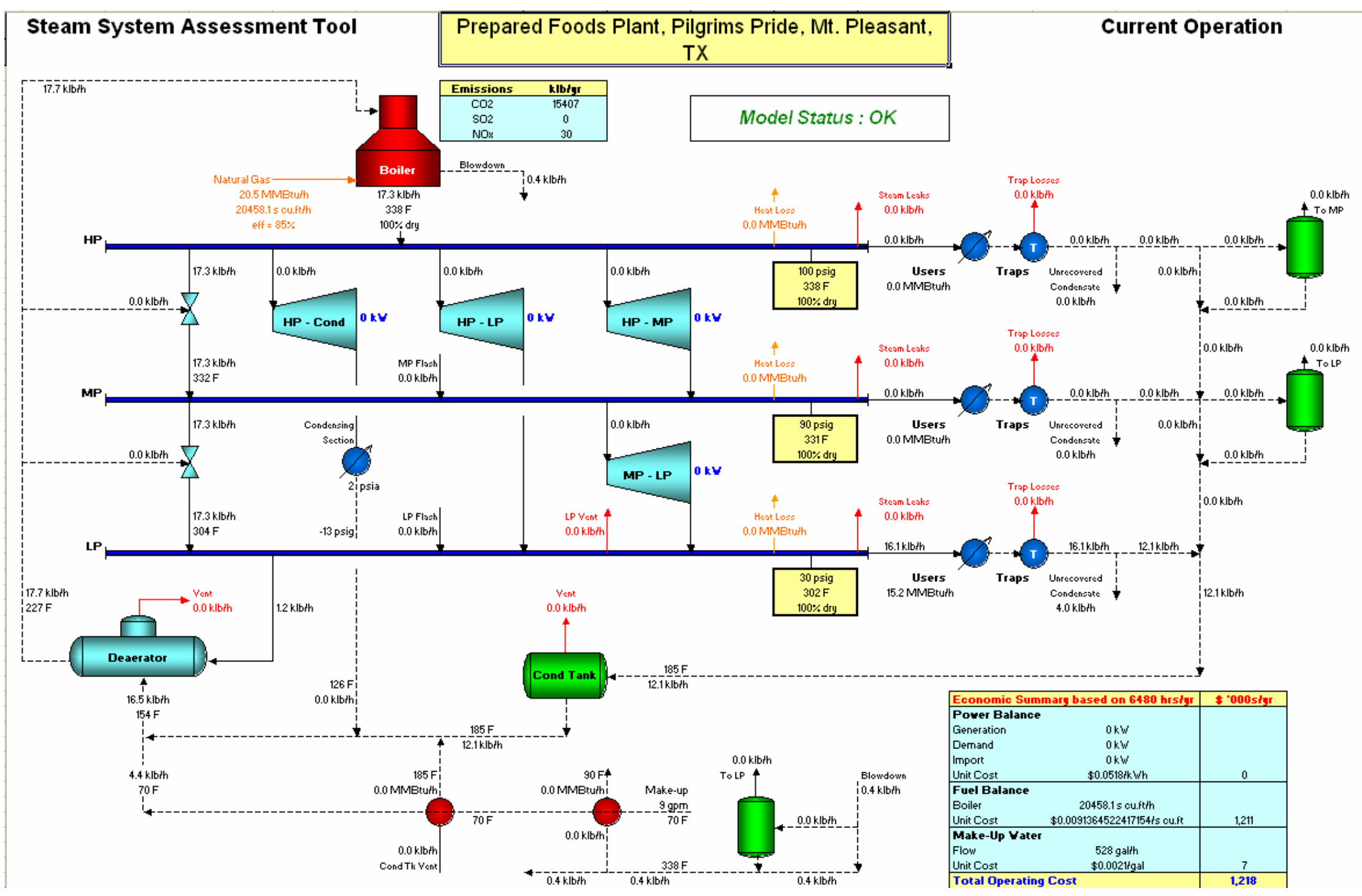


Figure 10: SSAT Model - Prepared Foods Plant, Pilgrims Pride, Mt. Pleasant, TX - current operation 


\section{ECM PF1: Implement automatic oxygen trim controller}

Currently, based on flue gas analysis it is found that the Prepared Foods plant boiler ( $800 \mathrm{hp}$ ) operates between 4-5\% excess oxygen levels. This is based on a positioning control and is tuned periodically (once every year). Industry bestpractices implement an automatic oxygen trim controller that can maintain oxygen levels in much tighter controls $-2-3 \%$ excess oxygen. The SSAT model predicts that reducing oxygen levels to $3 \%$ would lead to $\sim 0.9 \%$ reduction in natural gas usage for the boiler.

\section{ECM PF2: Implement heat recovery from boiler stack}

The site requires a significant amount of hot water. Hence, implementing a condensing economizer would be very beneficial. Hot water temperatures of $\sim 140^{\circ} \mathrm{F}$ can be achieved with a condensing stack heat recovery unit. Assuming city water is $\sim 70^{\circ} \mathrm{F}$, heat recovery from the boiler stack can provide $\sim 35 \mathrm{gpm}$ of hot water. An alternate approach to condensing heat recovery may be sensible heat recovery from the stack. Assuming city water is $\sim 70^{\circ} \mathrm{F}$, heat recovery from the boiler stack could make $\sim 10$ gpm of hot water.

\section{ECM PF3: Implement blowdown heat recovery}

Surface blowdown from the boiler is saturated water $\left(338^{\circ} \mathrm{F}\right)$ at 100 psig and has significant thermal energy. The blowdown water can first be flashed in a flash tank operating slightly above the deaerator pressure. The flash steam can be sent to the deaerator and the remainder liquid water can heat the make-up water before being dumped into the sewer. A schematic of this configuration was given in Figure 9 in the Proteins Conversion section. Based on the SSAT 
model, implementing blowdown heat recovery provides $0.5 \%$ boiler energy savings $(\sim 0.2$ MMBtu/hr) at the Prepared Foods plant.

\section{ECM PF4: Improve steam system insulation}

Although within the Prepared Foods plant, insulation is not an issue due to the food grade prevalent environment, the hot water heat exchanger area, does not have adequate insulation. The 3EPlus insulation software was used to model bare pipes as well as surfaces to come up with an aggregate value for heat loss from these uninsulated sections. At a conservative level, the study predicts energy savings of $\sim 0.1 \mathrm{MMBtu} / \mathrm{hr}$ that can be achieved in the Prepared Foods plant by improving insulation. A detailed insulation audit would be recommended going forward which could tag the individual pipes, valves, heat exchangers and identify the optimum economic thickness for insulating these components.

\section{ECM PF5: Implement heat recovery from process}

The Prepared Foods plant uses a significant amount of natural gas energy for the fryers and ovens (Figure 4). Some of these units are direct fired whereas others have an indirect hot loop (Paratherm fluid). Stack exhaust temperatures for the direct-fired units are $\sim 300^{\circ} \mathrm{F}$ whereas the Fulton boilers that heat the Paratherm fluid exhaust at $\sim 650^{\circ} \mathrm{F}$. All these units operate with $\sim 5 \%$ excess flue gas oxygen. From a combustion efficiency perspective, the direct-fired units are $\sim 84 \%$ efficient whereas the Fulton boilers are only $74 \%$ efficient. This presents a tremendous heat recovery opportunity. There are several options for implementing and using this waste heat. Each of them is briefly described below: 


\section{ECM PF5a: Generate hot water for plant use}

This would be very similar to the boiler stack heat recovery. Implementing a condensing hot water heat exchanger can produce $\sim 140^{\circ} \mathrm{F}$. Assuming city water is $\sim 70^{\circ} \mathrm{F}$, heat recovery from the process heater stacks can provide $\sim 135$ gpm of hot water. An alternate approach to condensing heat recovery may be sensible heat recovery from the stacks. Assuming city water is $\sim 70^{\circ} \mathrm{F}$, heat recovery from all the stacks could make $\sim 40$ gpm of hot water.

\section{ECM PF5b: Operate desiccant dehumidification units}

The Prepared Foods plant needs to maintain very strict ambient parameters including temperature and humidity. The air-handling units manage humidity control by using a refrigerant coil for dehumidification. This can be a very high load especially after the daily sanitation cycle. Implementing a desiccant dehumidifier that uses waste heat from the stacks can offset a significant cooling load. Desiccant units can use temperatures as low as $150^{\circ} \mathrm{F}$ and all the stacks can be used to supply heat to the desiccant units. Based on the current operation and recovering all the stack heat, a COP $\sim 0.4$ (including parasitic losses) can be expected. These desiccant dehumidifiers are commercially available as stand-alone units or can be incorporated within the current air handlers.

\section{ECM PF5c: Operate an absorption unit (Thermosorber)}

An absorption unit such as a Thermosorber is a device that can supply cooling and hot water simultaneously. They can be powered by natural gas, propane, fuel oil, solar heat, or waste heat 
(e.g. engine or boiler exhaust heat). The thermosorber would be the most energy efficient application at the Mt. Pleasant, TX site. By cooling the stacks of the Fulton boiler units from $650^{\circ} \mathrm{F}$ to $250^{\circ} \mathrm{F}$, enough heat is available to power a $150 \mathrm{RT}$ Thermosorber. That is large enough to supply $\sim 125 \mathrm{gpm}$ of hot water at $150^{\circ} \mathrm{F}$ (energy savings of $\sim 5.0 \mathrm{MMBtuh}$ ) and continuous chilled cold water at $44^{\circ} \mathrm{F}$ (150 RT, $\left.325 \mathrm{gpm}\right)$. The thermosorber units would have to be custom built and integrated with the Prepared Foods plant process. A technical article from the "Watt Poultry USA" magazine is included in Appendix 4. It is written by Professor Jatal Mannaperuma of UC Davis and describes an application of the thermosorber at a California poultry processing facility.

\section{ECM PF5d: Operate an absorption chiller}

If cooling only is desired, then a commercially available lithium bromide absorption unit can use waste heat and provide chilled water. The Fulton boiler stacks can provide 3.0 MMBtuh of waste heat and using a single-effect lithium bromide absorption chiller, the plant can produce $\sim 175$ gpm of chilled water.

\section{KILL PLANTS \& TRUCK SHOP ECMS}

The overall fuel usage (natural gas, waste oil) in the Kill plants and the Truck shop is $\sim 3 \%$ of the total Mt. Pleasant, TX site usage. Hence, there are not many energy savings opportunities within each of these plants. Nevertheless, these plants were assessed for energy savings opportunities during the plant-wide energy assessment. The biggest opportunity seemed to be on a site optimization level and that will be discussed in the next section. The ECM's for the East and 
West Kill plants are provided below. The truck shop is very independent and does not have any steam usage and so does not have any ECMs per se.

\section{ECM KP1: Improve insulation}

The hot water heat exchangers and boiler shell insulation seemed to need some level of insulation improvement. The steam lines and the valve bodies would also benefit from insulation. These are not long sections of bare pipes but it would reduce energy loss from the system. Preliminary estimates using 3EPlus indicate $\sim 1 \%$ improvement from upgrading insulation.

\section{ECM KP2: Implement blowdown heat recovery}

Surface blowdown from the boiler is saturated water $\left(338^{\circ} \mathrm{F}\right)$ at $100 \mathrm{psig}$ and has significant thermal energy. The blowdown water can first be flashed in a flash tank operating slightly above the deaerator pressure. The flash steam can be sent to the deaerator and the remainder liquid water can heat the make-up water before being dumped into the sewer. A schematic of this configuration was given in Figure 9 in the Proteins Conversion section. Based on the SSAT model, implementing blowdown heat recovery provides $0.5 \%$ boiler energy savings at the East and West Kill plant.

\section{MT. PLEASANT, TX SITE-LEVEL ECMS}

This section covers the overall site-level ECMs. The ECMs in this section are more directed towards the synergies that may be possible if the overall site can be configured such that flow of energy (heat and cold) can be balanced across all the different plants on the site. This is site level 
(global) energy optimization. This optimization takes into account load profiles, shift cycle times, etc. to identify all the energy savings opportunities at the site. One other big advantage of site-level optimization is increased energy reliability site-wide.

Nevertheless, it has to be noted that implementation of these ECMs is more difficult when compared to the individual plant-level ECMs. This is because:

- These ECMs are more complex and challenging

- Understanding energy savings may require detailed analysis

- Several parties need to be involved

- One or more production plants can be impacted

- Infrastructure may not be available

- Cost center approach (for accounting) may need reconfiguration

\section{ECM SL1: Centralize steam generation}

Currently, all the plants (except the Truck shop) produce their own steam. This allows for a lot of independency but results in inefficiency. A boiler is most optimized when it is run at $80 \%$ or higher full load conditions. The load management strategy that would lead to steam generation optimization should be such that it can be easy to comprehend and implement, minimize any associated risks and can revert to current "business as usual" in the event of upsets. By taking into account all the variables and parameters, constraints, dynamic response times, operator comfort levels, an optimization and load management strategy can be developed. The main facet of this optimization strategy would be to minimize the use of excessive boilers and to increase the operating load on the operating boilers. 
The Proteins Conversion boiler plant has 5,900 hp and the Prepared Foods plant boiler is $800 \mathrm{hp}$. There is enough capacity between the Proteins Conversion boiler plant and the Prepared Foods plant boiler to supply steam to the East and West Kill plants. This would eliminate steam generation at the Kill plants that is typically not as efficient as the Proteins Conversion plant. Once the Proteins Conversion ECMs are implemented this difference in efficiency will further widen leading to a centralized steam generation. This ECM can be implemented in phases wherein only the Kill plants are supplied by steam from the Proteins Conversion plant. Then at a later stage the Prepared Foods plant header can be connected to the site level header system. Apart from energy efficiency and load management optimization, the reliability of the steam system is increased significantly. Maintenance will be streamlined and costs will be reduced. Note that the Kill plants can go to their independent boiler operation in the event of an upset or planned shutdown at the Proteins Conversion plant. This ECM will require significant capital due to building of infrastructure such as site-wide steam header and probably a condensate return system. Currently, plants at the Mt. Pleasant, TX site share only hot water.

\section{ECM SL2: Add central hot water storage capacity}

Based on the plant level ECMs, there is a significant heat recovery possible and some of it is in the form of hot water. All the plants do not operate in the same configuration all the time and usage varies depending on whether they are in the process cycle or sanitation (washdown) phase. This leads into a need for thermal storage. Thermal energy (hot water) can be recovered and stored for later use either in the same plant or in another plant. Strategically, locating water storage tanks can make a big difference. One immediate example is when the Proteins Conversion plant is down on Sunday night, washdown cycles are going on in other plants. If additional hot water storage was available, then the Proteins Conversion plant could fill up this 
tank on Saturday for their use on Sunday when Proteins Conversion is down. Similarly, the demand for hot water varies during the day and if waste heat recovery projects are implemented as mentioned under individual plant ECMs, then additional hot water storage than the current 30,000 gallon tank will be absolutely necessary.

\section{ECM SL3: Reduce overall steam operating pressure}

Steam is only used for heating purposes all across the Mt. Pleasant, TX site. If the steam operating pressure is lowered then it would result in boiler efficiency improvement $(\sim 1 \%)$, reduction in steam leaks and reduction in insulation losses. This is a recommendation that can only be implemented after significant engineering and due-diligence. Significant emphasis should be paid to boilers and their rating conditions, steam system headers, control valves, steam traps and condensate backpressure issues, etc. Nevertheless, the ECM can save energy and fuel cost. Although there may be no capital cost involved, it still would require significant engineering cost before implementation. Do not apply this ECM without further due diligence!

\section{SUMMARY OF ECMS}

Table 8 summarizes all the plant level and site-level ECMs in a tabulated format and provides basic initial cost estimates for implementing the ECMs. All the energy savings estimates are derived from the US DOE Steam tools (SSAT, 3EPLus) and proprietary models. The utility costs that are used in this table are: Electricity - $\$ 0.04790 / \mathrm{kWh}$; Natural gas - \$9.374/MMBtu; Water $\$ 2.10 /$ Mgal. 
Table 8 also provides a way to distinguish ECMs based on complexity by providing a time estimate - Near, Mid and Long-term. The definitions for that terminology are as follows:

- Near term opportunities would include actions that could be taken as improvements in operating practices, maintenance of equipment or relatively low cost actions or equipment purchases.

- Mid term opportunities would require purchase of additional equipment and/or changes in the system such as addition of recuperative air preheaters and use of energy to substitute current practices of steam use, etc. It would be necessary to carryout further engineering and return on investment analysis.

- Long term opportunities would require testing of new technology and confirmation of performance of these technologies under the plant operating conditions with economic justification to meet the corporate investment criteria. 
Table 8: Summary of Energy Conservation Measures (ECMs) at Mt. Pleasant, TX site

\begin{tabular}{|c|c|c|c|c|c|c|c|c|}
\hline \multirow{2}{*}{ Plant } & \multirow{2}{*}{ ECM } & \multirow[t]{2}{*}{ Description } & \multicolumn{3}{|c|}{ Annual Savings } & \multirow{2}{*}{$\frac{\text { Cost }}{\$ K}$} & \multirow{2}{*}{$\begin{array}{c}\text { Payback } \\
\text { years }\end{array}$} & \multirow{2}{*}{ Time } \\
\hline & & & $\$ K$ & MMBtu & MWh & & & \\
\hline \multirow{11}{*}{ 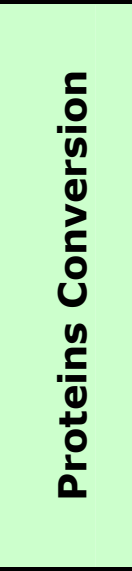 } & PC1 & Implement automatic oxygen trim controllers & 98 & 10,416 & - & 100 & 1.0 & Near \\
\hline & PC2 & Implement heat recovery from boiler stacks & 584 & 62,270 & - & 500 & 0.9 & Long \\
\hline & PC3 & Reduce boiler blowdown & 43 & 4,629 & - & 25 & 0.6 & Near \\
\hline & PC4 & Reduce boiler shell losses & 12 & 1,250 & - & 25 & 2.1 & Near \\
\hline & PC5 & Implement blowdown heat recovery & 98 & 10,416 & - & 75 & 0.8 & Mid \\
\hline & PC6 & Reduce steam leaks & 380 & 40,500 & - & 250 & 0.7 & Mid \\
\hline & PC7 & Improve overall system insulation & 122 & 12,960 & - & 50 & 0.4 & Near \\
\hline & PC8 & Improve condensate recovery system & 134 & 14,256 & - & 200 & 1.5 & Mid \\
\hline & PC9 & Flash HP condensate to produce MP steam & 170 & 18,144 & - & 200 & 1.2 & Mid \\
\hline & PC10 & Preheat cookers B and C feed streams & 448 & 47,736 & - & 500 & 1.1 & Long \\
\hline & PC11 & Install a backpressure steam turbine & 11 & $-4,629$ & 1,134 & 88 & 8 & Long \\
\hline \multirow{9}{*}{$\begin{array}{l}\frac{n}{8} \\
8 \\
0 \\
\frac{0}{4} \\
0 \\
0 \\
\frac{0}{0} \\
\frac{0}{0} \\
\frac{1}{2}\end{array}$} & PF1 & Implement automatic oxygen trim controller & 15 & 1,655 & - & 40 & 2.6 & Near \\
\hline & PF2 & Implement heat recovery from boiler stack & 64 & 6,869 & - & 150 & 2.3 & Long \\
\hline & PF3 & Implement blowdown heat recovery & 10 & 1,123 & - & 25 & 2.4 & Mid \\
\hline & PF4 & Improve steam system insulation & 5 & 562 & - & 10 & 1.9 & Near \\
\hline & \multirow{5}{*}{ PF5 } & Implement heat recovery from process & & & & & & \\
\hline & & a. Generate hot water for plant use & 124 & 13,247 & - & 350 & 2.8 & Long \\
\hline & & b. Operate desiccant dehumidification units & 40 & - & 834 & 178 & 4.5 & Long \\
\hline & & c. Operate an absorption unit (Thermosorber) & 283 & 28,080 & 421 & 375 & 1.3 & Long \\
\hline & & d. Operate an absorption chiller & 36 & - & 756 & 101 & 2.8 & Long \\
\hline \multirow{2}{*}{$\overline{\bar{x}}$} & KP1 & Improve insulation & 4 & 455 & - & 10 & 2.3 & Near \\
\hline & KP2 & Implement blowdown heat recovery & 2 & 228 & - & 30 & 14.0 & Mid \\
\hline \multirow{3}{*}{$\stackrel{0}{\frac{N}{n}}$} & SL1 & Centralize steam generation & 21 & 2,277 & - & 150 & 7.0 & Long \\
\hline & SL2 & Add central hot water storage capacity & 50 & 5,391 & - & 200 & 4.0 & Mid \\
\hline & SL3 & Reduce overall steam operating pressure & 130 & 13,867 & - & 50 & 0.4 & Mid \\
\hline
\end{tabular}




\title{
APPENDIX: II A
}

\section{HOT WATER USAGE CALCULATIONS}

\author{
(supplied by Needham Carswell)
}

\section{PREPARED FOODS}

Based on numbers supplied by Dayne N. $=57,700$ gallons per day $(260$ working days $)=$ 15,002,000 gallons per year

\section{WEST PLANT}

Based on numbers supplied by Roger B. $\quad=167,350$ gallons per day

Based on meter readings $(5-8-02$ to $5-7-03)=167,308$ gallons per day

Average $=167,329$ gallons per day $(260$ working days $)=43,505,540$ gallons per year

\section{EAST PLANT}

Based on numbers supplied by Tommy B. $=51,600$ gallons per day

Based on meter readings (5-8-02 to 5-7-03) $=80,347$ gallons per day Average $=65,974$ gallons per day $(260$ working days $)=17,153,240$ gallons per year

\section{PET FOOD}

Based on meter readings $(5-8-02$ to $5-7-03)=16,000$ gallons per week $(52$ weeks $)=832,000$ gallons per year 


\section{APPENDIX: IIB}

\section{PROTEINS CONVERSION BOILERS COMBUSTION EFFICIENCY}

Boiler combustion efficiencies are calculated from stack gas temperatures and flue gas analysis. These were obtained from plant records of annual burner maintenance and tune-ups. Actual

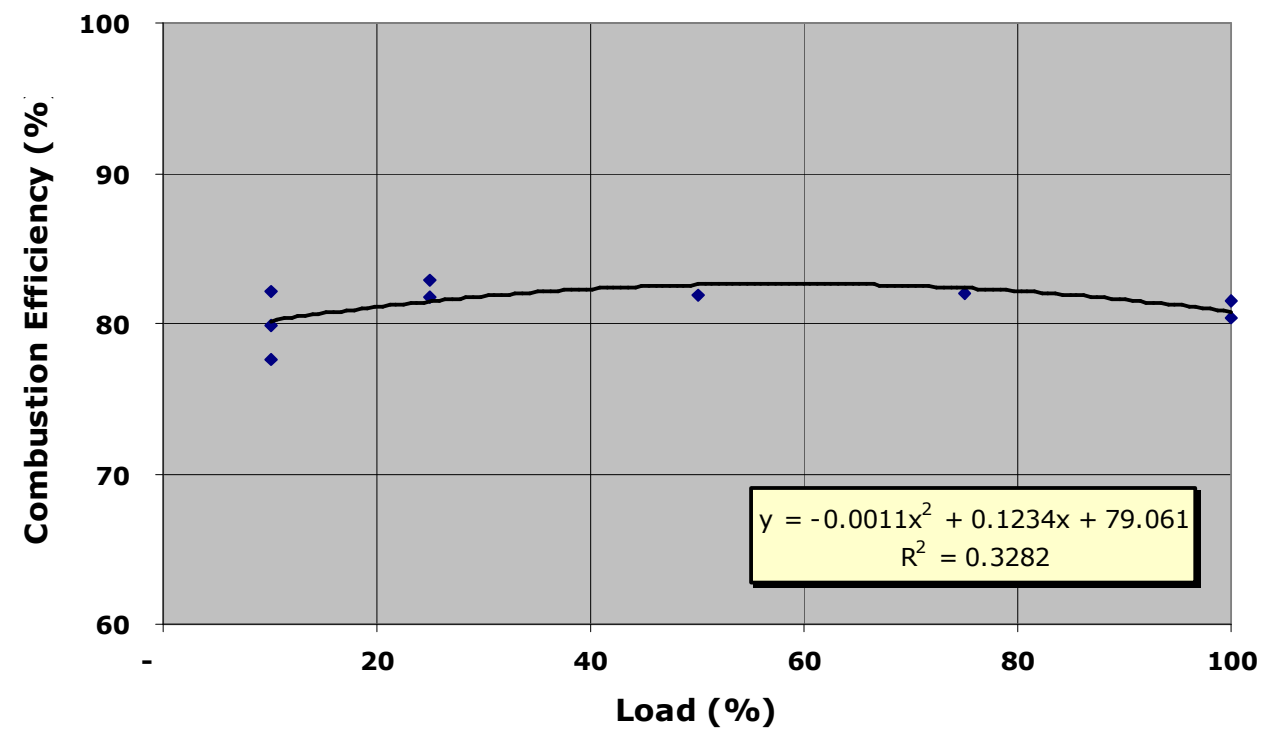

boiler efficiency will be lower than these values due to blowdown losses and shell (radiation) losses.

Figure A1a: Boiler 1 (2,000 hp) combustion efficiency 


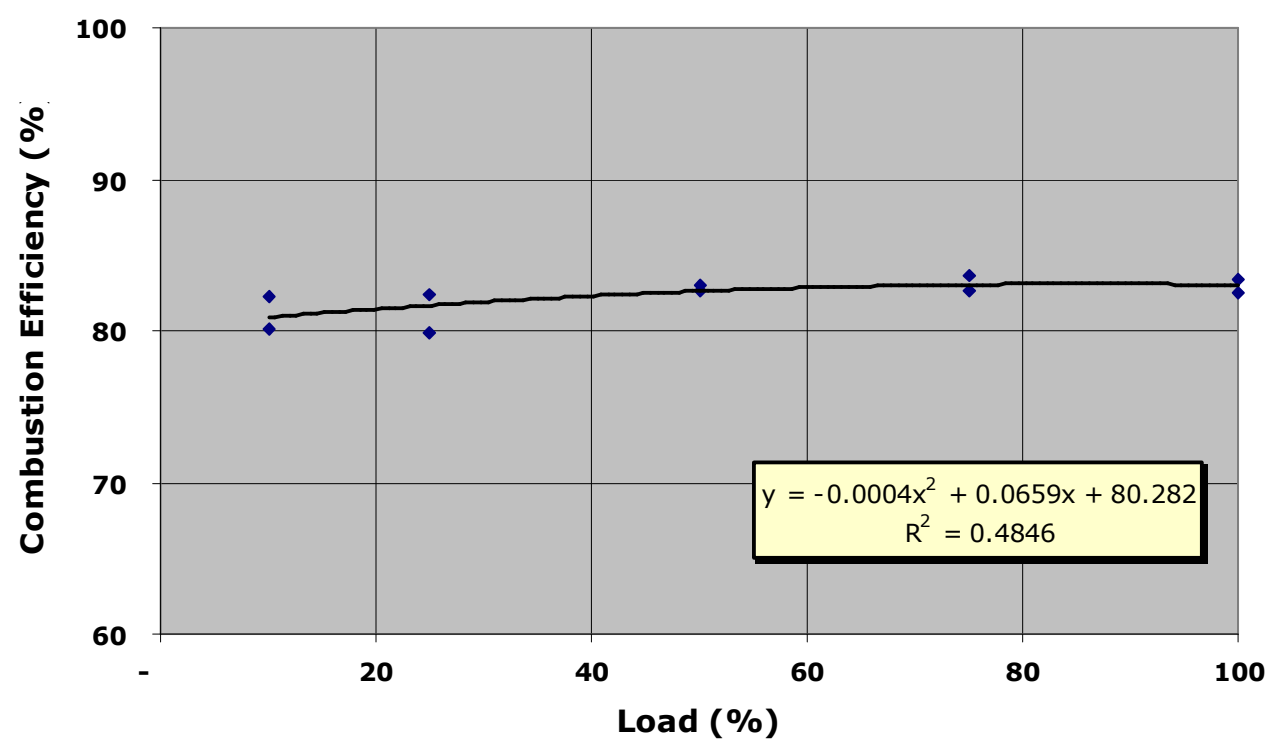

Figure A1b: Boiler 2 (1,500 hp) combustion efficiency

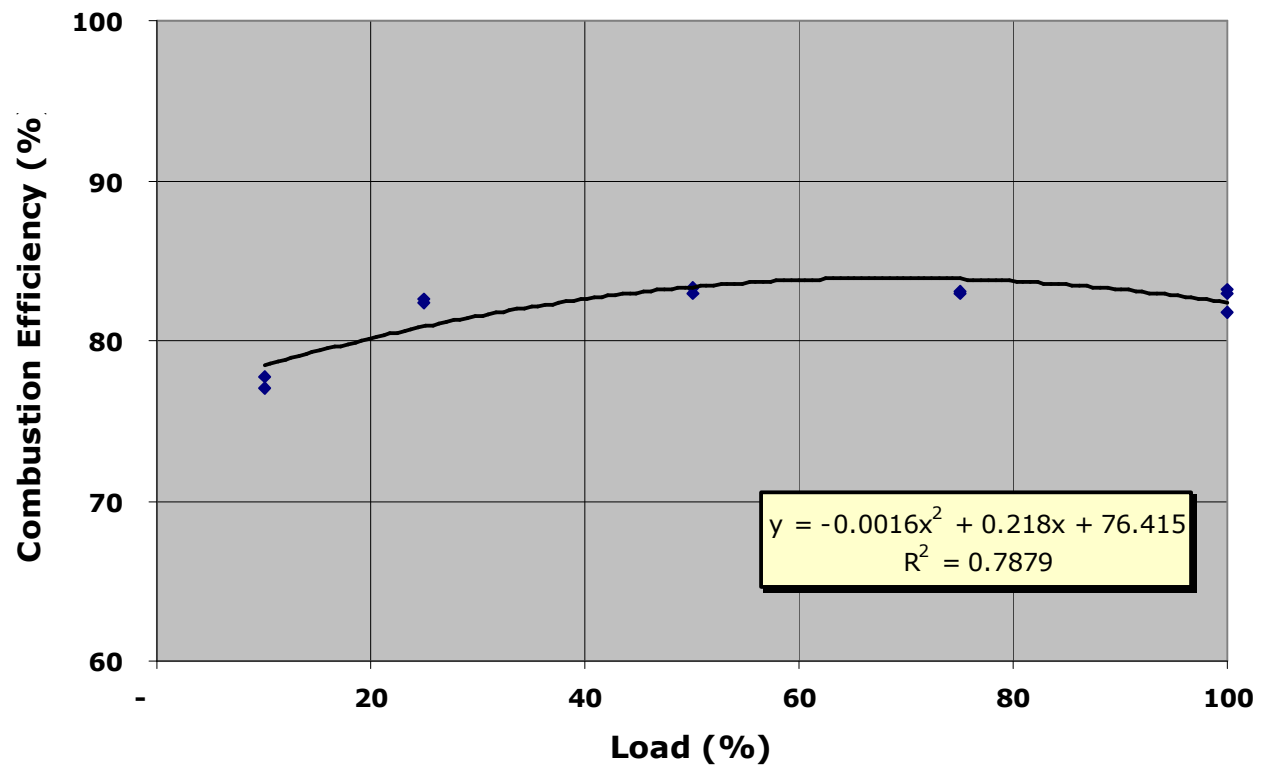

Figure A1c: Boiler 3 (1,200 hp) combustion efficiency 


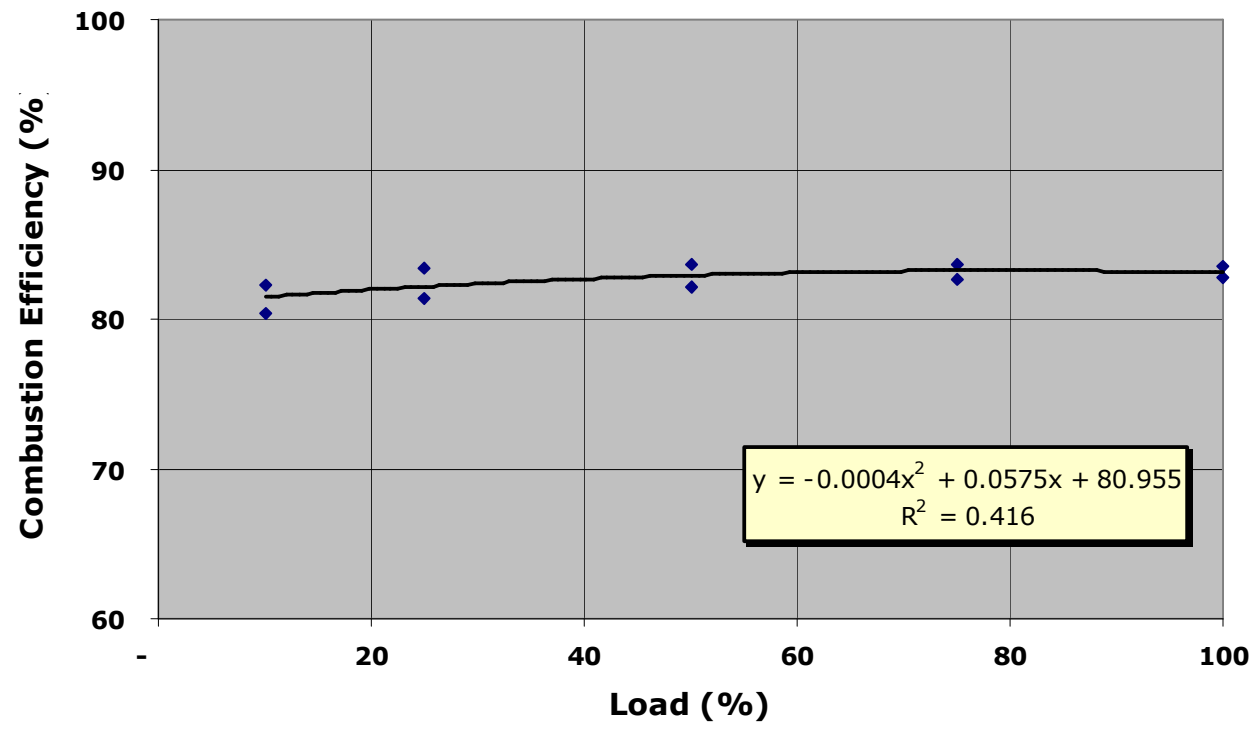

Figure A1d: Boiler 4 (1,200 hp) combustion efficiency 


\section{APPENDIX: IIC}

\section{NATURAL GAS COMBUSTION EFFICIENCY MODEL*}

\begin{tabular}{|c|c|c|c|c|c|c|c|c|c|c|c|c|c|c|c|}
\hline \multicolumn{16}{|c|}{ Natural Gas Stack Loss [\%] } \\
\hline Flue Gas & & & & & & & & & & & & & & & \\
\hline $\mathrm{O}_{2}$ Content & \multicolumn{15}{|c|}{ Flue Gas Temperature - Combustion Air Temperature $\left[{ }^{\circ} \mathbf{F}\right]$} \\
\hline$[\%]$ & 230 & 250 & 270 & 290 & 310 & 330 & 350 & 370 & 390 & 410 & 430 & 450 & 470 & 490 & 510 \\
\hline 1.0 & 14.7 & 15.1 & 15.5 & 16.0 & 16.4 & 16.9 & 17.3 & 17.7 & 18.2 & 18.6 & 19.1 & 19.5 & 20.0 & 20.4 & 20.9 \\
\hline 2.0 & \begin{tabular}{|l|}
14.9 \\
\end{tabular} & \begin{tabular}{|l|}
15.4 \\
\end{tabular} & 15.8 & 16.3 & 16.7 & 17.2 & 17.7 & 18.1 & 18.6 & 19.1 & 19.5 & 20.0 & 20.5 & 20.9 & 21.4 \\
\hline \begin{tabular}{|l|}
3.0 \\
\end{tabular} & 15.2 & \begin{tabular}{|l|}
15.7 \\
\end{tabular} & 16.1 & \begin{tabular}{|l}
16.6 \\
\end{tabular} & \begin{tabular}{|l|}
17.1 \\
\end{tabular} & 17.6 & 18.1 & \begin{tabular}{|l}
18.6 \\
\end{tabular} & \begin{tabular}{|l|}
19.1 \\
\end{tabular} & 19.5 & 20.0 & 20.5 & 21.0 & 21.5 & 22.0 \\
\hline \begin{tabular}{|l|}
4.0 \\
\end{tabular} & 15.5 & \begin{tabular}{|l|l}
16.0 \\
\end{tabular} & 16.5 & \begin{tabular}{|l}
17.0 \\
\end{tabular} & 17.5 & \begin{tabular}{|l}
18.0 \\
\end{tabular} & 18.5 & \begin{tabular}{|l|}
19.1 \\
\end{tabular} & 19.6 & 20.1 & 20.6 & 21.1 & 21.6 & 22.2 & 22.7 \\
\hline 5.0 & \begin{tabular}{|l}
15.8 \\
\end{tabular} & \begin{tabular}{|l|l}
16.3 \\
\end{tabular} & \begin{tabular}{|l|}
16.9 \\
\end{tabular} & \begin{tabular}{|l|l|}
17.4 \\
\end{tabular} & \begin{tabular}{|l|l}
18.0 \\
\end{tabular} & 18.5 & \begin{tabular}{|l|}
19.1 \\
\end{tabular} & \begin{tabular}{|l|l}
19.6 \\
\end{tabular} & 20.1 & 20.7 & 21.2 & 21.8 & 22.3 & 22.9 & 23.4 \\
\hline \begin{tabular}{|l}
6.0 \\
\end{tabular} & 16.2 & 16.8 & 17.3 & 17.9 & 18.5 & \begin{tabular}{|l|}
19.1 \\
\end{tabular} & 19.6 & 20.2 & 20.8 & 21.4 & 22.0 & 22.5 & 23.1 & 23.7 & 24.3 \\
\hline 7.0 & 16.6 & \begin{tabular}{|l|l}
17.2 \\
\end{tabular} & 17.8 & 18.5 & \begin{tabular}{|l|}
19.1 \\
\end{tabular} & 19.7 & 20.3 & 20.9 & 21.5 & 22.2 & 22.8 & 23.4 & 24.0 & 24.6 & 25.3 \\
\hline \begin{tabular}{|l|}
8.0 \\
\end{tabular} & 17.1 & 17.8 & 18.4 & \begin{tabular}{|l}
19.1 \\
\end{tabular} & \begin{tabular}{|l|l}
19.7 \\
\end{tabular} & 20.4 & 21.1 & 21.7 & 22.4 & 23.1 & 23.7 & 24.4 & 25.1 & 25.7 & 26.4 \\
\hline 9.0 & 17.7 & \begin{tabular}{|l|}
18.4 \\
\end{tabular} & 19.1 & \begin{tabular}{|l}
19.8 \\
\end{tabular} & 20.5 & 21.2 & 22.0 & 22.7 & 23.4 & 24.1 & 24.8 & 25.6 & 26.3 & 27.0 & 27.7 \\
\hline \begin{tabular}{|l|l}
10.0 \\
\end{tabular} & 18.4 & 19.2 & \begin{tabular}{|l|}
19.9 \\
\end{tabular} & 20.7 & 21.5 & 22.2 & 23.0 & 23.8 & 24.6 & 25.4 & 26.1 & 26.9 & 27.7 & 28.5 & 29.3 \\
\hline \begin{tabular}{|l|}
11.0 \\
\end{tabular} & \begin{tabular}{|l|l}
19.2 \\
\end{tabular} & 20.1 & 20.9 & 21.7 & 22.6 & 23.4 & 24.3 & 25.1 & 26.0 & 26.9 & 27.7 & 28.6 & 29.4 & 30.3 & 31.2 \\
\hline Flue Gas $\mathbf{T}\left[{ }^{\circ} \mathbf{F}\right]$ & 300 & 320 & 340 & 360 & 380 & 400 & 420 & 440 & 460 & 480 & 500 & 520 & 540 & 560 & 580 \\
\hline Ambient $\mathbf{T}\left[{ }^{\circ} \mathbf{F}\right]$ & 70 & 70 & 70 & 70 & 70 & 70 & 70 & 70 & 70 & 70 & 70 & 70 & 70 & 70 & 70 \\
\hline
\end{tabular}

* Model results available in US DOE SSAT and are provided by:

Greg Harrell, Ph.D., P.E.

Energy Management Services

1144 Hicks Road

Jefferson City, TN 37760

Telephone: (865) 7190173

Fax: (865) 4716098

Email: harrellg@utk.edu 
Hudson Technologies

MIddletown Road, Pearl RIver, NY 10965 


\section{APPENDIX: IID}

THERMOSORBER “WATT POULTRY USA” ARTICLE 


\title{
Energy-Saving Heat Pump Produces Sactding

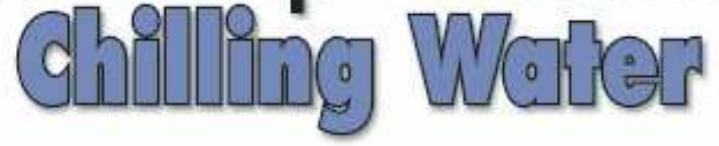

\author{
The Thermosorber can produce hot water at $140 \mathrm{~F}$ and cold water at $35 \mathrm{~F}$, closely matching the scalding \\ and chilling temperatures at poultry plants. \\ BY JATAL D. MANNAPPERUMA
}

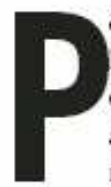

oultry processing plants require a continuous supply of hot water for scalding of birds and a continuous supply of cold water for chilling. Gas-fired water heaters or boilers are used to supply hot water, while electrically driven refrigeration systems are used to provide cold water. The cost of energy consumed by these devices is a major concern of poultry processors.

Heat pumps are devices that pump heat from a lower temperature to a higher temperature. In effect, they produce cooling and heating at the same time. Electrically driven heat pumps are popular in heating and air conditioning applications. Only heating or cooling effect is used at a given time, however, because the temperature lift is not adequate for both effects to be useful. Electrically driven heat pumps have an inherent disadvantage as heating devices when competing with inexpensive burners using cheep primary fuels.

Thermosorber is an improved heat pump developed by Energy Concepts Company in Annapolis, Md., with funding support from the U.S. Department of Energy. It is driven by thermal energy and is capable of producing high temperatures required in commercial water heating, while co-producing substantial cooling effect. It can produce hot water at $140 \mathrm{~F}$ and cold water at $35 \mathrm{~F}$, closely matching the scalding and chilling temperatures at poultry plants.

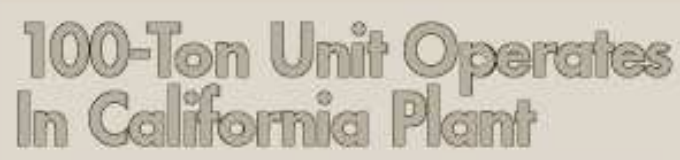

A 100-ton Thermosorber installed at a poultry processing plant in California's Central Valley in January 2006 prechills 110 gallons per minute of $70 \mathrm{~F}$ city water to $50 \mathrm{~F}$, en route to the continuous bath chiller. It also preheats 120 gallons per minute of city water to $120 \mathrm{~F}$, enroute to the continuous scalder. The unit is powered by $75 \mathrm{psig}$ steam.

The chilled water and the heat-pumped hot water are both produced from a single, natural gas heat source. Applying the natural gas heat to an ammonia water absorption cycle to produce both chilling and heating means twice as much benefit is derived.
Thermosorber operates on the ammonia absorption cycle. A solution of ammonia in water is pumped to a high pressure and

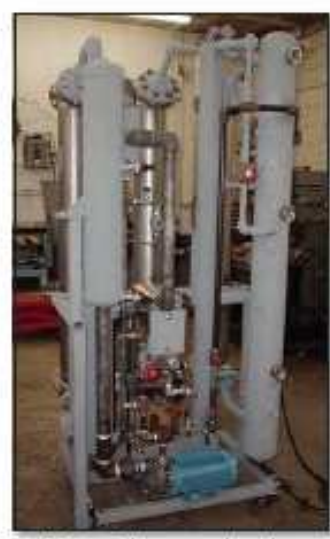

A 10-ton Thermosorber has a fooprint of only 3 feet by 3 feet. heated to generate ammonia gas. The gas is condensed and expanded to low pressure to produce cooling effect. Ammonia gas is absorbed to produce the low-pressure solution, and the cycle is repeated. The heat rejected in the condenser and the absorber provides the heating effect.

This cycle has the potential to produce 60 units of cooling and 160 units of heating for every 100 units of heat input. The electrical energy input is quite small compared to compressor-based refrigeration cycles. The Thermosorber based on this cycle has the potential to produce the same heating and cooling effects using 33 percent less thermal energy and 80 percent less electrical energy compared to conventional technology (see energy balances in the box).

The Thermosorber operates 21 hours per day, five days a week. It is designed to cycle on and off automatically, whenever there is a demand for both chill water and hot water, as indicated by level switches in respective storage tanks.

The installed cost of the system was less than $\$ 200,000$. Pacific Gas \& Electric provided an incentive payment for a portion of the cost, proportionate to the savings in natural gas. At design conditions and the prevailing Central Valley utility rates, the projected annual utility savings are $\$ 130,000$.

At the design rating of 100 tons, the Thermosorber supplies 3.2 million BTU/hour water heating and 100 tons of cold water chilling, from a steam input of 2 million BTU/hour. The installation achieves 100 -ton capacity when the city water pressure is high. The water pressure is usually restricted during plant operation, and the overall average capacity has been 92 tons.

\section{I WATT POULTRY USA I December 2006}


When both heating and cooling effects are fully utilized, this appliance has what is arguably the highest prime energy efficiency of any equivalent appliance. The projected payback in a typical application is about two years. (See figure.)

California Energy Commission sponsored the installation of a 10-ton Thermosorber at Squab Producers of California's processing plant in Modesto, Calif., to demonstrate the energy saving potential of the technology in poultry processing plants. Thermosorber provides base hot water for scalding and cold water for chilling. It is not possible to have complete control of flow rates and temperatures of both hot water and cold water due to interdependencies. Therefore,

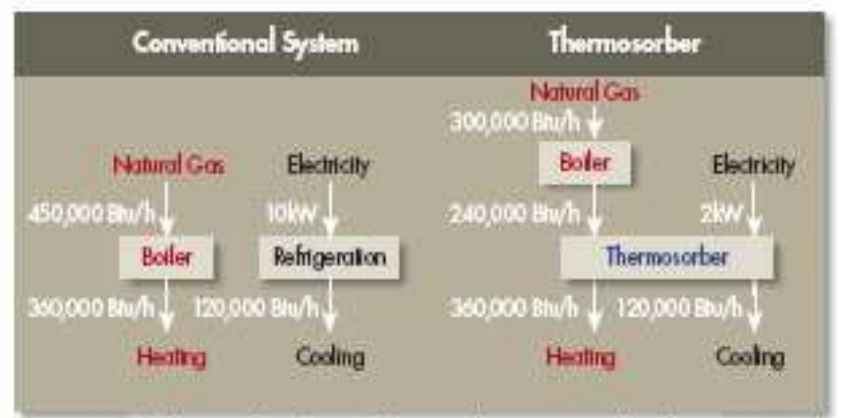

The energy balance of a 10 ton Thermosorber compared with conventional system supplying identioal heating and cooling loods.

the temperature control in the scalder is done by steam injection and in the chiller with ice addition. Hot water and cold water provided by the Ther mosorber replace city water at ambient temperature and produce substantial utility savings. The monitored performance of this installation over a six-month period indicated 68.3 percent savings in electricity and 27.7 percent savings in thermal energy compared to conventional technology.

The successful demonstration of the 10-ton unit was followed by the installation of a 100 -ton unit at a large poultry processing plant in

California. Increasing energy costs should encourage poultry processors to evaluate the potential use of this technology.

Jatal D. Mannap penma, Ph. D. foodeng ineering specialisț University of Califomia at Davis; Phone (530) 758-3708; Email jamarnappenuma Qucdavisedv 
(e) PACE

ATTACHMENT III

ROCKY RESEARCH, INC FINAL REPORT 


\section{Pilgrims Pride Corporation}

On-site Assessment of the Refrigeration Plants at Pilgrim's Pride Foods in Mt. Pleasant, Texas

November 28-30, 2006

Prepared by:

Rocky Research

Boulder City, Nevada 


\section{Table of Contents}

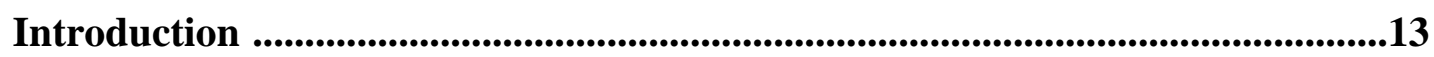

\section{Summary of Recommendations}

West Plant ......................................................... 13

East Plant......................................................... 15

Process Foods...................................................... 15

All Plants..................................................... 16

\section{Discussion of Recommendations}

West Plant........................................................ 17

East Plant......................................................... 17

Process Foods......................................................... 25

All Plants.............................................................. 30

Conclusions..................................................................... 31

Appendices

A. West plant load analysis....................................... 33

B. Energy values used in analysis.................................. 33

C. Engine driven chiller analysis................................... 34 


\section{Introduction}

The purpose of this effort was to perform a preliminary analysis of the potential for improved energy efficiency at the Mount Pleasant Pilgrim's Pride Facility Refrigeration Plants. The primary focus was on the East and West plants, but some observations were also made at the Process Foods Plant and these are included where appropriate.

The assessment took place over a 3 day period. The first day and a half were spent touring facilities and observing production floor operations. The last day and a half were spent acquiring/reviewing drawings and interviewing refrigeration plant operations personnel. Due to the limited amount of time available in this project, many of the recommendations presented require more in depth study to firmly establish baseline energy use, predict potential energy savings and acquire accurate implementation costs.

\section{Summary of Recommendations}

The following summarizes the recommendations for improved energy utilization derived from the refrigeration plants' assessment. Some items are simply changes in procedures with very little or no associated implementation costs. Some of the recommendations support changes already considered by operations personnel at least to some degree. Other recommendations will require new capital expenditures and should be thoroughly investigated technically and economically before implementation.

A conceptual design and installation bid by local contractors (or an internal cost estimating branch) is usually the most accurate way to justify the economics of a project. "Guestimation" of project implementation costs carries a high level of risk and should not be used as the sole basis for an investment decision. Accurate savings predictions for some of the recommendations require a more in depth study of the refrigeration plant operating conditions and load profile at each of the plants throughout a typical year. A one time spot check of loads is only of limited value. None of the necessary refrigeration equipment's electrical load data were available for analysis in this report since there is no electrical sub-metering in place for the major refrigeration equipment.

\section{West Plant}

1. Turn off process cooler rooms' evaporators during the wash-down shift to avoid the subsequent defrost load on the compressors.

2. Separate the ice makers from the rest of the house system and tie them to (existing) dedicated compressors and condensers so that the balance of the system head pressure can be allowed to float down when possible

3. Convert SC3 compressor to thermosiphon oil cooling (10-15\% operating savings) and change the liquid injection valve on SC5. 
4. Add a condenser to bring down summer head pressure for house system

5. Add microprocessor control to condenser fans. Do not cycle condenser water for capacity control (this can lead to increased scale buildup)

6. Look at options to separate cooler space from production space to lessen the refrigeration load in coolers

7. Balance air systems to minimize humidity in refrigerated zones

8. Place administration controls on King Air unit to prevent its being shut-off and creating the subsequent negative building pressure which draws in large amounts of outdoor air infiltration

9. Place evaporators' liquid solenoids/fans on automatic space temperature controls so the space is not overcooled. Tie these controls back into the computer system in the operations office

10. Install autopurgers at the condensers for control of non-condensable gases (head pressure reduction)

11. Timing for chilling water for bird chillers (460 $\mathrm{T}$ load) should be optimized based on electric billing structure

12. Investigate "cool" recovery from used bird chiller water.

13. Consider computer based monitoring/control/data logging system for the entire refrigeration system

14. Increase electrical metering to be able to monitor the refrigeration system performance (before and after energy measures are implemented)

15. Experiment with slowly raising suction pressure (after compressor sub-metering is in place)

16. Economics for the use of absorption chillers fired off waste heat should be examined if/when additional refrigeration capacity is anticipated. Refrigeration COP with waste heat should be expected to be low (at or below 50\% energy conversion efficiency).

17. It is not recommended to convert or add additional refrigeration capacity in the form of natural gas engine driven refrigeration equipment. 


\section{East Plant}

1. Install a computer control/monitoring system to incorporate the existing energy efficient manual operating strategies into automatic control. (Note: this may require hiring of personnel trained in the use/maintenance of such a computer system)

2. Investigate the use of variable speed drive control for the EC-1 and EC-2 condenser fans

3. Investigate lowering of condensing head pressure

4. Loading docks need better sealing at the truck bumpers

5. Replace ice makers with more efficient units (existing units require higher than usual head pressure and valves leak refrigerant)

6. Install autopurgers on ice system

\section{Process Foods}

1. Balance air systems to control infiltration

2. Investigate low side refrigerant line sizing to insure bottlenecks or high pressure drops are not causing the suction pressures to be unreasonably low for good performance at the evaporators.

3. Vary the amount of liquid fed to blast freezers to meet load

4. Investigate use of floating head pressure (the two following recommendations are directly related to this:

- Investigate thermosiphon design and performance (current barrier to lowering head pressure).

- Investigate scraped heat exchangers ability to be supplied with pumped liquid instead of high pressure liquid from the HPR (this may also be a barrier to lowering head pressure)

5. Review all fan coils' defrost timing for optimization

6. Repair/replace piping insulation on the roof piping

7. Investigate purge of production area air during/after wash-down

8. Investigate pumping liquid from medium temp receiver to LL receiver instead of from the high side receiver 


\section{Pet Foods Plant}

Not reviewed

\section{All Plants}

1. Update refrigeration system drawings to reflect current "as built" conditions

2. Meter the refrigeration systems so that performance can be monitored

3. Alter compressor sequencing if necessary to avoid running any screw compressor below about $65 \%$ capacity.

Table 1. Selected Measure Savings and Cost Estimates

\begin{tabular}{|c|c|c|c|c|c|c|c|}
\hline \multirow[b]{2}{*}{ PLANT } & \multirow[b]{2}{*}{ ECM } & \multirow[b]{2}{*}{ Description } & \multicolumn{3}{|c|}{ Annual Savings } & \multirow{2}{*}{$\begin{array}{l}\text { Cost } \\
\$ K\end{array}$} & \multirow{2}{*}{$\begin{array}{r}\text { Payback } \\
\text { (Years) }\end{array}$} \\
\hline & & & $\$ \mathrm{~K}$ & $\mathrm{kWh}$ & $\begin{array}{l}\text { Peak } \\
\mathrm{kW}\end{array}$ & & \\
\hline \multirow[t]{4}{*}{ West } & 1 & $\begin{array}{l}\text { Shutdown cooler evaporators } \\
\text { during washdown }\end{array}$ & 14.17 & 295,880 & & No cost & Immed. \\
\hline & 5 & $\begin{array}{l}\text { Add microprocessor controls to } \\
\text { condenser fans }\end{array}$ & 15.27 & 318,733 & & 20 & 1.31 \\
\hline & $6,7,8$ & $\begin{array}{l}\text { Air balance and reduce } \\
\text { interior/exterior infiltration }\end{array}$ & 4.97 & 103,740 & 21 & 10 & 2.01 \\
\hline & 12 & $\begin{array}{l}\text { Recovery of cooling energy from } \\
\text { waste water }\end{array}$ & 11.21 & 234,000 & 450 & 30 & 2.68 \\
\hline East & 2 & $\begin{array}{l}\text { Variable speed drives for condenser } \\
\text { fans EC- } 1 \text { and } 2\end{array}$ & 1.83 & 38,236 & & 8 & 4.36 \\
\hline & 6 & Install autopurgers on ice systems & $8.38^{1}$ & 109,832 & 10 & 17 & 2.03 \\
\hline $\mathrm{PF}$ & 4 & Use floating head pressure control & 75 & $1,202,240$ & 289 & 117- 297 & $1.6-4$ \\
\hline
\end{tabular}

Notes:

1. includes $2 \mathrm{hrs} /$ week labor savings 


\section{Discussion of recommendations}

The abbreviations (LC, MC and $\mathrm{HC}$ ) directly following the recommendation refer to estimated implementation costs (low, medium and high) using information that was available to date. A further discussion of these ratings can be found in the Conclusions section.

\section{West Plant}

1. Turn off process cooler rooms when in wash-down to avoid the subsequent defrost load on compressors. (LC)

The evaporators in cooler rooms are left running during wash-down operations. The high humidity results in coils frosting up in these spaces. Thicker than normal frost requires longer defrost periods, or if this is not done, heat transfer will suffer until the frost is eventually removed after a number of normal defrost cycles. Either way, the load on the compressors is increased.

Turning off the evaporators also saves fan energy. Some experimentation will be needed to establish the best time to re-activate the evaporators to insure the spaces are brought to the correct temperature before production starts.

2. Separate the ice makers from the rest of the house system and tie them to dedicated compressors and condensers so that the balance of the system head pressure can be allowed to float down when possible (MC)

One fact that currently prevents lowering the high side pressure for the house system is that the high pressure is needed for rapid and effective defrost of the ice makers. It appears feasible at this stage of system review that the ice systems could be separated from the general plant system thereby allowing the general plant pressure to be lowered while maintaining the higher pressure in an isolated portion of the plant strictly for icemaker defrost. Piping and valving would be needed to isolate compressors RC-1, 2 and 3 for icemaker duty (while still allowing them to be opened to the house system in an emergency). In addition, condensers 2 and 6 would then be valved and piped for icemaker duty. EC-6 is the closer choice, with EC-2 as a backup. This equipment also should still be accessible to the rest of the system in an emergency.

Assuming there are no other barriers found to separating the ice systems from the rest of the general refrigeration plant, a detailed study would then need to be done to establish the best condensing pressure for control of the rest of the system. The issue here is that during certain operating conditions, lowering head pressure decreases compressor power requirements, but it may actually increase condenser fan motor power requirements because fans must run more to bring head pressure down. There is an optimum condensing pressure for any given outdoor condition (wet bulb temperature). Since it is so dependent on ambient conditions, there is not a single optimum condensing pressure that can be recommended for this or any other plant. 
Savings from this operational modification can be significant. A rule of thumb is that compressor energy will be reduced by about $1 \%$ for every 2 psi reduction in head pressure (or approximately $1.3 \%$ reduction for each degree $\mathrm{F}$ of saturated condensing temperature). Assuming the load profiles for the West plant compressors as shown in Appendix A, and that an average of 9 degrees $\mathrm{F}$ reduction in condenser pressure can be realized on average year round, savings on the order of $\$ 38,500 / \mathrm{yr}$ in energy and demand charge costs are possible.

3. Convert SC3 compressor to thermosiphon oil cooling or change liquid injection valves on SC3 and SC5 (convert them to InteliSOC valves or equivalent). (MC)

This recommendation is in conjunction with recommendation \#2. After isolating icemaker operation, there is still a barrier to the lowering of head pressure in the West plant. It is the fact that out of all the screw compressors there are only two liquid injected compressors (method used for oil cooling). Typically, the injection valves on these compressors require a high upstream pressure in order to function properly. This can defeat the operator who would like to lower the high side pressure for energy savings. One solution is to retrofit these liquid injected compressors with thermosiphon oil cooling systems, which can result in 10-15\% savings versus their current operating method. SC5 is probably too far away to make a tie into the existing thermosiphon loops, but SC3 should be investigated for a thermosiphon retrofit. It can be expensive and the economics should be evaluated once a bid is obtained. A better solution may be to investigate the replacement of the liquid injection valves on SC3 and SC5 with improved valve trains that use an electronic valve for liquid injection. FES Systems makes the IntelliSOC system for addressing this issue. It allows head pressures to be dropped as low as 100 psi without problems arising with the liquid injectors or oil cooling capacity. A computer chip would also have to be replaced in the compressor control boxes to communicate with the new valve. This option is cheaper than retrofitting for thermosiphon oil cooling, but savings versus current method of operation are not as significant (since it still uses liquid injection). Mycom also makes an electronic liquid injection valve under the name of Yosaku that should be retrofittable onto SC5.

While the IntelliSOC (or Yosaku) system still uses liquid injection, which is not the most efficient way to cool compressor oil, it will allow the whole systems head pressure to be reduced which will have significant energy savings ramifications as shown above.

Any high side pressure reduction must specifically address the volume ratio of screw compressors involved. If the screw compressors are fixed volume ratio machines, an in depth review of the effects of shifting the compression ratio of the high stage compressors must be undertaken. Reduction of head pressure can actually result in higher energy consumption on the wrong fixed ratio compressor. If compressors are all variable ratio this should not be an issue.

4. Add a condenser to bring down summer head pressure for house system (MC)

Though not experienced during the late fall timeframe of this assessment, operations personnel report that head pressure rises significantly in summer months, (well above the typical 150 psi 
settings for condenser controls). This is an indicator that condenser capacity may be insufficient (or there are operational inefficiencies with existing condensers). It should be verified that excessive scaling, low water flow or inoperable fans or some other obvious cause for reduced condenser capacity doesn't exist. Otherwise, additional condenser capacity should be pursued. A detailed investigation should review current and anticipated future refrigeration loads before making this purchase. Note that strategies to lower high side pressure will only be partly effective if there isn't adequate condenser capacity available.

5. Add microprocessor control to condenser fans. Do not cycle condenser water for capacity control (this can lead to increased scale buildup). (LC)

Manual control of the condensers should be automated as a minimum. A stand alone microprocessor based condenser control system could be added at a relatively modest cost. Other energy reduction strategies such as variable speed drive retrofits for the fan motors can only be investigated once adequate condenser capacity is installed (see rec.4) and refrigeration load profiling for the plant is understood (using sub-metering for instance, see rec. 14).

A microprocessor based control system for the condenser fans would help insure head pressure is not higher than it needs to be. For instance, head pressure was running at 165 psi when we were present on a cold day, and we manually adjusted it down to $150 \mathrm{psi}$. This is why the operation should be automated. In addition, it can help the system operate more smoothly during load changes. The existing controls are not located in the operations office, hence they tend to be neglected until a problem exists. In addition, it was noted that there was some tendency to turn water pumps on and off for capacity control of the condensers. This practice should be avoided. Aside from additional wear on the pumps, this practice will lead to increased scaling on the condenser tubes as they are wetted and dried continuously.

Savings from automating fan control are hard to predict without knowing how much time the head pressure under manual control is higher than it has to be.

6. Look at options to separate cooler space from production space to lessen the refrigeration load in cooler \#1 specifically (LC)

There are large passages between conditioned cooler spaces and production areas. This places unnecessary loads on the coolers, both latent and sensible in nature. Strip doors or other products should be used in these interface areas to separate the zones more definitively. Where product goes through wall openings, the openings should be minimized and closed when not in use.

7. Balance air systems to minimize humidity in refrigerated zones.(LC)

The production areas are near $100 \%$ humidity. When this air is allowed to migrate into the coolers there is a huge latent load (and subsequent defrost load) placed on the compressors. It 
can largely be eliminated with proper air balance to insure flow of air between zones is minimized and where it does exist, airflow direction is optimized for energy efficiency.

8. Place administration controls on King Air unit to prevent its being shut-off and creating the subsequent negative building pressure which draws in large amounts of outdoor air infiltration. (LC)

This recommendation is similar to Rec.7 in that it addresses improper air balance that occurs when large pieces of air moving equipment are inadvertently shut off by plant personnel. If supply air systems are shutdown (for whatever reason), the exhaust systems should be shutdown as well to avoid situations where moist, hot outdoor air is drawn into cooler zones and other conditioned spaces.

9. Place evaporators' liquid solenoids/fans on automatic space temperature controls so the space is not overcooled. Tie these controls back into the computer control system (MC)

Controls for the coolers are inoperable. Fans run at full speed and solenoid valves are run wide open. Readouts indicate that these spaces are at times being overcooled which works compressors harder than necessary. It is important to reduce the refrigeration load in these spaces first (see recommendations $6,7,8$ ) then put zone thermostats in place as a minimum to modulate fans and valves to optimize energy efficiency. Once zone loads have been reduced, there should be no need to run the cooler units wide open as is now the case.

10. Install autopurgers at the condensers for control of non-condensable gases (head pressure reduction).(MC)

Non-condensable gases have an additive effect on system condenser pressure. The more noncondensables are present, the higher the system high side pressure and the harder the compressors have to work. Capacity is also reduced. Purging of these gases is presently done manually. But even a small amount of these gases cause compressors to work harder than necessary and they should therefore be purged regularly and often. Due to the shear number of condensers at the West Plant, all the purge points would require a fair amount of manual labor to keep them properly purged. An automatic purge system probably makes sense for this plant based on labor savings alone, but there are energy savings associated with this retrofit as well. The best place for purge points is on the top of the condenser drain legs above the liquid traps. This is assuming the traps are properly designed and don't blow through and are always full of liquid which essentially stops the flow of non-condensables further in the system.

11. Timing for chilling water for bird chillers (460 $\mathrm{T}$ load) should be optimized based on electric billing structure. (LC)

If electric rates are time of day dependent it would make sense to try to time the chilling of the water for the bird chillers so as to minimize energy charges. This load represents about 460 tons of cooling when it is put on line. 
The bird chiller systems were examined and, per request, the energy consequences of injecting hot air into the chillers for improved heat transfer were examined. It was found that the tonnage load on the chilling system from the hot air is minimal largely because the bubbles float to the surface and release their contents back into the room. In addition, empirical tests performed by operations personnel at the plant proved that when the hot air load is removed, chiller load does not change significantly. In addition, the manufacturer was contacted regarding this subject and he confirmed the other two conclusions, the blowers do not add a significant refrigerant load but significantly aid in the transfer of heat from the birds due to increased convective heat transfer in the tanks. The benefit should outweigh the energy cost.

\section{Investigate "cool" recovery from used bird chiller water. (LC)}

Used cold water is dumped to drain from the bird chillers at the end of shifts so the tanks can be cleaned. A full new batch of water must then be chilled down to $34 \mathrm{~F}$ so the tanks can be refilled. An investigation into the feasibility of exchanging heat from the tank refill (city) water headed for re-chillers to the water going to drain may yield a worthwhile project.

13. Consider computer based monitoring/control/data logging system for the entire refrigeration system (M-HC)

The plant is basically manually run and monitored. There are a number of benefits from investing in a computer system for monitoring, control and data logging.

- it saves labor since the health of the plant can be observed from a central location without having to tour the compressor rooms, coolers, etc

- Trends in operating variables can be plotted, such as cooler temperature, suction or discharge pressure, etc. The better operations personnel can understand what the system is doing and how it is reacting to loads, the better they will be able to optimize strategies to lower the overall energy consumption of the systems.

- Variables can be plotted against each other to determine key relationships related to energy saving strategies: how sensitive is refrigeration load to outside temperature? Can evaporator fans be turned off for significant periods of time without adversely affecting cooler operation? (possible in storage cooler for instance)

- The effect of small changes to operating variables and control strategies can be seen immediately making fine tuning of controls much easier

- Control of the condenser fans, cooler space temperatures, etc as recommended in this report could all be centralized into one operating system instead of the distributed control scheme now used. Outputs should be available from the existing individual compressor control panels that will have many of the key variables desired, eliminating the expense for redundant sensors and wiring.

- Safety and reliability are enhanced since off design operating conditions can be identified long before they turn into problems. 
As a minimum the following should be candidates for the data sensors where they don't already exist:

Pressure

Liquid leaving the condenser and high pressure receiver

Outlet of the evaporators

At all pressure regulating valves

Inlet and outlet of liquid recirculating pumps

Temperatures

Compressor suction and discharge

Liquid refrigerant leaving condenser or receiver

Refrigerant entering and/or leaving evaporators

Liquid leaving low pressure receiver (recirc)

For water chillers, the inlet and outlet water temperature and flow rate should be monitored

14. Increase electrical metering to be able to monitor the refrigeration system performance (before and after energy measures are implemented) (MC)

The lack of sub-metering at any useable level at the plant makes it very difficult to gage how the refrigeration plant is now operating in terms of efficiency or to establish a baseline of energy consumption patterns against which the effectiveness of all future energy savings measures can be evaluated. Without usage pattern details, it is also difficult to predict the savings potential of recommendations presented in this report.

Target areas for electrical metering of the refrigerant plant are the 3 major users of power: the compressors, the condenser fans and the evaporator fans. The power drawn by these groups should be kept separate, if at all possible, and should be further sub-metered on those pieces of equipment that do not run full time. Energy use of equipment that runs at full load all the time can be figured by point power measurements when under load and multiplied by hours of operation.

Real time electrical measurements can be used by operations personnel to see immediate effects of their control modifications on energy consumptions and can be a very useful tool in fine tuning a refrigeration plant for minimum energy consumption.

15. Experiment with slowly raising suction pressure (after compressor sub-metering put in place) (LC)

Reducing the pressure difference across the compressors saves energy. This can be done by lowering outlet (condenser) pressure, as already discussed or by raising suction pressure. 
Raising the suction pressure is generally only effective if there is excess heat transfer surface area available, or there is room for additional unit coolers (otherwise the load will not be met at higher evaporator temps). Net power savings need to pay for the additional surface area (usually in the form of additional cooler units for example).

It should be noted that as suction pressure is increased, fan energy can increase (if more evaporator units are put on-line), compressor energy can increase slightly (although compressors will operate more efficiently and at a higher capacity) and compressor life may be increased (less wear). For this facility, it appears as if there is very little excess evaporator surface since units are running at full capacity all the time and just meeting load. More evaporator capacity is likely needed in order to pursue this recommendation. A detailed study of loads, room for additional unit coolers and improved operating efficiency of the various compressors at higher suction pressures will define the economics and direction this recommendation should take.

Care should be taken in implementing this strategy such that compressor motors, oil separators and other system components are not overwhelmed if an increase in system capacity occurs. This will depend on how tightly the system piping and components were designed to originally envisioned system load.

Note: Compressor capacity increases about $2.5 \%$ per each degree rise in saturated suction temperature. Depending on the amount of rise, this may partially alleviate the need for a new compressor(s) in the future

16. Economics for use of absorptions chillers fired off waste heat should be examined if/when the need for additional refrigeration capacity is anticipated. (NA)

The immediate need for capacity increases was not mentioned during interviews so this option was not pursued in detail. Retrofit (replacement of functioning compressors) with absorption chillers will not make sense here. If waste heat is eventually targeted for use to run absorption chillers, operating COP will be low due to low firing temperature.

17. It is not recommended to convert or add additional refrigeration capacity in the form of engine driven refrigeration equipment.

At current gas costs and fairly low electric rates it doesn't make sense to use engines vs. conventional electric motor driven compressors. The economics could improve somewhat if waste heat could be used off such engines, but there is an excess of waste heat already at the plant. Unless there is a huge increase in gas rates (approaching $\$ .13 / \mathrm{kwh}$ ) natural gas engines should be avoided.

The above recommendations are based on the understanding from interviewing operations personnel that there are no direct expansion refrigeration loads in the West Plant. 


\section{East Plant}

1. Install a computer control/monitoring system to incorporate the existing energy efficient manual control operations. (Note: this may require hiring of personnel trained in use/maintenance of such a system) (M-HC)

The refrigeration plant operations team led by Mr. Terry Shelton was found to be doing an impressive job of operating this aging plant in the most energy efficient manner possible. He is well versed in the energy consequences of many of the operating controls and schemes available to the refrigeration plant operator and he implements everything that is possible in his plant, sometimes challenged by outdated and aging equipment. The potential problem is that everything at this plant is done manually under his direction. Personnel routinely "make the rounds" in the plant checking temperatures and pressures at various points around the systems and making real time choices about what adjustments to make for best operation.

This is all fine while T. Shelton is present, but his transfer was in progress during our visit and his exceptional knowledge of energy conservation strategies in operating this plant may or may not be lost over time. Accordingly, this plant could benefit in a number of ways by getting a plant wide monitoring/control system in place to automatically monitor and control equipment using energy conservation strategies.

Knowledge levels of existing plant personnel for using and maintaining the electronics and software required for this recommendation are unknown. It may be necessary to train existing or hire additional personnel versed in the use of these types of computer systems. (see recommendation \#13 for the West Plant for benefits of such a system)

2. Investigate the use of variable speed drive control for the EC-1 and EC-2 condenser fans (MC)

Based on the discussions with the operators, the refrigeration load pattern at this plant is conducive for retrofit of the condenser fans with variable speed drives. More data needs to be gathered to establish the actual use pattern of the condenser fans on a year round basis in order to determine potential energy savings from this retrofit.

\section{Investigate lowering of head pressure (potentially LC)}

There appears to be more condenser capacity available than load at any given time on the house (non-ice) system. The ice system is completely separate from the house system. The one screw compressor uses a thermosiphon oil cooler instead of liquid injection. Assuming there are no direct expansion evaporators or other barriers where high pressure liquid is required for feeding low pressure loads, using floating head pressure control appears to make sense for this part of the plant. It can be especially effective if recommendation 2 is pursued as controls will be able to maintain constant lowered pressures to maximize savings 


\section{Loading docks need better sealing at the truck bumpers (LC)}

This recommendation was a suggestion by one of the operators who notices leakage into and out of the refrigerated dock area due to poor seals around the incoming truck trailers parked against the bumpers on the building. Infiltration can be a major load on the coolers' evaporators and remedies to stop this type of load are very likely cost effective.

5. Replace ice makers with more efficient units. (M-HC)

The ice system is old. From compressors to ice makers to condensers, the whole system should probably be inspected in detail for potential replacements and upgrades. In particular, the icemakers should probably be replaced. New units will undoubtedly be more efficient. The existing units require higher than normal head pressure and valves leak refrigerant. The higher head pressure forces the compressors to work harder than necessary.

The investment cost for new equipment cannot be paid for by energy savings alone, but the energy inefficiency of the existing units should certainly be added into the equipment replacement equation (along with maintenance costs) when deciding when to retire worn out capital equipment.

\section{Install auto purgers on ice system (MC)}

Non-condensable gases have an additive effect on system condenser pressure. The more noncondensables are present, the higher the system high side pressure and the harder the compressors have to work. Capacity is also reduced. Purging of these gases is presently done manually. But even a small amount of these gases cause compressors to work harder than necessary and they should therefore be purged regularly. An automatic purge system probably makes sense for this plant based on labor savings alone, but there are energy savings associated with this retrofit as well. The best place for purge points is on the top of the condenser drain legs above the liquid traps. This is assuming the traps are properly designed and don't blow through and are always full of liquid which essentially stops the flow of non-condensables in the system.

\section{Process Foods}

Because there was no information given to Rocky Research about this plant prior to the site visit, time spent on site was primarily data gathering, locating drawings and interviewing of operations personnel. The refrigeration systems at this plant are large and loads are diversified making careful analysis of the picture as a whole important. Below are some specific recommendations derived from obtaining and briefly studying block refrigerant flow diagrams on site and also from interviews with plant operations personnel.

1. Balance air systems to control infiltration (L-MC) 
The production area is connected to the outdoors through a number of access routes. Personnel report large flows of air through these doorways and hallways. Infiltration can be the single largest part of the load on unit cooler evaporators trying to maintain temperature on the production floor. The best way to eliminate infiltration at doorways is weather stripping and vestibules or the use of strip doors in high traffic areas. But more importantly is to insure there are not large differential pressures between the outdoor and indoor spaces.

Balancing the amount of outdoor air brought into the space with that being exhausted through hoods and ovens, etc. is the key to air balancing. In the case of this space, the amount being exhausted varies depending on production load primarily due to oven operation and stacks associated with them. Since the situation is not constant a static air balance will do little to solve the problem. It is recommended that air balancing be accompanied with the installation of space pressure control to vary make-up air supply to the space as needed to match production load exhaust requirements.

A variable speed make-up air retrofit will be needed. Depending on the volumes of air involved after studying the various exhaust loads and their usage pattern, an air to air heat exchanger may be economical to reduce the cost of conditioning outdoor air. Design for condensate removal will be key. In addition, the system should be designed to meet minimum ventilation requirements when production exhaust is at a minimum.

2. Investigate low side refrigerant line sizing to insure high pressure drops or low velocities in risers are not causing the suction pressures to be dropped unreasonably low for good performance at the evaporators. (potentially M-HC depending on the exact problem detail)

This recommendation stems from discussions with refrigeration plant and other personnel regarding operating conditions at the plant. There are some mixed opinions about what the potential problem is. Some believe that the runs of refrigerant piping returning from the spiral freezers are poorly designed and that it may be better to collect and pump refrigerant liquid back to the recirculators than it would be to suck this liquid back with the compressors (which is how the system is described as working now). This presumes there is too much liquid being overfed to the evaporators.

Another opinion is that poor evaporator performance may be due to running the spirals at much higher loads than their design values and that pressure drops may be due to higher masses of gaseous refrigerant traveling through the piping than original design values.

The problem needs better definition. Pressure/temperature readings can reveal much of the story but none were received by the time of this writing. There also may be something else present which is not related to pressure drop from the suction header above the spirals back to the recirculator. There may be liquid holding up in the suction risers, because they may be too large. The velocity is not high enough to entrain liquid and carry it up the riser to the return header. The static liquid head on the coils then makes evaporator pressure higher than suction header pressure above the coils. This pressure penalty translates to higher evaporator temperature which then makes it necessary to run compressors at an even lower pressure to try 
to get the temperature down in the coils. In other words, compressor suction pressure is not lowered to overcome long piping pressure drop, but to overcome a static head problem at the coil.

It is really not certain what the issue is at this time and further investigation into real time operating data is definitely in order. Apparently there have been a number of individuals/consultants, etc. questioned on this subject without it ever really being resolved. If it is the result of overloading (should be easy to determine from manufacturers data vs. lbs of product going through equipment) there is really nothing that can be done short of equipment upgrade. If temperatures indicate there is superheating going on in the coils, then the coils are not receiving sufficient overfeed liquid and are definitely overloaded

On the other hand, if it is liquid back-up problem at the coils, (which may only occur at lower loads) ASHRAE's recommendation on how to deal with such cases is to either size dual risers for the return liquid legs (one larger than the other) to handle the variations in load and still have enough velocity to carry liquid back up to the header or to have a local separating vessel which would allow vapor to rise to the return header unrestricted while liquid gathered in the vessel would be pumped overhead back in to the return header as well. A careful review of load variations is needed to decide on the best strategy here.

3. Vary the amount of liquid fed to blast freezers to meet load (MC)

This is tied in with discussion of \#2 above. The amount of liquid overfeed (and hence return liquid volume) should be varied to meet load. There are reports of over freezing of product (which wastes energy). This occurs because the overfeed rate and operating set points are set for the worst case load and left there. At lower loads, recirculation pumping energy is higher than it should be and compressors have to work harder than necessary to maintain evaporator performance (see above).

Hand valves and a method to set the liquid flow rate to each coil during lower load periods should solve this problem. There is some anxiety that this poses a risk to production due to possible down time from changing valve settings, but if the adjustments are made slowly with a sharp eye on the operating parameters displayed through the computer monitoring system, the risk of upsetting the system should be minimal.

If hand valves are wide open and there is inadequate flow for full product load, the orifices built into the coils are probably limiting. The coil manufacturer should be contacted for the feasibility of increasing orifice sizes to increase coil capacity.

4. Investigate use of floating head pressure (the two following recommendations are directly related to this: (MC)

- Investigate thermosiphon design and performance (a current barrier to lowering head pressure). 
The thermosiphon system(s) for oil cooling in the screw compressors needs to be investigated in detail. Apparently attempts to lower head pressure have been attempted with negative results since oil cooling capacity cannot keep up with load and compressor oil heatup occurs. This is very likely to occur because of undersized thermosiphon lines (for this operating condition). Lowering head pressure means more ammonia mass moves through the thermosiphon system. This can lead to a gas bound system, if pipe sizes were not designed for the higher gas flow rate. A specific target area to look for undersized pipes is the equalizing line used to vent off the high pressure receivers.

Any high side pressure reduction must specifically address the volume ratio of screw compressors. If the screw compressors are fixed volume ratio machines, an in depth review of the effects of shifting the compression ratio of the high temperature compressors must be undertaken. Reduction of head pressure can actually result in higher energy consumption on the wrong fixed ratio compressor. If compressors are all variable volume ratio there should be no issue.

In addition, it needs to be investigated whether the thermosiphon load could be transferred to a separate (existing) condenser, if oil cooling continues to require higher head pressures to be maintained. This separation would then allow the rest of the system head pressure to float down with ambient and the majority of compressors could operate under lower head pressure. Lowering the head pressure(s) for this plant would result in large energy savings due to the shear number and sizes of affected compressors. It is probably the single most important strategy to pursue for this facility.

The exact loading pattern of the screw compressors needs to be investigated in detail, but it would be safe to assume that savings will be on the order $8 \%$, if head pressure can dropped by 16 psi or so. This amount (8\%) is a significant amount of energy considering there are over 8000 $\mathrm{hp}$ of compressors in place at this facility. A savings of $\$ 75,000 /$ year would not be unreasonable considering both energy and peak power charge reductions.

- Investigate scraped heat exchangers (HE-1,2) ability to be supplied with pumped liquid instead of HPL (since this may be a barrier to lowering head pressure as well).

More detail is needed on the installation of the scraped heat exchangers to see if they are being fed directly with high pressure liquid, which was indicated by one of the operators. If this is the case, lowering head pressure may affect supply of liquid to these heat exchangers. It would be better to supply these units with pumped liquid refrigerant from a recirculator, therefore allowing head pressure to be lowered with no adverse effects. If the units were designed for HPL, they can very likely be retrofitted to work with pumped liquid.

5. Review fan coil defrost timing for optimization (LC) 
There are some fairly long defrost cycles (20 minutes or more) being used on the unit coolers in the production area. These times need to be reviewed and some experimentation should be done to optimize the defrost operations since there are so many unit coolers at this plant.

As operated it may indeed take twenty minutes to defrost the coils, but it is usually better to have shorter on-line times and shorter defrost times because the average heat transfer from the coil is better. It should be verified that all coolers need this long a cycle.

Over-defrosting (to the point of steaming coils or worse yet dry coils) wastes compressor energy in two ways; by the use of more hot gas than necessary and by heating up the space and coils themselves which then become a subsequent load to the refrigeration system.

Data logging on the existing computer system can be beneficially used to monitor the effects of various defrost strategies until the most efficient sequence is developed.

6. Repair/replace piping insulation to the roof piping (LC)

Piping insulation for refrigerant lines on the roof need to be repaired and replaced in certain areas. Production personnel are aware of this need and there should be forthcoming projects to correct the situation.

7. Investigate purge of production area air during/after wash-down (L-MC)

The make-up and exhaust system requirements addressed in recommendation \#1 should also take into consideration the ability to flush the production area with outdoor air during and/or after the wash-down operation to remove the water vapor that eventually settles on unit cooler coils as ice which then must be removed by the hot gas system at the expense of increased compressor load.

Flushing the production area fairly rapidly with purge air from outdoors will keep from warming up the considerable mass of equipment, concrete and structure of the space so that it can be returned to production temperatures rapidly once the moisture is eliminated from the space. Removal of the steam from the space (and the defrost load on the coils) should far outweigh the energy cost of purging. It will be important to program different defrost cycles during the off shift so that savings are maximized.

8. Investigate pumping liquid from medium temp receiver to LL receiver instead of from the high side receiver. (L-MC)

This recommendation is primarily derived from studying the plant piping drawings, which may or may not represent true field conditions. Three recirculators are shown that are run at three different pressures. It appears that both the lower temperature receivers are fed from the one high temp recirculator. Depending on actual operating pressures, it may make sense to feed the lowest temp recirculator from the medium temp recirculator instead of the high temp recirculator. 
The effect of this is to move part of the flash gas load created when a higher pressure liquid feeds a lower pressure receiver to the medium temperature compressors instead of the low temp compressors. Ultimately, all makeup liquid must come from the high temperature recirculator, but if it feeds the low temp recirculator directly, all the flash gas becomes a load on low temp compressors, which are the most expensive to operate from an energy standpoint.

Instead, if liquid is fed from the high pressure recirculator to the medium temperature recirculator, then finally to the low temperature recirculator, part of the flash gas will occur at the intermediate pressure, eliminating this load from the low temp compressors.

This may be significant if : The 1600 tons from the spiral and blast freezers is at full load and in operation a significant portion of the time, the intermediate pressure is significantly different from the high or low pressure and it is desirable to get more capacity out of the low temperature (spiral/blast freezer) system.

This may not be a big a huge savings item (possible savings on the order of $\$ 5000 / y r$ ), but it may pay for itself depending on the complexity of the modification which needs to be investigated.

\section{Pet Foods}

No information was transmitted to Rocky Research about this refrigeration plant prior to or during the site visit that would allow us to do an energy use evaluation of this facility.

\section{All Plants}

\section{Update refrigeration system drawings to reflect current "as built" conditions (LC)}

It is very difficult for an outside firm to come in and evaluate a system and its performance if there are not good records and drawings of what equipment is installed and how the plant is operated (control systems details for instance). It is also difficult for operating personnel to do their best job when this key information is not at their fingertips. Drawings we were given were badly out of date in terms of how things were hooked up and even what equipment was present or functional. While all the operators we met obviously were well aware of what equipment was present and aware of how their plant functions, this information does not exist properly on paper making it very difficult to assess the situation for an outside firm or even for new employees. It also makes system trouble shooting more difficult than necessary.

It is strongly recommended that system block flow diagrams, at a very minimum, be updated (replaced) to reflect the current systems' configurations, including details of piping and valving of all equipment. Up to date control logic and sequence of operation documentation should be put in place for all equipment. 
2. Meter the refrigeration systems so that performance can be monitored (MC)

Ideally, separate metering of the compressors, condensers and evaporators would be installed to not only establish a baseline of energy use against which improvements can be measured, but also to monitor, track and strive to lower the energy costs over time. Turning energy into a visible commodity can go a long way in getting people involved in the quest for higher efficiency. If this degree of sub-metering is deemed too expensive, each refrigeration system as a whole should be metered. There are currently (6) of these on site and there would be (7) if recommendations are turned into projects at the West plant.

3. Alter compressor sequencing if necessary to avoid running any screw compressor below about $65 \%$ capacity. (LC)

Capacity control sequences were not reviewed for all plants in detail. With the numbers of screw compressors in use at this facility, it is worthwhile to examine the loading on all the screw compressors s to insure that they are not running under-loaded. Below about $65 \%$ load their efficiency drops off rapidly. If under-loaded screw compressors are identified, their loads can be shifted to reciprocating compressors or more properly distributed among other screw compressors to avoid the under-loaded situation.

4. Similar goals need to be established for refrigeration operations staff and production staff so that it is possible to establish an environment where refrigeration systems run reliably and at maximum capacity while maintaining an energy efficient plant.

There seems to be some fear that energy efficient operating strategies can lead to down time and production penalties. While the refrigeration staff may be very willing to pursue energy efficient strategies, necessary experimentation to optimize controls may be avoided because the cost of any downtime is considered too great. In short, production goals override energy efficiency improvements in some cases. This is typical and understandable. But it needs to be realized that with careful planning, design and implementation, it is possible for production capacity, system reliability and energy efficiency to co-exist.

NOTE: Due to a redistribution of the site assessment team's work load in an effort to complete a large amount of work in a short period of time, the responsibility of examining the refrigeration plant condensers was shifted to W.J. Turpish and Associates and their recommendations should be found in the main body of the Energy Assessment Report. Any recommendation to improve the efficiency of the condenser systems should be performed before following recommendations in this report regarding lowering of high side pressure or purchase of additional condenser capacity.

\section{Conclusions}

This report should be used as a tool for proceeding down a path towards improved energy efficiency in the refrigeration plants. It identifies the best places to look for energy saving 
projects and gives advice on how to proceed with conceptual designs of the recommended modifications. There are energy savings to be realized at this facility, some of them significant. But there are no project paybacks provided with this report for two reasons: there are no energy savings estimates and there are no project implementation costs. Energy saving predictions require a more in depth study of the annual load profiles on the refrigeration plants. This will be difficult with current systems, because they are for the most part not metered. A significant effort is required (when all plants are considered) to define or manually document refrigeration system load profiles. Due to the large number of compressors, and the different ages, makes and models involved, the changes in energy consumption derived from lowering head pressure (for an example of one conservation strategy) requires a study of the performance curves of all these compressors. This is beyond the scope of this preliminary audit.

Construction cost estimates should be derived from experienced cost estimators or from bids received to do the actual work. Guessing at implementation costs is generally inaccurate and sometimes misleading. Preliminary conceptual designs are needed as a minimum to begin to think about costs. Conceptual designs were not part of the scope of work for this project.

Simple payback numbers can be somewhat misleading at times, since they are really only good at any one plant and do not consider life-cycle costs. In addition energy charges and construction costs vary considerably by location. What makes sense at one plant location may not make sense at another. Caution should be used in implementing modifications to facilities across the board due to favorable economics at one plant location. In addition, refrigeration systems will vary considerably by location as all industrial ammonia systems do, and subtle differences can make or break the viability of some energy saving strategies.

Recommendations have a key code entered directly after them in parenthesis. It is our opinion that low cost (LC) recommendations should be implemented as soon as possible and will have rapid if not immediate payback. They don't really need a formal study to justify them, they should simply be done as good practice. Medium cost (MC) projects require further investigation to be justifiable, technically and economically, but there should be several good payback projects, in particular recommendations WP\#2 and PF\#4. High cost (HC) projects need to be looked at in depth, have a conceptual design developed and have professional cost estimating or contractor bids obtained to justify capital expenditures and insure ROI goals will be met.

If it is the future intent to track the improved energy performance for the refrigeration plants that are undertaking energy improvement projects, the first phase is to obtain baseline energy data for a long enough period of time and in enough detail so that changes in consumption can be measured. The facilities at Mt Pleasant, TX are currently not electrically sub-metered at a level sufficient for this type of baseline energy assessment of the refrigeration plants. 
Exhibit A. West Plant Estimates of running time and load for use in savings calculations

Winter Months approx.4 months

RC4 - N.A.

RC5 - N.A.

RC6 - 8hrs/day 2day/week full load

RC7 - 24hrs/day 7day/week full load

RC8 - 8A Mycom pump-out comp.

SC1 - seldom

SC2 - 18 hrs/day 5 days/week $80 \%$

SC3 - seldom

SC4 - N.A.

SC5 - 8hrs/day 5 days/week $80 \%$

SC6 - 18hrs/day 5 days/week $100 \%$

SC7 - 18hrs/day 5 days/week $100 \%$
Summer Months approx. 8 months

N.A.

seldom

16hrs/day 5 days/week full

24hrs/day 7 days/week full

N.A.

16hrs/day 5 days/week full

18hrs/day 5 days/week full

16hrs/day 5 days/week $75 \%$

N.A.

16hrs/day 5 days/week $75 \%$

18hrs/day 5 days/week $100 \%$

18hrs/day 5 days/week $100 \%$

Exhibit B - utility rates used in savings estimates

Electric $=\$ .0479 / \mathrm{kwh}$ and $\$ 5.01 / \mathrm{kw}-\mathrm{mo}$

Gas $=\$ .9374 /$ therm 


\section{(C) PACE}

\section{Exhibit C - Gas Engine Economics}

\section{Payback Calculator}

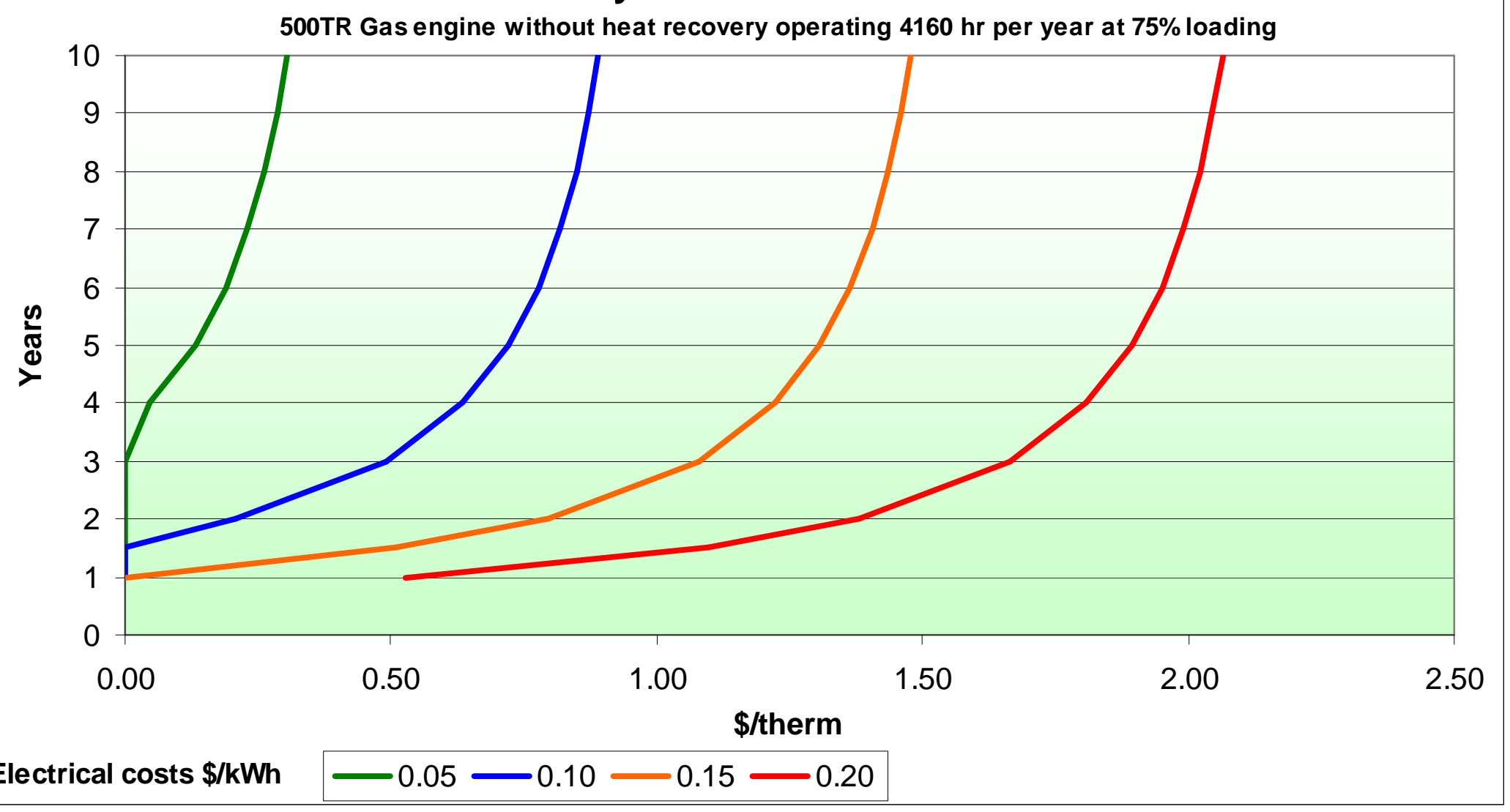


(e) PACE

W.J. TURPISH AND ASSOCIATES FINAL REPORT 


\title{
(e) PACE
}

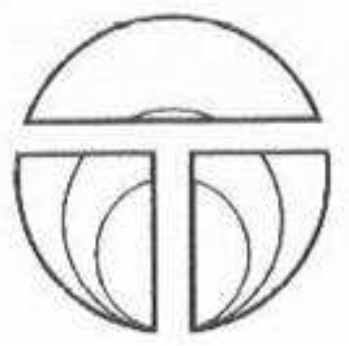

W.J. TURPISH AND ASSOCIATES

\author{
Process Cooling Assessment \\ Pilgrim's Pride Corporation \\ Pittsburg, TX \\ December, 2006
}

W.J. TURPISH AND ASSOCIATES, P.C.

439 Neisler Street * Shelby, North Carolina 28152

Telephone (704) 482-9444 - FAX (704) 482-9881 


\section{PROTEIN PLANT}

\section{General}

The protein plant processes byproducts from the East Plant, West Plant, and Prepared Foods on this site as well as byproducts from a number of additional plants which are delivered by truck to this facility.

The plant produces blood and feather meal, pet food (dry and wet), poultry food components, and oil.

Process cooling is required for heat exchangers and condensers in the rendering process.

\section{Cooling Tower System-Overview}

All the cooling is provided by a single cooling tower with five (5) cells. The original tower was constructed with two (2) cells prior to the acquisition of the facility by Pilgrim's Pride. An additional three (3) cells were added by BAC-Pritchard in 1986. All the cells are induced draft, cross flow units with $75 \mathrm{hp}$ fans.

Currently the tower is operating with four (4) of the fans. The remaining fan is locked out due to corrosion failure of the 'torque tube'. This is the structural support for the fan drive and motor. Replacement components are currently on order to repair this fifth fan. The majority of the time all of the available tower fans are operated. The only time fans are shut down is if the tower is in icing conditions. There are no controls in place to provide any form of water temperature based fan control.

Cooling water is provided to the Protein Plant by six (6) vertical turbine pumps. Five (5) pumps serve the main cooling water header and the remaining pump serves the back up cooling heat exchanger for the Heat Recovery Unit. This unit provides heating of process water for the East and West Plant with waste heat.

The estimated water volume of the system is 50,000 gallons. Water treatment is a, scale inhibitor based, chemical system provided by Garratt-Callahan. This company has furnished the water treatment program from the inception of this site, even prior to the acquisition by Pilgrim's Pride Corporation. Make up water is from the city supply. A number of years ago, make up water from the waste water system was tried. The chemical treatment was not modified for the changed water conditions, and significant scaling was experienced in a short time. The use of the recycled water was discontinued immediately.

The existing tower does not have any type of filtration installed. This results in significant build up of suspended solids in the system during operation. The plant currently cleans the tower basin twice per year, removing 4-6 inches of deposits each time. 
The current loads on this tower consist of overhead condensers, heat exchangers, and air compressor cooling.

\section{Cooling Tower-Specifics}

The cooling tower consists of five (5) cells of the induced draft, cross flow design. Cells 1 and 2 were part of the original plant and little is know about the manufacturer or the date of the installation. Cells 3-5 were constructed in 1986 by BAC-Pritchard.

\section{Cells 1-2}

These are induced draft, cross flow cells with $90^{\circ}$ gear reducers (7.5:1) and single speed fans. The fans operate at $233 \mathrm{rpm}$ and are driven by an $1800 \mathrm{rpm}, 460$ volt, $75 \mathrm{hp}$ electric motors. The fans blades are fiberglass/epoxy composite with six (6) blades. The fans do not have hub seals. The fan volutes are fiberglass and approximately three (3) feet high. The fill in these cells is a wood, splash bar design furnished with the original cells. Inlet louvers are corrugated fiberglass and are in need of some repair/replacement. The cells are approximately $25^{\prime} \mathrm{x} 40^{\prime}$ and are on a concrete sump. The sump volume is estimated to be 14,400 gallons. Cooling tower make up is supplied by a 2" city water line with level control and a solenoid valve. These cells are operated 24 hours per day, 6 days per week.

The actual design data is unknown for these cells, they are similar to the additional cells (except for the fill type) and the design data is thought to be as follows:

$\begin{array}{cc}\text { Inlet water temperature } & 105^{\circ} \mathrm{F} \\ \text { Outlet water temperature } & 85^{\circ} \mathrm{F} \\ \text { Wet bulb temperature } & 78^{\circ} \mathrm{F} \\ \text { Flow rate } & 3000 \mathrm{gpm} \\ \text { Fan hp } & 2 @ 75 \\ \text { Evaporation rate } & \\ \text { Drift loss } & 2 \% \\ \end{array}$

Additional analysis of these cells predicts that the actual capacity is approximately $72 \%$ of these conditions. If the fill is changed to PVC as the other cells have, the capacity of these cells will increase to approximately $97 \%$ of the newer cells or a $25 \%$ capacity increase per cell. In addition to the fill replacement, fan assemblies and fan guards should be replaced due to age and condition.

Cells 3-5

These are induced draft, cross flow cells with $90^{\circ}$ gear reducers (7.5:1) and single speed fans. They were manufactured by BAC-Prichard and installed in 1986. The tower model number is 4458-16-3W and the serial number is 7102-86. The fans operate at $233 \mathrm{rpm}$ and are driven by an $1800 \mathrm{rpm}, 460$ volt, $75 \mathrm{hp}$ electric motors. The fans blades are fiberglass/epoxy composite with six (6) blades, Model \# APT-16B-6. The fans do have hub seals. The fan volutes are fiberglass and approximately five (5) feet high. The fill in these cells is a PVC, thin film design. The fill 
has been replaced since the original installation. The current fill has high temperature PVC material installed as the top layer and standard temperature fill below that point. Inlet louvers are corrugated fiberglass and are in need of some repair/replacement. The three cells are 24 ' -8 " $\mathrm{x}$ $60.6^{\prime}$ and are on a concrete sump. The sump volume is estimated to be 22,500 gallons. Cooling tower make up is supplied by a 2 " city water line with level control and a solenoid valve. These cells are operated 24 hours per day, 6 days per week.

The design data for these cells is as follows:

$\begin{array}{lc}\text { Inlet water temperature } & 105^{\circ} \mathrm{F} \\ \text { Outlet water temperature } & 85^{\circ} \mathrm{F} \\ \text { Wet bulb temperature } & 78^{\circ} \mathrm{F} \\ \text { Flow rate } & 3000 \mathrm{gpm} \\ \text { Fan hp } & 3 @ 75 \\ \text { Evaporation rate } & 2 \% \\ \text { Drift loss } & 0.02 \%\end{array}$

The five (5) cells are on a common sump with two (2) pump pits. The pump pit for the original two (2) cells has two (2) pumps and the pit for the additional three (3) cells had four (4) pumps.

\section{Cooling Tower-Capacity}

Cooling towers are selected for the peak conditions, including weather, that affect the performance of the towers. These are listed in the tower section and are inlet and outlet water temperature, wet bulb design temperature and the process flow rate.

Currently the process flow rate is at design and the inlet and outlet water temperatures are normally in the expected range. This appears to be the case even with the reduced capacity of cells one and two. The wet bulb design used is $2.5 \%$, this means that the design wet bulb occurs only $2.5 \%$ of the year. This also means that on the average, the wet bulb temperature will be above $78^{\circ}$ for $2.5 \%$ of the time. During these periods, the cooling tower can not meet the rated capacity.

While the cooling tower is currently satisfactory for the applied load, additional capacity would mean better condensing performance in the heat of the summer months even when the wet bulb temperature is less than design. Because cooling tower cells 1 and 2 do not have high performance fill and fans, additional capacity can be achieved by retrofitting these two (2) cells with high performance PVC fill and improving the fan performance and air flow. This modification will typically add $25-40 \%$ additional capacity to these two cells. Current analysis indicates that the most economically feasible retrofits will yield approximately $25 \%$ additional capacity. Or an overall increase of $10 \%$ for the entire cooling tower. A complete, detailed, analysis model can be done to identify additional opportunities if additional capacity is desired. (See Recommendations) 
Because the cooling tower is designed for peak weather conditions, it has capacity that is not always required. The operator can reduce energy consumption when the additional capacity is not needed by using fan employment control. This tower has opportunities to reduce fan horsepower for a considerable period each year with fan employment. Because the tower has five (5) fans, step on/off control will achieve a good energy profile at a minimal cost. Variable Speed Drives (VSD's) are not recommended here due to the extended payback for a minimal increase in savings. Use of one VSD and step control on the remaining fans is an option, but this degree of control is not considered necessary at this time.

\section{Pumps-Specifics}

The pumping system for the cooling tower consists of six (6) vertical turbine pumps. Five of the pumps are Ingersoll-Rand units with $100 \mathrm{hp}$ motors the remaining pump is a Ruhrpumpen unit with a $100 \mathrm{hp}$ motor. Each pump is rated at $3000 \mathrm{gpm}$.

Pumps 1-5 serve the cooling water header for the entire process load except heat recovery. Pump 6 serves the cooling tower water heat exchanger in the process water heat recovery unit. This heat exchanger removes any residual heat from the process load that the hot water recovery heat exchanger can not use.

All the pumps have discharge check valves and manual shutoff valves. The pump pits are equipped with inlet screens to prevent trash from entering the pump suctions.

\section{Cooling Water-Specifics}

The cooling water appears to be of fair to good quality. The plant reports no significant problems with heat exchanger fouling or lack of heat transfer capability. The most critical load appears to be the overhead condensers. The performance of these units affects the odor in the air. Currently the non-condensable vapors from these units are sent to the boilers to be burned for odor control. In the summer months, the colder the tower water, the better these condensers perform. Any improvements in the water quality will impact the performance of the condensers, particularly in the summer months when tower water temperatures rise as the wet bulb temperature rises. The only major area where improvement is expected is in suspended solids control. Cooling towers operate by inducing air flow through the fill and falling water. This causes all the airborne particles to be washed out of the air and into the cooling water. Currently this is being controlled by blow down and by cleaning the cooling tower basin twice per year. While this helps the problem, more effective methods are available and in common use in industry worldwide. The most effective, from a cost and operations standpoint is side stream media (sand) filtration. This is recommended for this cooling tower. (See Recommendations)

The current method of chemical water treatment is scale inhibitor. This indicates that the water is controlled in the scaling range and scale inhibitor is used to prevent the formation of scale on the heat transfer surfaces. 
Currently the plant is considering returning to the use of recycled waste water as makeup to the cooling tower. There are several problems associated with the use of this water. As the plant discovered in the first attempt to use this water, scaling will be much more a factor with the use of this source. An additional area to be addressed is the increased amount of suspended solids in the recycled water versus the current city water makeup. Considering that the cooling water has a high level of suspended solids washed from the air that should be addressed, this increase in makeup suspended solids will increase the problem.

\section{Load-Specifics}

Current load consists of the following equipment:

$\begin{array}{lrl}1 & 11,570 \mathrm{ft}^{2} & \text { Condenser Horizontal } \\ 1 & 5,293 \mathrm{ft}^{2} & \text { Condenser Vertical } \\ 1 & 33,000 \mathrm{ft}^{2} & \text { Evaporator Vertical } \\ 1 & & \text { Heat recovery exchanger } \\ & & \text { Various heat exchangers }\end{array}$

Due to the piping configuration, the maximum number of available pumps is operated at all times. A detailed piping study may recommend changes that would reduce the pumping requirements.

\section{Recommendations-Specifics}

1. Implement waste water reuse for cooling tower makeup

a. Facts of note

i. The cooling tower currently uses approximately 500,000 gallons of makeup water based on design and reported water consumption.

ii. The annual cost of this makeup water is: 500,000 gal/day x 6 days/week x 52 weeks/yr x $\$ 2.08 / \mathrm{K}$ gallons or $\$ 324,500 /$ year

iii. The recycled water will have a much greater amount of suspended solids than the current city water source.

iv. The $\mathrm{pH}$ of the recycled water will be much higher than the current city water source.

v. The current level of suspended solids is sufficient to cause fill fouling and the loss of performance on maximum load days and increasing this level will increase this loss of capacity.

vi. The reliability of the recycle water is not as high as the city water source

vii. Current water treatment chemical program is scale inhibitor based.

viii. A switch to bleach as a biocide is expected due to increased demand in the recycle water and the low cost of bleach.

b. Actions required

i. $\quad$ Replace damaged piping to allow recycled water use as makeup.

ii. Install side stream filtration as recommended in this report 
iii. Install a two stage level control to allow city water to be a backup source for makeup water in case of failure of the recycle supply

iv. Convert the water treatment program to a corrosion inhibitor based program

v. Install a connection to the existing on-site Sulfuric acid supply

vi. Install a bleach supply system.

vii. Install a sophisticated automatic control system for water treatment chemicals including corrosion inhibitor, bleach, and the acid feed for $\mathrm{pH}$ adjustment. This is especially important if the recycle supply is interrupted and the city water supply, with different chemical makeup, is used as a backup.

c. Estimated savings

i. The recycled water has no cost to the plant and it is estimated to be available a minimum of $75 \%$ of the time. Water savings are $\$ 324,500 \mathrm{x}$ $75 \%=\$ 243,375 /$ year

ii. Switching to a corrosion inhibitor based chemical system with $\mathrm{pH}$ adjustment will increase chemical costs by $\$ 20-30,000 / y r$.

iii. Reduced water quality of the recycled water versus the city water as makeup will increase makeup and chemical costs contributing to the increase noted in (ii).

iv. The resulting savings should be approximately $\$ 200,000 /$ year.

d. Estimated costs

i. The estimated cost for this measure is $\$ 190,000$.

2. Install discharge water temperature controlled step control for the cooling tower fans.

a. Facts of Note

i. The fan on cell 5 is out of service due to corrosion.

ii. The existing cooling system does not have discharge water temperature sensors installed

iii. Operating the cooling tower fans on an as needed basis will extend the life of the fan blades, drives, and motors

iv. Tower cell partitions are damaged and in disrepair.

b. Actions Required

i. Repair of the fan on cooling tower cell 5 is recommended as soon as practical. (reported as 'in progress')

ii. Installation of a discharge water temperature sensor(s) will be required.

iii. Repair of the cooling tower cell dividing partitions, as recommended later is this report, will be required to achieve savings by preventing air recirculation when the adjacent fan is not operating.

c. Estimated Savings

i. As the tower is designed for maximum weather and load conditions, and these conditions only exist for a short period in a year, savings are available from reducing the tower capacity when it is not needed. 
ii. Reduced capacity is achieve by shutting down fans when the capacity is not needed.

iii. Based on the average weather conditions in the area, it is estimated that the equivalent of two (2) fans will not be needed $50 \%$ of the operating year.

iv. Savings should be equal to a savings of $75 \mathrm{hp}$ for one year or $75 \mathrm{hp} \mathrm{x}$ $.746 \mathrm{~kW} / \mathrm{hp} \times 24 \mathrm{hr} /$ day $\times 16$ days/week x 52 weeks/yr $\times \$ 0.0497 / \mathrm{kW}=$ $\$ 20,067 /$ year.

v. Cell partition repair costs are not included as these repairs should be done as normal maintenance of the cooling tower.

d. Estimated Costs

i. The estimated cost to implement step control and install a discharge temperature sensor with wiring is $\$ 8,000$.

3. Replace the wood splash bar fill in cooling tower cells 1 and 2 with high performance PVC fill and upgrade the fans to maximize the benefit of the fill retrofit.

a. Facts of Note

i. Cells 1 and 2 appear to have the original wood splash bar fill from the original installation.

ii. This is the lowest performing fill available in cross flow cooling towers.

iii. Additional peak day tower capacity will have a benefit to the Protein Plant.

b. Actions Required

i. $\quad$ Replace the existing fill and hanger system with a HPVC and PVC film fill pack. Cells 3-5 have a combination of high temperature PVC (HPVC) and standard temperature PVC fill. Consider using the same combination in Cells 1 and 2 to reduce the first costs of all HPVC fill.

ii. Replace the wood drift eliminators with new PVC panel drift eliminators.

iii. Modify the hot water distribution system for the new fill pack design.

c. Estimated Savings

i. Savings are due to improved condenser performance and reduced odor control problems. Additional analysis, at the plant level, is needed to refine the savings.

d. Estimated Costs

i. Replacement of the fill is estimated to cost approximately $\$ 85,000$ per cell for a combination of HPVC and PVC fill.

ii. Replacement of the two (2) fan assemblies with Hudson APT-14H-6 assemblies is estimated to cost $\$ 5000$ each.

iii. Replacement of the fan guards with new HDG fan guards is estimated to cost approximately $\$ 3000$ each.

4. Install side stream media filtration on the cooling tower including a basin sweeping system to maximize the benefits of filtration. 
a. Facts of Note

i. The estimated volume of the system is 50-60,000 gallons

ii. The use of recycled water will increase the level of suspended solids above the existing level.

iii. The tower basin is cleaned twice annually at this time.

b. Action Required

i. Install a minimum of a $500 \mathrm{gpm}$ (565 gpm is a standard size) side stream sand filter on the cooling tower basin and a $400 \mathrm{gpm}$ (393 gpm is a standard size) filter for the make-up water.

c. Estimated Savings

i. Estimated to be approximately $\$ 200,000$ per year due the ability to use recycled water. Savings identified in recommendation 1 of this report.

ii. Improved air compressor operation due to cleaner heat exchangers and intercoolers

d. Estimated Costs

i. Estimated cost for the two sand filters is $\$ 60,000$.

ii. Estimated installation costs are approximately $50 \%$ of the equipment cost equal to $\$ 30,000$.

iii. Payback should be six (6) months or less.

5. Install fan vibration switches on all five (5) cooling tower fans

a. Facts of Note

i. All the fans had vibration switches at one time and all are out of service now.

b. Action Required

i. Install modern vibration switches at each of five (5) fans

ii. This is a significant safety issue.

c. Estimated Savings

i. Savings are in damage prevention and safety of personnel when a fan is shutdown due to vibration before failure of the fan blade, drive, or mount.

d. Estimated Costs

i. Vibration switches are approximately $\$ 380$ each for a total of $\$ 1900$ and installation should not exceed $\$ 500$ each depending on the condition of the existing wiring. Total cost estimate is $\$ 4,400$.

ii. Insure that the switches are mounted in the correct plane. If they are mounted $90^{\circ}$ out of plane, they are totally ineffective as a safety device.

\section{EVAPORATIVE CONDENSERS}

The plant site has evaporative condensers for refrigeration cooling at the East Plant, West Plant, Prepared Foods, and the Wet Pet Food Plant. 


\section{East Plant}

The East Plant has five (5) evaporative condensers EC-1 through EC-5. They appear to be in good condition and the spray water quality appears to be good. Ecolab provides the water treatment including biocide and blow down controllers. There were no reported problems in operation or capacity and none observed. The fans operate on temperature control to provide the set condensing temperature.

\section{West Plant}

The West Plant has ten (10) evaporative condensers although not all of the units were in operation during this assessment. The units were in poor to good condition with a number of very old units. The water quality appeared poor to fair. Not much is known about the operation of these units due to lack of personnel availability during the period these units were reviewed.

\section{Prepared Foods}

The Prepared Foods Plant has seven (7) evaporative condensers. These have been added over the years and are not optimally located for efficient operation. There does not appear to be an established water treatment program for the spray water. Open blow down lines were noted at four or more of the units. The estimated blow down, on a continuous basis is 50-60 gpm. This is excessive and expensive in the terms of water and sewer charges as well as water treatment chemicals if any are being used.

\section{Wet Pet Food}

The Wet Pet Food Plant has one(1) small condenser with two fans, which appears to be in good condition and is presenting no noted operational issues.

\section{Recommendations}

- Insure that all of the evaporative condensers have an adequate spray-water treatment program in place for bacteria, fouling and corrosion control.

- Reduce the blow down rate to the minimum required for good water treatment practices.

- Consider installing a common spray-water sump system for the multiple evaporative condensers. This would be especially beneficial for the Prepared Foods group of condensers.

- Consider installing side stream sand filters on the spray water to remove the airborne solids and other debris. This would be made much easier by use of a common spray water sump.

- Consider changing the fan drive belts (where applicable) to synchronous belts. This type of belt, while requiring a sheave change, has many benefits to the plant 
operation. These belts will last much longer than the typical v-belts being used on most of the units. Expected belt life is 10 years or more. They do not require retensioning for the life of the belt reducing maintenance. They will reduce the energy required by $3-5 \%$ for fan operation as an additional benefit.

- Insure that all the units have temperature control for the fans and the fans are operated on an as needed basis. This will reduce wear on the fan units and reduce the energy consumption. 